Portland State University

PDXScholar

2-16-1996

\title{
Justice Delayed: A Sixty Year Battle for Indian Fishing Sites
}

Roberta Ulrich

Portland State University

Follow this and additional works at: https://pdxscholar.library.pdx.edu/open_access_etds

Part of the History Commons

Let us know how access to this document benefits you.

Recommended Citation

Ulrich, Roberta, "Justice Delayed: A Sixty Year Battle for Indian Fishing Sites" (1996). Dissertations and Theses. Paper 5106.

https://doi.org/10.15760/etd.6982

This Thesis is brought to you for free and open access. It has been accepted for inclusion in Dissertations and Theses by an authorized administrator of PDXScholar. Please contact us if we can make this document more accessible: pdxscholar@pdx.edu. 
THESIS APPROVAL

The abstract and thesis of Roberta Ulrich for the Master of Arts degree in History were presented February 16, 1996, and accepted by the thesis committee and the department.

COMMITTEE APPROVALS:

Gordon B. Dodds, Chair

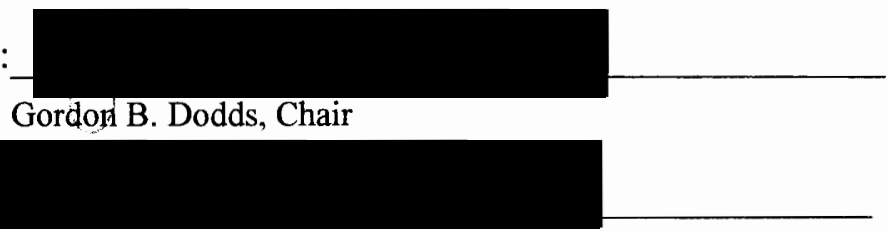

Thomas M Luckett

DEPARTMENT APPROVAL:

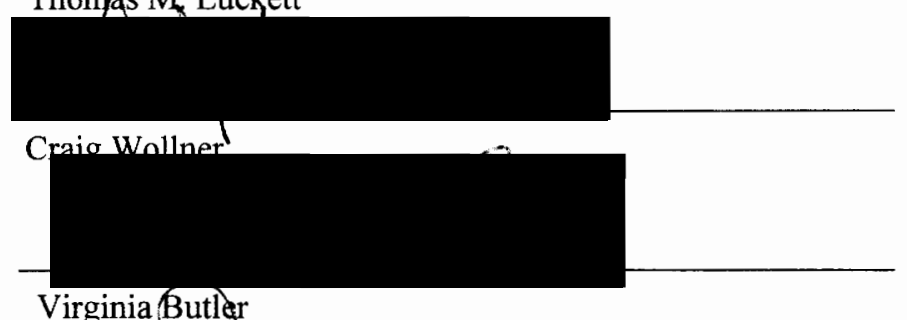

Virginia Butler

Representative of the Office of Graduate Studies

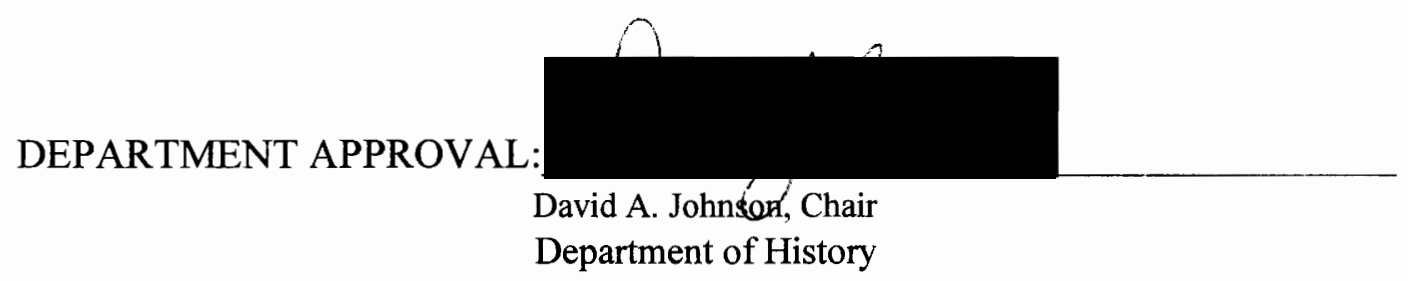

$* * * * * * * * * * * * * * * * * * * * * * * * * * * * * * * * * * * * * * * * * * * * * * *$

\section{ACCEPTED FOR PORTLAND STATE UNIVERSITY BY THE LIBRARY}

by

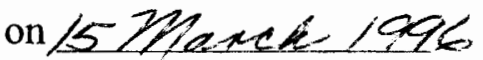




\begin{abstract}
An abstract of the thesis of Roberta Ulrich for the Master of Arts in History presented February 16, 1996.
\end{abstract}

Title: Justice Delayed: A Sixty Year Battle for Indian Fishing Sites

The Army Corps of Engineers promised in 1939 that it would provide six fishing sites totaling 400 acres for Indian fishermen to replace 40 sites that would be flooded by the pool behind Bonneville Dam on the Columbia River. The agreement with the Warm Springs, Yakima and Umatilla tribes and Columbia River Indians also included construction of living quarters, boat launches, drying sheds and sanitary facilities. Only five sites were ever acquired and drying sheds and sanitary facilities were built on only two.

This paper traces the delays through war, congressional appropriations, negotiations over sites, law suits, construction of new dams, disagreements between federal agencies and the tribes and between tribes, and slow moving federal agency processes. The U.S. Army Corps of Engineers broke ground in late 1995 on the first of 31 sites totaling 335 acres that will finally fulfill the commitment to the tribes in 2002 .

The tracing is done in the early years almost entirely through government correspondence and documents. In later years, the major sources are newspaper articles and government documents, including court files. 
The paper does not find a single cause for the extraordinary delay in fulfilling promises. Rather, it concludes that a number of events, attitudes and people had a part in creating delays at different times during the six decades. World War II caused the first major delay. Later causes included disagreements about locations, lack of appropriations, disputes over what facilities were to be included and slow government procedures. 


\section{JUSTICE DELAYED:}

A SIXTY YEAR BATTLE FOR INDIAN FISHING SITES

by

\section{ROBERTA ULRICH}

A thesis submitted in partial fulfillment of the requirements for the degree of

\section{MASTER OF ARTS \\ in \\ HISTORY}

Portland State University

1996 


\section{ACKNOWLEDGMENTS}

Following the long paper trail of the Indian in lieu fishing sites on the Columbia River would have been impossible without the help of Lynda Walker and George Miller of the U.S. Army Corps of Engineers, Les McConnell of U.S. Forest Service and Joyce Justice of the National Archives - Pacific Northwest Region, Seattle. My thanks to all of them. Special thanks to John R. Lynch, whose editing and computer expertise, patience and encouragement were essential to this project. 


\section{CONTENTS}

CHAPTER I: INTRODUCTION

CHAPTER II: THE THIRTIES - PROMISES

CHAPTER III: THE FORTIES - WAR AND RENEGOTIATION

CHAPTER IV: THE FIFTIES - HALF A LOAF, OR LESS

CHAPTER V: THE SIXTIES - STATUS QUO

CHAPTER VI: THE SEVENTIES - MORE MONEY, NO ACTION

CHAPTER VII: THE EIGHTIES - EVICTION AND TRIUMPH

CHAPTER VIII: THE NINETIES - A SHOVELFUL OF DIRT 


\section{CHAPTER I: INTRODUCTION}

Indians of the Columbia River and inland Northwest plateaus tend to begin all discussions of fish and the river with the phrase "since time immemorial." Their oral histories describe a dependence on salmon that stretches as far back as the memory of man. ${ }^{2}$ Modern archeological digs tend to confirm these tribal stories. ${ }^{3}$

When explorers Lewis and Clark floated down the Columbia in 1805 they found the Indians dining on an abundance of fish. Salmon became a staple of the travelers' diet for much of their journey along the Columbia both westward and east bound although they never developed a taste for the fish, preferring dog meat. ${ }^{4}$

But to the Indians, salmon was spiritual as well as physical food. The fish and the certainty that it would return in abundance each year sustained the tribes, serving as the mainstay of their diet and a central symbol in their religion. ${ }^{5}$ So important were the fish that the tribes gave up millions of acres of land with scarcely a battle but insisted that they retain the right to fish at their usual and accustomed places outside their reservations as well as in the rivers and streams of the lands they retained. ${ }^{6}$

So when the federal government decided in 1933 to build Bonneville Dam 150 miles from the ocean, the Indians were understandably worried. Their concern was that the dam would both drown their fishing sites and destroy the fish. They feared prophetically it turns out - that the dam would cut off the runs and the salmon would be no more. ${ }^{7}$

Few besides the Indians worried about the fish. A search of the files of The 
Oregonian and Oregon Journal, Portland's two daily newspapers, for the 1930s turns up virtually no mention of the issue except for the Oregon state fish commission's 1933 request that the dam plans include fish passage facilities. ${ }^{8}$ In response, the Corps of Engineers revised its fish passage plan to create a system of ladders, canals and lifts that added $\$ 7$ million to the cost of the dam. ${ }^{9}$ The Indians themselves do not seem initially to have realized that the pool rising behind the dam would flood their traditional fishing sites and the homes they had built there.

Not until 1937 when the closing of the gates on the dam was imminent did the issue of Indian fishing sites surface. ${ }^{10}$ Hasty negotiations followed and in 1939 the Corps of Engineers agreed to acquire six sites totaling 400 acres to replace the fishing locations along with fishing platforms and drying sheds the Indians were losing. ${ }^{11}$

Fulfilling that promise was something else. The Corps had barely begun to make good on its word when World War II intervened. Later, buying and building facilities on the sites were complicated at various time by disputes between tribes, between the Corps and the tribes, and between the Corps and the Office of Indian Affairs, by congressional inaction, by objections from the states of Oregon and Washington, by objections from non-Indian residents of the Columbia River area, by changes in the operation of Bonneville Dam, by litigation and sometimes, it appears, by sheer inertia.

The Corps actually acquired five sites totaling 40 acres by 1963 but fluctuations in the Bonneville pool and silting of the near stagnant water ruined two.

Finally, however, in 1988 Congress gave the Corps both the authority and the 
money to acquire sites and build the necessary facilities. By then, the government had built three more dams on the lower Columbia, drowning out the premier fishing site of them all - Celilo Falls - and any other fishing spots along the bank upriver to Wallula, Wash. Although the tribes took money for the loss of Celilo, the new legislation promised additional sites for Indian use in the pools of The Dalles and John Day dams. ${ }^{12}$

The wheels of bureaucracy still grind slowly. What with public hearings on site use, negotiations with the tribes and states, and further delays in Congress, the Corps finally, in November 1995, turned a symbolic shovelful of dirt marking the beginning of work on the sites.

The more than half a century between the promise and the ground breaking raises an obvious question: Why so long? There is no single or simple answer. The records reveal no master villain lurking in the bureaucracy. Instead, the answer lies in a series of larger events and issues that filled the decades from the Depression to the end of the Cold War. In addition, the Indians lacked political power. They faced hostility or indifference from their non-Indian neighbors and the states. And, at times, bureaucratic inertia simply let the issue lapse.

To the Indians, the course of action was clear from 1937 on. Their 1855 treaties promised they could continue to fish at their usual and accustomed places. If the government destroyed those sites, it owed them new ones. Government officials tended to agree, but they also became entangled in the details of land acquisition, 
appropriations and regulations. And rarely did the issue seem to have a high priority.

It certainly did not attract much public attention. A search of more than two dozen books and dozens of articles about the Columbia River, dam construction and fishing either do not mention or make a single passing reference to what came to be known as in lieu sites. For example, the Oregon Historical Quarterly alone has published dozens of articles since 1934 about Indians, dams, the Columbia and fishing. There is no reference to the sites. Even William Willingham in his two histories of the Portland District of the Army Corps of Engineers and one history of Bonneville Dam does not discuss the sites. Not until the 1960s do files of The Oregonian and Oregon Journal contain coverage of the issue. Such books as Mary Avery's 1961 Washington: A History of the Evergreen State and Anthony Netboy's 1958 Salmon of the Pacific Northwest make no mention of the sites. Only Robert Clark in his 1995 River of the West writes at length about the sites, but then only in relation to one small group of Indians led by David Sohappy. ${ }^{13}$ Donald L. Parman described the issue briefly in a chapter in the 1992 book The American Indian Past and Present, also published in Pacific Historical Review. ${ }^{14}$

Because so little has been published on the issue, the files of tribes and government agencies, mostly those of the Bureau of Indian Affairs and Portland District of the Army Corps of Engineers, serve as nearly exclusive sources about the subject until the 1960s. Some public attention began then and is reflected in newspaper coverage and congressional action. There is much more to be learned. Additional 
government files are about to become available and those may shed some light on reasons for delays during later decades.

The slow process drew little public attention because only the Indians were hurt by not having their fishing places and through most of the period they drew little sympathy from the non-Indian public. In addition, the Indians' long struggle for replacement sites took place against a backdrop of larger issues. First, the mind set of the nation, and especially the Northwest, favored development as represented by Bonneville, Grand Coulee and later Columbia River dams. Then, American entry into World War II scuttled the original plan to acquire the sites.

When the in lieu site discussions began, the Bureau of Indian Affairs - then known as the Indian Service - still acted on behalf of Indians in nearly all dealings with non-Indians. Tribes were just beginning to emerge from the debilitating effects of federal policies designed, in succession, to isolate the Indians, to destroy tribal culture and assimilate Indians into the larger society and to ignore Indians. Through the decades of the in lieu issue, federal policies continued to change from creating tribal governments to relocating reservation residents to cities and ending federal recognition of many tribes, and later to encouraging tribes to manage their own affairs. The Indians' efforts to obtain the in lieu sites also was carried on during the height of the century-old region wide battle over Indian fishing rights. This battle, which continues, reached its greatest intensity of violence and landmark legal decisions, during the 1960s and 1970s. 
In addition, the Indians often did not speak with one voice. Ancient tribal rivalries did not end when the government gathered old enemies on the same reservation. Indians who lived along the river generally did not consider themselves a part of any of the recognized tribes, remaining independent and isolated from the reservations.

The Corps, whose people were not familiar with Indian ways, appears to have faced the same frustration that plagued early Indian agents Isaac Stevens and Gen. Joel Palmer. In the 1850 s, tribal governments were not formal structures; tribes generally were an alliance of related bands, each governed largely by consensus and independent of the others. Only with the Indian Reorganization Act of 1934 did most tribes, including those who fished the Columbia River, develop structured government and begin to wrest control of their reservations and activities from the BIA.${ }^{15}$ However, the tradition of consensus remains strong even now and in the 1940s, with formal government still new, must have been even stronger. Corps personnel had little patience with the Indian style of negotiation in which everyone gets a chance to speak and is allowed to complete his argument without interruption. This frustration of Army bureaucrats allowed them to put the in lieu site issue aside, blaming the Indians' failure to agree for the delays.

But the disagreements among the Indians tended to be more about form, demanded by bureaucrats, than about the substance of replacing the sites, the goal on which nearly all the Indians agreed nearly all the time. When ground finally was 
broken at a site on the Columbia's north shore near Bonneville Dam in 1995, representatives of all the tribes and the river Indians gathered. They celebrated the belated beginning of the site work, but marked the delay in generations. Nelson Wallulatum, 69, the longtime chief of the Wasco Tribe, recalled accompanying his grandmother, Susan Palmer, to that fishing site in 1934. He also went along as she traveled the river with representatives of the Corps in 1937 to point out Indian fishing sites that would be covered by the backwater from Bonneville Dam - sites that finally will be replaced by $2002 .{ }^{16}$ 


\section{NOTES}

1. For example: U.S. Army Corps of Engineers, Final Phase Two Evaluation Report and Finding of No Significant Impact/Environmental Assessment, Columbia River Treaty Fishing Access Sites (April 1995), Technical Appendices, Technical Appendix N, Tribal Assessment of Indian Cultural Losses, prepared by Confederated Tribes of the Umatilla Indian Reservation, NU-2.

2. Ibid., NU-12-17.

3. Rick Minor, Kathryn Ann Toepel and Stephen Dow Beckham, Heritage Research Associates Report No. 83: Archeology in the Columbia Gorge (1989).

4. Gary Moulton, ed., The Journals of the Lewis and Clark Expedition, (Lincoln University of Nebraska Press, 1988, 1991) Vol. 5, 287-88 and Vol. 7, 136-165, which show the party consistently buying dogs for food despite an abundance of salmon.

5. Corps of Engineers, Phase Two Report, Appendices, NU-13,14.

6. Treaty with the Wallawalla, Cayuse Etc. 1855, Article 1; Treaty with the Yakama, 1855, Article 3; Treaty with the Nez Perces, 1855, Article 3; Treaty with the Tribes of Middle Oregon, 1855, Article 1.

7. "Bonneville Dam Worries Indians," Oregon Journal, (Portland,) Jan. 6, 1934, 1.

8. “Dam Offers Fish Problem," The Oregonian, (Portland,) Oct. 5, 1933, 3.

9. William Willingham, Power in the Wilderness (Portland: Army Corps of Engineers, 1987), 51.

10. O.L. Babcock, letter to Commissioner of Indian Affairs, Apr. 19, 1937, Box 115, Yakima Indian Agency, 1925-1967, 036.1-052, Bureau of Indian Affairs, Record Group 75, National Archives - Pacific Northwest Region, Seattle.

11. Corps of Engineers, Phase Two Report, 1-4.

12. Public Law 100-581, 100th Congress.

13. Robert Clark, River of the West (New York: HarperCollins West, 1995), 358-380.

14. Donald L. Parman, "Inconstant Advocacy: The Erosion of Indian Fishing Rights in The Pacific Northwest, 1933-1956," in The American Indian Past and Present, 
4th ed., ed. Roger L. Nichols (New York: McGraw-Hill, 1992), 245.

15. Charles F. Wilkinson, American Indians, Time and The Law, (New Haven: Yale University Press, 1987), 21.

16. Roberta Ulrich, The Oregonian, Nov. 18, 1995, 1. 


\section{CHAPTER II: THE THIRTIES - PROMISES}

\section{Prelude to Promises}

The nearly 60 -year-old issue of replacing Indian fishing sites flooded by the backwater from Bonneville Dam, has its roots in treaties between the United States and several Northwest tribes signed in 1855 and in a 1926 report by the Army Corps of Engineers and Federal Power Commission that was designated House Document 308.

The treaties were negotiated by Washington Territorial Governor Isaac I. Stevens in his role as Washington Superintendent of Indian affairs and Oregon Indian Superintendent Joel Palmer with the Walla Walla, Cayuse and Umatilla; the Yakama, ${ }^{1}$ including 14 tribes and bands; the Nez Perce, and the tribes of middle Oregon to obtain more than 60,000 square miles of Indian lands in Oregon and Washington. ${ }^{2}$ One of the inducements the government negotiators used to obtain the chiefs' signatures was a promise that they could continue fishing in their "usual and accustomed places." ${ }^{3}$ Each of the four treaties contains language similar to this in the Walla Walla document:

Provided also that the exclusive right of taking fish in the streams running through and bordering the reservation is hereby secured to said Indians, and at all other usual and accustomed stations in common with citizens of the United States, and of erecting suitable buildings for curing the same ... ${ }^{4}$

Despite the creation of the reservations far from the Columbia, some Indians continued to live along the river and hundreds of others made seasonal journeys to their traditional fishing sites. In 1889, George W. Gordon, a special Indian agent assigned to report and make recommendations on the tribes' fishing rights, counted 
more than 1,000 Indians who regularly fished at a dozen sites between Cascade Locks and the present site of McNary Dam. An undetermined number of them maintained their permanent homes along the river. ${ }^{5}$ Approximately fifty years later, in affidavits taken by Edward G. Swindell, Jr., a Department of the Interior attorney, several elderly Indians described the location and populations of Indian villages on both banks of the Columbia in the years preceding construction of Bonneville Dam. Tommy Thompson, the chief of the Wyam who was then 79 years old, said he had always lived and fished at Wyam, known to whites as Celilo. When most other Indians moved to the reservations, he remained. In addition to a few other families at Wyam, other Indians continued to live at riverbank settlements known as Tenino, Skein, Wah-pykt and Rock Creek. ${ }^{6}$ Fish was the main article of food for Indians "in the old days," he said, and remained so important to their survival that the value of their fishing rights "cannot be measured in the terms of dollars and sense of the white man ..." Similar affidavits were provided by Ellen Thompson, 74, who said she had lived her entire life along the Columbia River; William Yallup, age 75, who lived at Rock Creek; Willie John Culpus, 48, also a resident of Rock Creek; and Martin Speedis, 74, of Spearfish. ${ }^{8}$ In House Document 308 the Corps of Engineers listed 10 river basins, including the Columbia, that were worthy of detailed investigation to determine "general plans for the most efficient development of such streams for the purposes of navigation ... in combination with the most efficient development of the potential water power, the control of floods and the needs of irrigation." In 1927 Congress ordered the Corps to 
make the studies and in 1931 the Corps presented a detailed plan for 10 dams on the Columbia, beginning with Bonneville 30 miles east of Portland and concluding with Grand Coulee 150 river miles from the Canadian border. With the country deep into the Depression, Franklin D. Roosevelt promised during his 1932 campaign for the presidency that he would build both Bonneville and Grand Coulee. ${ }^{9}$ By the fall of 1933, preliminary work was under way for Bonneville Dam. ${ }^{10}$

The Indians who lived and fished along the river were quick to express their concern "over what is going to happen to the salmon run when the Bonneville Dam is built." The Oregon Journal reported January 6, 1934, "Chief Tommy Thompson of Celilo called upon United States Attorney Donough today and propounded that question to him." In its brief story, the Journal reported that the Indians claimed the dam "not only will submerge the long-established fishing grounds but will interfere with the run of salmon, especially the return of the young to the ocean."11 In reality, it would take construction of another dam, The Dalles, 20 years later to submerge Thompson's fishing grounds at Celilo. While non-Indian fishing interests and the Corps pinned their hopes for the salmon on fish ladders and other devices, the concern over Indian fishing sites disappeared from the two Portland newspapers. ${ }^{12}$ There is no other mention through the 1930 s.

Files of the Bureau of Indian Affairs and Corps of Engineers show, however, that the two agencies became aware of a potential Indian claim for loss of their fishing places in the spring of 1937 . Two documents dated in June of 1937 discuss the issue 
raised by the superintendent of the Umatilla Indian Reservation, O.L. Babcock.

Babcock's letter that precipitated the correspondence has not appeared in any files available through the National Archives Pacific Northwest Region in Seattle or the Portland District of the Corps of Engineers. However, his suggestion that the Indians might have a claim against the government for loss of their fishing sites appears to have caused some consternation in Washington although it took nearly two months for an official reaction.

The first of the two documents in the BIA files is a memorandum to the Commissioner of Indian Affairs from the agency's acting solicitor, Frederic L. Kirgis, dated June 15, 1937. In that memo, Kirgis states:

In a letter to you dated April 19 the Superintendent of the Umatilla Indian Agency reports that the filling of the lake above Bonneville Dam now under construction by the Federal Government will drown out many of the "usual and accustomed fishing places" of the Indians who have made their living by fishing along the Columbia River. He requests that an investigator be detailed to examine the fishing activities of the Indians along that river in order to ascertain the number and value of the fishing places which will be destroyed and to gather data relative to the application of the "usual and accustomed fishing places" at higher elevation along the river.

The memo states that Babcock urged immediate action because 1937 would be the last fishing season before the water rose behind the dam and "it will be impossible to gather information after the lake is filled." The questions raised by Babcock were referred to "Mr. Cohen" in the solicitor's office (presumably Felix Cohen who became the nation's premier expert on Indian law) but Cohen was absent, leaving the matter to Kirgis. Specifically, the lawyers were asked to consider the "rights of the Indians and 
their practical enforcement."

Kirgis responded, "This letter presents two distinct problems: First, as to the right of the Indians to compensation for the destruction of their fishing places and, second, as to the possibility of transferring their special privileges in the existing fishing places to other possible fishing places." The "problems" probably extend to Indians of the Yakima and Fort Lapwai (Nez Perce) reservations, as well, Kirgis said, since their treaties contain similar language reserving fishing rights. There followed a lengthy legal analysis, including the citation of several Supreme Court rulings. In essence, Kirgis concluded that the Indians had a proprietary right in fishing at their usual places, that the loss of those usual places resulted directly from government action in building the dam and that the Indians, therefore, were entitled to compensation. However, the fact that the dam was being built "in aid of navigation" would make it unnecessary for the government to compensate the Indians for their loss, he said, unless their "fishing rights can be shown to be on a different plane from other private property rights." Supreme Court rulings and the treaties made the Indian claim stronger than usual property rights, he said. He advised the commissioner:

From the foregoing, I conclude that the Indians have a possible claim for compensation for the destruction of fishing places by the Bonneville Dam. While the claim is not certain because of the fact that the action by the United States is taken in the aid of navigation, there is, however, in my opinion, sufficient reasonable ground for a claim as to make it imperative to protect the interests of the Indians in all possible ways.

Kirgis suggested that a settlement might be negotiated with the Public Works Administration, which was the source of initial funding for construction of Bonneville 
Dam, and the Corps. Any compensation would have to go to the tribes, not individual Indians, he said. "There is no possibility of transferring by any action of the Federal Government the special fishing privileges of the Indians from the existing places covered by the treaty to new areas," Kirgis wrote. Only the states now could grant new fishing rights, he said, and he considered it unlikely either Oregon or Washington would be interested in granting fishing privileges to Indians. However, he suggested that the Indians might find other fishing spots on the river and that should be considered in determining any damages from loss of the old sites. ${ }^{13}$

Ten years after the Northwest treaties were signed, the superintendent of the Warm Springs Reservation developed a pass system for Indians leaving the reservation and several Indians signed it. Two years later, the U.S. Senate ratified a document, which tribal members said they had never seen, concerning the Indians' off-reservation rights. An investigation that went on for nearly 30 years concluded that the document ratified in 1867 - the pass system - had not been negotiated with the tribes and was not a treaty. Congress has ignored the document and at least four Supreme Court rulings uphold rights contained in the 1855 treaty. ${ }^{14}$ However, the court rulings all were after 1937 and Kirgis apparently believed the "treaty" was a binding document. Citing it, he said the government paid the Warm Springs Indians $\$ 3,500$ to relinquish their fishing rights and they therefor had no claim for lost fishing sites. ${ }^{15}$

\section{Laying The Groundwork}

Kirgis's legal opinion brought action quickly, in bureaucratic terms, from the 
commissioner's office. On June 26, 1937, William Zimmerman, Jr., assistant commissioner of Indian affairs, wrote to Kenneth R.L. Simmons, a bureau attorney in Billings, Mont., requesting him to begin work on the site survey "at your early convenience," a polite way of ordering him to do it now. He also suggested that he call on other agencies and Indian bureau personnel to help. Zimmerman wrote:

We have been advised by the Superintendent of the Umatilla Indian Agency, Oregon, that the construction of Bonneville Dam will cause the flooding of a number of the usual and accustomed fishing places of the Indians on the Columbia River. The treaties with the Indians of the Coeur d'Alene [sic], Yakima and Umatilla Reservations provide that the Indians shall have the right of taking fish in all usual and accustomed places in common with citizens of the territory, and of erecting temporary buildings for curing fish. In view of the provisions of the treaties, it is possible that the Indians of the above mentioned reservations may have a claim against the Government if the construction of the Bonneville Dam operates to deprive them of the fishing privileges they have previously enjoyed along the Columbia River.

The situation requires careful investigation and the submission of a complete report in order that the Office may be in a position to initiate action in the protection of the interests of the Indians. ${ }^{16}$

Zimmerman asked Simmons to go to the Umatilla Reservation to confer with the superintendent and for the purpose of "assuming the principal responsibility in conducting the investigation ..." ${ }^{17}$ Indicating that he intended for the investigation to be thorough, Zimmerman told Simmons also to confer with the superintendents of the Yakima and Warm Springs agencies, the Indian Office's regional forester in Spokane and the federal Bureau of Fisheries. The forester might provide Simmons with some Indian Service staff members to help "in assembling information essential to an appraisal of the damages which will be sustained by the Indians" and the regional 
fisheries director "is fully acquainted with the fishing industry on the Columbia River." 18

Babcock did not wait for his superiors in Washington to order or take action. In a memo, apparently for his own records, dated June 28,1937 , he recounted the steps he had already taken. On June 24 , he wrote, "I went to Underwood, Washington, to meet with the Cascade Indians on matters pertaining to the loss of fishing stations, occasioned by the filling of Bonneville Dam." He added, "It was agreed at that time that the Cascades would select a committee of three, and the Yakima, Warm Springs and Umatillas would also select a committee of three, and the twelve committeemen would proceed to list and describe the various fishing places which would be destroyed." (Note that Babcock includes the Warm Springs. The Cascades were people who lived along the river, nominally assigned to the reservations but generally considering themselves apart. Throughout the first two decades of the fishing sites issue the "river Indians" were treated as a separate entity.)

Babcock also reported he went from Underwood to Portland, where he contacted Col. Thomas Robins, North Pacific Division Engineer of the U.S. Army Engineers “with relation to the Bonneville Dam construction's liability for damages to the Indians for the destruction of the fishing places." Robins, Babcock said, did not concede any liability but offered a power boat to take the Indian committee to visit the sites. ${ }^{19}$

By September 13, Pat Gray of the Indian bureau's Spokane Forestry Office was working along the river taking affidavits from Indian fishing people. The Indian Office 
telegraphed authorization to pay both the notary fees and an interpreter for the project since many of the Indians spoke little or no English. The interpreter, William Switzler, was to receive $\$ 5$ a day, according to F.R. Anderson, clerk in charge of the Umatilla Indian Agency. He cited no amount for notary fees but the Umatilla and Yakima Indian Agencies already were negotiating about sharing costs of the work. ${ }^{20}$

Simmons, too, responded quickly. Back in Billings after his survey of the Columbia, he wrote a preliminary report on November 23 just a week before the gates were to close on Bonneville Dam, to begin filling the pool. Much of Simmons's 13 page letter to the Commissioner of Indian Affairs was excerpts from histories of Columbia River fishing. He also indicated, however, that he had done a considerable amount of work on the present issue.

First, he concluded that it was impossible to determine "what the ultimate damage may or may not be" to the Indians' fishing rights. "The opinion of affected interests along the Columbia River is still equally divided as to whether or not the salmon will go over the dam by way of the fish ladders and fish elevators ...," he wrote. "The experts are considerably worried about the salmon after they pass the dam due to the change in river current ... By the end of the first salmon run next spring the major speculation should end."

Simmons also said he would limit any claims to the Yakima and Umatilla Tribes. He again raised the issue of the Warm Springs' 1865 treaty, although he noted that the tribes considered the document fraudulent and were suing for compensation 
for the fishing rights it extinguished.

On July 26, Simmons went with Indians knowledgeable about the fishing sites and a photographer on a boat trip from The Dalles to Bonneville. A picture was taken of each site and Simmons said a second picture of each location would be taken from the same spot in the spring or summer of 1938 after the dam was in operation. Simmons considered the photos "highly important" as evidence in any claim. He said information obtained from the Army Engineers indicated that Celilo, the premier site, would not be affected. He referred to estimates of the Indian fishermen's income and value of the fish they kept for family food, but the letter contained none of those figures. Most of the affidavits came from the Wasco and Middle Oregon Tribes, Simmons said, because the Yakima and Umatilla Indians did most of their fishing farther upstream. Simmons found it unfortunate that no records of the value of subsistence fishing or of the catch from each site had been kept. He asked the Yakima and Umatilla superintendents to interview each tribal fisherman to learn the value of both the fish he sold and the fish his family ate. "A similar record will be kept in 1938," he said. "Then a comparison can be made and some reasonable estimate of the resulting damages reached." Looking ahead, he also asked the superintendents to get similar information about Celilo.

Simmons also met with the Yakima and Umatilla Tribes. "Members of the two tribes unanimously went on record as favoring the purchase of new fishing sites by the United States with the amount of moneys allowed these tribes by the United States for 
damages rather than the payment of money to the tribes," he reported. The lawyer's explanation was that only 10 percent of the tribal members fished and these individuals retained all the money from sale of the fish while payment to the tribes would mean prorated payments to all tribal members.

He concluded:

As indicated it is impossible at this time to estimate either the ultimate damage or the temporary damage which will result after December 1, 1937, when the dam is placed in actual operation. After a comparison is made of the value of the catch in 1938 with the value of the catch in 1937 it may be possible to submit a somewhat complete report, providing there is no interference with the run of the salmon by the Bonneville Dam. ${ }^{21}$

The next step in resolving the issue came almost a year later. During several conferences along the river in October 1938 there was discussion of the possibility that the Army would buy replacement sites. John Herrick, assistant to the Commissioner of Indian Affairs, outlined the content of these discussions in a letter November 21, 1938, to Col. John C. H. Lee, the Division Engineer at Portland, telling him the Indian Office was prepared to recommend to the Indians that they enter into negotiations with the War Department over damages to their fishing places. "It is our feeling that it will be mutually advantageous if an agreement can be reached out of court," Herrick wrote. He added, "Naturally our recommendations must be confined to past and present damages. We could not approve any agreement which might jeopardize the Indians' right to seek compensation for possible damages done in the future." He also said the issue of damages should be confined to the fishing sites, leaving the question of whether the fish run itself had been diminished for future discussions. 
Significantly, in light of developments during the 1960s and 1970s, Herrick said the discussions at meetings at Celilo and The Dalles October 28 and at later conferences involved a recommendation that the War Department "purchase certain lands, construct the improvements necessary for an Indian settlement, and construct improvements at Indian fishing stations.” This, he said, should make the Indians willing to release the department from damage claims for sites that had been submerged or lost their usefulness as a result of the dam. Herrick said Simmons would be in Portland during December and would call on Lee to discuss the matter. He said Lee and Simmons should "decide at what point the representatives of the Indians should be brought into the picture."22 This last statement is typical of the attitude of condescension which pervades particularly the early correspondence on the sites. At times, the Indians seemed almost an afterthought.

\section{Staking Claims}

Simmons once more acted quickly. On December 9, he reported to Herrick that he had met in Portland with Lee and other officers of the Corps. The Corps, he said, was willing to concede that any sites destroyed or damaged by the rising waters behind the dam were usual and accustomed sites as defined in the treaties. However, Lee said the Corps could not take any action until the damage was called to the attention of the War Department in writing by the tribes through the superintendents of the Yakima and Umatilla agencies. "It was decided that superintendents Johnson and Babcock with the aid of Superintendent Elliott would have each affected tribe select representatives 
who would determine the nature of the damages suffered to each site or fishing station either by inundation, partial or complete, or by change in the river current," he wrote. The photos he had ordered the previous year would provide the evidence. "No money value is to be estimated or claimed," Simmons said. The physical damage alone and a request to discuss the claims "with an idea of possible compromise" were to be presented to the War Department. ${ }^{23}$ The superintendents were M.A. Johnson of the Yakima Agency, Babcock of Umatilla and J.W. Elliott of Warm Springs.

The issue soon rose to high departmental levels in Washington. On January 26, 1939, Oscar L. Chapman, Assistant Secretary of the Interior, told Simmons the matter had been discussed at a recent conference of representatives of the Justice, War and Interior departments. The conclusion of that meeting, Chapman said, was that the most satisfactory way of resolving at least part of "this complicated problem" was for the War Department to turn over a site or sites to the Indians in lieu of those destroyed. He told Simmons to try to accomplish a solution to that phase of the problem but said determining damages to the fish life would require years. ${ }^{24}$

The Indians took only a few weeks to develop their claims. On January 28, Johnson, the Yakima Agency, superintendent, wrote to Don E. Meldrum, senior land appraiser for the Corps at Bonneville, describing the Indians as "anxious" to enter negotiations. He enclosed the claim, including two lists, one of seven sites and another of 16 sites lost to the Bonneville pool. ${ }^{25}$

The Indians' claim was directed to "Col. Weaver in charge of Bonneville Dam 
construction" (actually, Maj. Theron D. Weaver). It was signed by Thomas Yallup, Alex Saluskin, Philip Olney and Dave Miller for the Yakimas; George Redhawk and Allen Patawa, along with Superintendent O.L. Babcock, for the Umatilla; and Isaac McKinley, Frank Winishut, Jerry Brunoe and Robert Smith for the Warm Springs. The claim was for the loss of fishing sites and camps. "This loss was due to flooding of our ancient and accustomed fishing sites at the points mentioned due to the construction of Bonneville Dam," the claim states. "We have duly considered these losses in our tribal meetings and it is the opinion of our people that an effort should be made to have the United States Government, through your department, take steps to provide us with additional fishing sites and facilities." They said their attitude had been "very appropriately expressed" by Frank Weenashet (probably Winishut), a Warm Springs fisherman, at a recent meeting:

(He) urged all of the Indians to stand together in this matter and stated that the Indians did not want money for their fishing sites because the Indian did not know how to handle money. These fishing sites represented food and a means of living for the Indian. They wanted only similar sites or facilities for getting this food in exchange for the ones that had been lost. He stated they had confidence in the good will of the War Department to deal fairly with the Indians. He pointed out that in many times of trouble the Indians had gladly assisted the War Department and the Army of this country. They had even shed blood and died when their country needed them. Now when the Indians' means of living and food supply was threatened he felt sure that this same War Department would work with them in a cooperative and understanding way in an attempt to restore these losses.

The shorter list of fishing sites, on the Washington side of the river, included the mouth of Wind River, mouth of Little White Salmon River, mouth of White Salmon River, mouth of the Klickitat River, below the mouth of Celilo Canal near Big Eddy, 
Beaver Creek west of Underwood and "several other ancient and accustomed fishing places used at various stages of the water and shown on the photographs when the Indian delegation made its first boat trip from Big Eddy to Bonneville.” The longer list, on islands and on the Oregon shore, included the mouth of Eagle Creek, Bradford Island; the Cascades, mouth of Herman Creek, mouth of Rock Creek, Mitchell Point, Hood River, Chenoweth Creek, 11/2 miles downstream from The Dalles, The Dalles, mouth of Three Mile Creek, an unnamed island, North Pine Island, Choke Cherry "above Seufert's cannery," Broken Finger below the mouth of Celilo Canal and "locations between Tenino and the mouth of Celilo Canal."

Discussions continued through January although the issue was complicated by a condemnation suit the government filed against Northwestern Power Co. in U.S. District Court in Tacoma. Because the suit involved compensation to the company for property flooded in the Bonneville pool, 40 Indians, acting as individuals, filed to intervene in the case presumably to bolster their own case for compensation. The judge allowed the Indians to enter the case, but in doing so on January 9,1939 , he also ordered a 60 -day delay requested by the government. According to a report by Weaver, Bonneville District Engineer for the Corps of Engineers, the request for a delay was made because the Attorney General needed time to figure out how to handle the Indians' intervention and hoped the Corps would reach agreement with the tribes before trial of the condemnation action. Writing on March 7, Weaver noted wryly, "To date this office is not informed of any action taken by the Attorney General since 
January 9, 1939."26

Meanwhile, in response to a request from the Army, Johnson, superintendent of the Yakima Indian Agency, convened a meeting of tribal delegates at The Dalles to determine how many fishing stations they wanted the Corps to build as replacements for the lost sites. G.W. Shoemaker, a civilian from the Corps of Engineers attended. ${ }^{27}$ Minutes of the meeting record a litany of losses and proposals for construction of several full villages. The Army had asked for more details on the sites listed in the Indians' claim and on the number of Indians affected, and they responded in detail. Each location provided spots for 20 to 200 fishermen, they said. Although some of the places near Lone Pine close to The Dalles were still usable, the rising water had done considerable damage, John Polk reported. Henry Charley of Hood River and Alex Saluskin, a Yakima, painted the bleakest picture. For the past two years, Charley said, Indians on the north side of the river had been unable to catch enough fish for their own food. Saluskin said he remembered catching about 1,500 pounds of fish a day in 1926. In 1938 he fished for three days and did not catch a fish.

Asked to express an opinion about what he had heard, Shoemaker, said he was only an observer. He suggested the Indians put the information in the form of a resolution and attach it to their claim. He said the Army would ask for another meeting after it had an opportunity to consider their claim. Thomas Yallup of the Yakima countered that the War Department should make an offer. ${ }^{28}$

At the same meeting, the Warm Springs delegates presented a written list of 
proposed site improvements to replace those they lost. The list included sites on four tributaries - Eagle, Herman and Lindsey creeks and Hood River. They also suggested that shore lands from Lone Pine to the mouth of Celilo Canal and all fisheries not affected by slack water between the mouth of the Celilo Canal and Tenino be acquired and set aside for Indian use. And they asked for construction of fishing villages in the vicinity of Lone Pine, Tenino and Celilo. Perhaps indicating their skepticism of government promises, the Warm Springs list described the suggested Lone Pine site as "the old Indian village of Ali Ali, formerly occupied by Old Smikes." Old Smikes, the document stated, had been told he must move from his home near Celilo when the Celilo Canal was being built in the early 1900s, and that a new village would be developed for him above Big Eddy. "Smikes moved," the Warm Springs report said, "but the promise of a new location was not kept."29

Major Weaver, in his March 7 report to the Division Engineer on negotiations with the Indians, passed along the results of the February 28 meeting. He wrote: "The consensus of opinion among the Indian delegates seemed to agree with the suggestions offered by Mr. J.W. Elliott (Superintendent of the Warm Springs Indian Agency), which requested the War Department to furnish camp sites at various locations adjacent to or in the immediate vicinity of the usual and accustomed fishing stations flooded by the backwater above the Bonneville Dam, with the understanding that the Indians would provide their own fishing facilities." Indicating impatience with the Indian style of meeting, Weaver made two recommendations: that the War Department 
interpret the Indians' claim to apply to all Indians and their descendants who fished the Bonneville pool area from time immemorial. And that instead of the 16 sites listed in the claim "sites be acquired and suitable quarters and drying sheds be constructed" at seven sites. He included the Warm Springs despite an 1865 treaty, which he said the Indians claimed was fraudulent. "The Indian tribes have so intermarried that today there is no longer any pure stock of any tribe," he added.

He listed the sites as: the right bank of the Columbia River between Rock Creek and Cascade Rapids, and at the mouth of Herman Creek, both in Hood River County, Ore.; Wind River and Little White Salmon River, both in Skamania County, Wash.; Big White Salmon River in Klickitat County, Wash., and in the vicinity of Five Mile Rapids on both sides of the river. He said if his recommendation was "approved in principle, negotiations with the Indians will be continued in order to determine the area needed and estimated cost of essential improvements required at each station,"30

Two letters in BIA files, both written by Yakima Agency Superintendent Johnson and dated April 13, 1939, indicate that Meldrum, head of the Corps of Engineers land section at Bonneville, sent Weaver's seven-site recommendation to Johnson on April 10. Johnson's letters, one to Meldrum and the other to Warm Springs Superintendent Elliott, acknowledge plans for a meeting on April 18 to discuss the Army's proposal. ${ }^{31}$

\section{Let The Talks Begin}

With both the tribes and the Army having laid out their positions, negotiations 
began. On May 23, delegations from the Warm Springs, Yakima and Umatilla Tribes and the Columbia River visited the sites proposed by Major Weaver. The following day, both the Warm Springs and Yakima Tribes responded to the Army plan with general approval but made suggestions for changes or alternatives for several of the sites.

In the May 24 letter to Meldrum, the Warm Springs delegation approved all but two of the sites. The letter states no reason for rejecting the site between Rock Creek and Cascade Rapids, but says the North Pine Island site "is too far removed from desirable fishing grounds" and "is not a suitable location for the drying of fish." In place of the Pine Island site, the Warm Springs asked that the Army substitute "a new site in the vicinity of No. 3 fish wheel, directly opposite your Big Eddy Station, and also a location at Tenino." Both sites, they said, had been shown to Mr. Shoemaker of the Army. "If these two new locations can be acquired and developed for the use of Indian fishermen, this delegation will approve the offer you have made to cover damages to fishing locations along the river resulting from Bonneville dam," the letter stated. The delegates also made two things clear to the Army: the sites were only limited compensation and the Indians expected the Corps to improve the sites. "We wish it understood, however, very definitely, that a settlement for damages on the basis of your letter of April 10, 1939, to Mr. Johnson, and of this letter, shall cover only damages to Indian fishing sites flooded and otherwise destroyed by water impounded by the Bonneville Dam, and shall in no matter effect [sic] any future claim for 
damages which may in time become apparent on account of interference with the migration of Salmon, or which may result from future developments along the Columbia River by the Federal Government," the letter stated. The letter also said that on their visit to the sites Shoemaker had "explained that efforts would be made to secure adequate camping grounds at these locations and that water and sanitary facilities would be constructed ... and the properties would be permanently available for the use and benefit of the Indians who customarily fish at and in the vicinity of these sites." No signatures appear on the file copy of the letter but it was written over the names of Frank Winishut, Jerry Brunoe and Isaac McKinley. ${ }^{32}$

Like the Warm Springs, the Yakima delegation made no mention of the site between Rock Creek and Cascade Rapids and had some suggested changes regarding others. The Yakima asked for a site at Tenino rather than Pine Island. At the Big Eddy site, the Yakima letter said the Army should include in its purchase a tract within the site owned by Seufert Brothers, a major fish cannery, and should build an improved road from the site to the Spearfish Indian village. The letter expressed doubt that the Big White Salmon site had enough camping space and suggested that material removed in making a terrace there be used for a fill in a water-covered area next to the highway and bridge. If the Army would make those changes, the letter said, "we hereby give our tentative approval to your proposal; this approval subject, of course, to the final approved by our tribal council." The Yakima, too, were explicit about the extent of compensation: "It is also our understanding that these sites are to be 
purchased for the sole purpose of compensating the Indians for the loss of former fishing and camping sites and that this settlement will in no way be construed as a settlement for any future loss to the Indians from the run of fish in the Columbia River due to the construction of Bonneville Dam." The BIA file copy of the letter contained no signatures but was written over the names of Philip Olney, David Miller, Thomas Yallup and Alex Saluskin. ${ }^{33}$

The files show no response from the Umatilla Tribes or Cascade Indians until a meeting of the Celilo Fish Committee on June 7. At that meeting, Umatilla Indian Agency Superintendent Babcock reported that the Umatilla delegation approved all the sites except Lone Pine and asked that a site at Tenino or "Alla Alla" - apparently the Old Smikes site mentioned earlier as Ali Ali - be substituted. Sally Ann Joyce, speaking for the Cascade Indians, had more ambitious goals. She said her people wanted the government to purchase a strip of land on each side of the river beginning a half mile below the dam and extending five miles downstream. There were many more fishing sites destroyed upstream from the dam, she said, but if the Army would buy the two strips and prevent interference from white men there "then we Cascade Indians will agree to preserve these grounds as long as we live under the sun, to remain as during the time of our forefathers who once owned them, with lasting peace and harmony." Others of the river Indians asked for equally extensive site acquisition. Chief Tommy Thompson of the Mid-Columbia River People asked, by legal description, for most of the land along the Celilo Canal except for highway and 
railroad rights of way. Willie Yallup and Martin Spedis [sic], representing Indians on the north shore of the river, also asked for stretches of shore land. ${ }^{34}$

The proposals from Joyce, Thompson, Yallup and Spedis were sent to Yakima Agency Superintendent Johnson on June 9 in separate letters. Seven others added their names to letters of support for the requests from the river people. ${ }^{35}$ There is no evidence in the files that any of these extended requests were considered despite a rather remarkable plea on their behalf by an agent only recently appointed to serve in a new Indian Service substation at The Dalles.

The new "field aid," as he signed himself, was C.G. Davis. In a letter to Yakima Superintendent Johnson on June 10, 1939, Davis laid out the case for the river Indians as expressed in the June 7 meeting. "Inasmuch as Celilo Fish Committee has no jurisdiction as to disposition of War Department proposition, the different chiefs in attendance arranged a meeting in the field office at The Dalles to give vent to their pent up feelings regarding the whole situation of compensation for lost sites," Davis wrote. "They feel, and I personally see their point of view, that if certain places number seven in all are transferred to the Interior Dept. for exclusive use of Indians, where they can fish without interference or molestation by white man [sic], where they may use set nets or gill nets or dip or bag nets at their discretion, without license or tax, where in fact a veritable paradise will exist, then it would be unfair for other locations to be not likewise dealt with." During this period, despite numerous court decisions in the Indians' favor, there were continuing efforts - often successful - to 
force them to acquire state fishing licenses, to bar them from fishing sites and to restrict both their fishing seasons and the equipment they used.

Davis, in his short time in the post, appears to have acquired a remarkable understanding of the Indians. He wrote:

The Indians have certain understandings among themselves where each one has a habit of fishing - this is true more as to Indians who make their abode on the river the year around. Their pride, or something, doesn't permit them to be moved around by the white man and they feel that some tribes of River Indians will, therefore, have more privileges than others. They feel that residents of the River country haven't properly been represented in dealings with the War Department - that the Yakimas, the Warm Springs and the Umatillas have been allowed to send in reports to War Department as to what those people want, but that the Indians from Rock Creek, Celilo, Wishram, Spearfish, Hood River, Underwood, etc. have had no chance to voice their wishes in the matter. They feel that those districts that are not accorded legal ownership of grounds will be discriminated against, or possibly evicted, by the white people because the whites cannot do anything to them at the seven owned spots and will take it out on them where they can ...

Davis recognized that the Indians' proposal was impractical. He recommended to Johnson that he write to each of those who submitted the June 9 claims "explaining frankly that the War Department couldn't buy the whole river for them" and that their claims will be considered. "I would also recommend that very careful and deliberate consideration be given their requests, from an administrative point of view, as I sincerely believe their contention has high merit," Davis added. He explained:

After all, these River Indians only desire what we all contend to be their real rights. They are fisher folk, depending principally on catch of fish for their food and the money received from sale of fish for their living expenses other than food. They only want to be allowed to live in their own peaceful way and not be harassed by malicious whites and breeds. They are peaceful, genial and as a rule honest. They dislike to have outsiders come in and deprive them of their happiness and food supply. They believe that Reservation Indians should not 
crowd them out because the Reservation lands that they own bring them an income and the River dwellers have no such income.

Davis was concerned that his boss might think he was "over solicitous" for the River people. "The fact is," he said, "I am really getting to like them and want you, as their Superintendent, to get their view points and kind of see their side of things." ${ }^{.36}$

\section{Agreement - Almost Too Easy}

There is no indication that Johnson did anything with either the requests from the River Indians or Davis' recommendation. When Major Weaver made his final proposal on July 12 , he directed it to Johnson but said it also was his reply to reports of the Yakima, Warm Springs and Umatilla delegates dated May 24, May 24 and June

$5 .{ }^{37}$ In this final proposal, Weaver listed six sites instead of the original seven:

- Tenino, "an irregularly shaped parcel of land lying between the Columbia River Highway and the Celilo Canal, situated partly on government land and land owned by Seufert Bros. in the vicinity of the Five Mile Lock of the Dalles-Celilo Canal." Water for domestic purposes was available from an existing system on the government land.

- Big Eddy on Washington state lands. The government would acquire all the state owned lands within a section in Klickitat County, Wash. Domestic water was available from a spring on the site.

- $\quad$ Big White Salmon at Underwood, Wash. The government would acquire a stretch of land on the west bank of the Big White Salmon River between the Underwood Hill highway and the river. The acquisition would include "all the houses which are at present located thereon." The site was to be included in the condemnation proceedings pending against Northwest Electric Co., which owned the land. The government would develop a domestic water supply, probably a well.

- $\quad$ Little White Salmon. Weaver said the site undoubtedly would be acquired through condemnation and, because "there are other matters involved," the action probably would result in more land for the Indians than the tract they 
had looked at the year before. The government would develop a domestic water supply.

- Wind River. The government would acquire 20 or more acres along the Bonneville-Coulee power transmission line right of way. A spring on the site would furnish domestic water.

- Herman Creek. The site was different from, but more accessible and more convenient to fishing sites, than the site first proposed at Herman Creek. It included a portion of state fish hatchery property and an adjacent five-acre tract beside the Oregon-Washington Railroad and Navigation Co. tracks. Domestic water supplies were available from a spring or a well.

- The government would build an incinerator and sanitary facilities at each site except Herman Creek, where sanitary facilities already existed.

Weaver said the proposal was to be submitted to the tribal councils for approval "in order that this office may proceed with a definite request to higher authority to negotiate and purchase or condemn the above sites for use by the Indians in replacement of ancient and accustomed fishing locations destroyed and flooded by the construction of the Bonneville Dam." ${ }^{38}$

Only the Yakima resolution accepting Weaver's July 12 proposal appears in the files, but on August 17, Johnson reported to the commissioner of Indian affairs that all three tribal councils had accepted it. "These negotiations have necessarily been rather long and tedious," he wrote, "because of the different tribes and bands of Indians involved and a natural inclination on the part of the Indians to be very careful in negotiations on any matter as important to them as their fishing rights along the Columbia River." Johnson told the commissioner he considered the settlement fair, but he cautioned, "This settlement should not, however, in any way be interpreted as a 
settlement for the loss to the run of fish which may develop in later years due to the construction of Bonneville Dam." He asked the commissioner "to consider this matter carefully with the suggestion that definite instructions be issued as to further procedure." ${ }^{.39}$ The Yakima resolution of acceptance dated August 9 was "conditioned upon the understanding that this settlement is to cover only damages to Indian fishing sites" and would not affect future claims for loss of the fish resulting from construction of either Bonneville Dam or future projects. ${ }^{40}$

By the end of the month, the Corps of Engineers was looking at the land to be acquired. On August 30, 1939, Meldrum, the Corps' land officer, wrote Johnson acknowledging receipt of the tribal resolutions and reported that his office was appraising several of the parcels of land. As soon as the appraisals were finished, the matter would be submitted to the Chief of Engineers for final approval, Meldrum said. $^{41}$

Meanwhile, a man named J.M. Jessup of Cook, Wash., was pushing Davis, the Indian Service agent at The Dalles, to get the Corps to buy all his land at the mouth of the Little White Salmon, instead of just a portion of it. In letters to Johnson, Davis indicated his frustration with Jessup. "He seemed to want to TALK more than anything else," Davis wrote on June 28 after a visit in which Jessup harangued him for two hours. "He is rather advanced in years and his mind seems to be wandering a bit. ${ }^{\prime 42}$ Finally, on September 21, 1939, Davis wrote Jessup a warning letter reminding him of the Indians' right to fish at the property and requesting him to "refrain from 
further molestation of Indians who have a right to travel over a definitely marked road to these grounds. ${ }^{, 43}$

Davis also attended a hearing in White Salmon, Wash., on the suit involving compensation to Northwestern Electric Co. for damage to its property at the mouth of Big White Salmon River as a result of the water impoundment behind Bonneville Dam. This is the suit mentioned earlier in which a number of Indians sought to participate. Davis reported to Johnson that the company's attorney tried to prove that the Indians had suffered losses to their fishing rights as a result of Bonneville Dam. Government attorneys tried to show that building Bonneville did not alter a situation in which the Indians' fishing rights already had been destroyed by Northwestern's dam on the Big White Salmon River and by a state fish hatchery near the mouth of the river. ${ }^{44}$ Thus, it would appear that the government was concluding an agreement with the Indians to compensate for loss of fishing sites resulting from Bonneville's construction on one hand while seeking to prove there was no damage on another hand.

So far as available files are concerned, the issue of fishing sites was then quiet until nearly the end of the year. Then, another agency jumped in. On December 19, Fred J. Foster, the regional director of the Bureau of Fisheries, wrote Meldrum, the Army land official, inquiring about the negotiations to purchase Jessup's property. He tossed in another potential obstacle: "If these negotiations and proposed agreements with the Indians are in any way related to their taking of fish, it is my opinion that such 
agreements should be submitted to the Acting Commissioner of Fisheries at Washington, D.C., for his consideration in connection with possible rights and activities of the Bureau of Fisheries before being consummated by the War Department and the Indians." ${ }^{, 45}$

The Corps acquiesced. In a reply December 22, Meldrum said his office planned to acquire the entire Jessup tract partly on behalf of the Bureau of Fisheries and partly for the Indians, "who have been accustomed to acquire their supply of salmon from the Little White Salmon Hatchery." At the same time, Meldrum said the Bonneville District of the Corps was sending a report to the Chief of Engineers asking authority "to acquire the several fishing camp sites for the Indians, which have been mutually agreed upon by this office and representatives of the different Indian Agencies." He said he would direct the Chief of Engineers' attention to Foster's request for consideration. ${ }^{46}$ There the matter rested at the end of the decade, slightly more than two years after the gates of Bonneville closed, drowning the ancient and accustomed fishing sites for a distance of 40 miles. 


\section{NOTES}

1. The tribal name on the 1855 treaty is spelled Yakama. Later, the spelling became Yakima and that spelling was used through most of the period of this report. The Yakama Indian Nation returned to the old spelling in 1993. This paper conforms to the spelling used in correspondence cited in each period.

2. Joel Palmer, report to George W. Manypenny, Office of Superintendent of Indian Affairs, July 9, 1855.

3. Palmer, "Proceedings at Indian Treaties in Wasco near the Dalles of the Columbia, June 22, 1855." Attachment to Palmer Report to Manypenny, July 9, 1855.

4. Treaty with the Wallawalla, Cayuse Etc. 1855.

5. George W. Gordon, Report to the Commissioner of Indian Affairs, Jan. 19, 1889, paragraphs $29,31,64,66,74,91,92,96,102$ (pages of the report are unnumbered).

6. Tommy Thompson, affidavit included in Edward G. Swindell Jr., Report on Source, Nature and Extent of the Fishing, Hunting and Miscellaneous Related Rights of Certain Indian Tribes in Washington and Oregon, 1942, 150, 151.

7. Swindell report, Thompson affidavit, 144, 155.

8. Swindell report affidavits, 158, 161, 169, 173.

9. William Willingham, Army Engineers and the Development of Oregon, (Portland: Army Corps of Engineers, 1983,) 8, 9, 95.

10. The Oregonian, Portland, Oct. 5, 1933, 1.

11. Oregon Journal, Portland, Jan. 6, 1934, 1.

12. William Willingham, Power in the Wilderness, (Portland: Army Corps of Engineers, 1987,) 47.

13. Frederic L. Kirgis, memo to the Commissioner of Indian Affairs, June 15, 1937, Box 115, Yakima Indian Agency, 1925-1967, 036.1-052, Bureau of Indian Affairs, Record Group 75, National Archives - Pacific Northwest Region, Seattle.

14. Nancy Graybeal, deputy regional forester, memo to forest supervisors in U.S. Forest Service Region 6, July 6, 1992, Forest Service files, Region 6, Portland, Ore. 
15. Kirgis memo to Commissioner.

16. William Zimmerman, Jr., letter to Kenneth R.L. Simmons, June 26, 1937, Box 115,Yakima Agency, BIA, RG 75, NA-Seattle. There was no explanation for his inclusion of the Coeur d'Alene Tribe whose reservation is in northern Idaho about 50 miles southeast of Spokane and far from the section of the Columbia River affected by Bonneville Dam. It is possible, however, that they did have rights on the segment that would be affected by Grand Coulee Dam, which also was then under construction.

17. Ibid.

18. Ibid.

19. O.L. Babcock, unaddressed memo, June 28, 1937, Ibid.

20. F.R. Anderson, letter to M.A. Johnson, Sept. 13, 1937, Ibid.

21. Kenneth R.L. Simmons, letter to Commissioner of Indian Affairs, Nov. 23, 1937, Ibid.

22. John Herrick, letter to Col. John C.H. Lee, Nov. 21, 1938, Ibid.

23. Simmons, letter to John Herrick, assistant to the Commissioner of Indian Affairs, Dec. 9, 1938, Ibid.

24. Oscar L. Chapman, letter to Kenneth R.L. Simmons, Jan. 26, 1939, Ibid.

25. M.A. Johnson, letter to Don E. Meldrum, Jan. 28, 1939, Ibid.

26. Theron D. Weaver, report to the Division Engineer, Mar. 7, 1939, files, Army Corps of Engineers, Portland District.

27. Ibid.

28. Minutes , meeting of tribal delegates at The Dalles, Feb. 28, 1939, Box 115, Yakima Agency, BIA, RG 75, NA-Seatle.

29. Report from Warm Springs Fishing Committee attached to minutes of Feb. 28 meeting, Ibid.

30. Weaver report of Mar. 7, 1939. 
31. Johnson, letter to Don E. Meldrum, and letter to J.W. Elliott, both dated Apr. 13, 1939, Box 11, Field Agent, The Dalles, Ore., 1939-53, 155 K-S, Bureau of Indian Affairs, Record Group 75, National Archives - Pacific Northwest Region, Seattle.

32. Frank Winishut, Jerry Brunoe and Isaac McKinley, letter to Don E. Meldrum, May 24, 1939, Ibid.

33. Philip Olney, David Miller, Thomas Yallup and Alex Saluskin, letter to "Army Engineering Corps," May 24, 1939, Ibid.

34. Minutes, Celilo Fish Committee, June 7, 1939, Box 12, Field Agent, The Dalles, 1939-53, 155 U, Bureau of Indian Affairs, Record Group 75, National Archives Pacific Northwest Region, Seattle.

35. Sally Ann Joyce, Tommy Thompson, Willie Yallup, Martin Spedis, Joe T. Estabrook, letters to M.A. Johnson June 9, 1939, Box 11, Field Agent, 155 K-S, BIA, RG 75, NA-Seattle.

36. C.G. Davis, letter to M.A. Johnson, June 10, 1939, Ibid.

37. The Umatilla report of June 5 did not turn up in the National Archives files.

38. Weaver, letter to M.A. Johnson July 12, 1939. Army Corps of Engineers, Portland District files, and Box 11, Field Agent, BIA, RG 75, NA-Seattle.

39. Johnson, letter to Commissioner of Indian Affairs, Aug. 17, 1939, Box 11, Field Agent, BIA, RG 75, NA-Seattle.

40. Resolution, Yakima Tribe, Aug. 9, 1939, Ibid.

41. Meldrum, letter to M.A. Johnson, Aug. 30, 1939, Ibid.

42. Davis, letters to M.A. Johnson, June 28 and Aug. 4, 1939, Ibid.

43. Davis, letter to J.M. Jessup, Sept. 21, 1939, Ibib.

44. Davis, memo to M.A. Johnson, Aug. 11, 1939, Ibid.

45. Fred J. Foster, letter to Don C. Meldrum, Dec. 19, 1939, Ibid.

46. Meldrum, letter to Fred J. Foster, Dec. 22, 1939, Ibid. 


\section{CHAPTER III: THE FORTIES - WAR AND RENEGOTIATION}

\section{Delays}

Once the Army Corps of Engineers had agreed to acquire and improve fishing sites for the tribes along the Columbia River, the issue virtually disappeared from the files of both the Indian Service and the Corps. M.A. Johnson, the Yakima Agency superintendent, referred to fishing sites in a letter January 8, 1940, to "field aid" C.G. Davis in The Dalles, but his comment appeared to be about existing sites, not the promised new ones. At a meeting of fishermen on January 3, Johnson said, "I discussed with them quite frankly the land and law and order situation as it now exists at the fishing sites on the Columbia River and advised them that a serious effort was being made by the Department to improve these conditions in every way possible."

Chief Tommy Thompson of the Wyam river people brought the issue to Washington's attention with a telegram to the Office of Indian Affairs on January 15. A baffled J.R. Venning, chief of the agency's "miscellaneous section," wrote Yakima Superintendent Johnson, asking for an explanation. "Am not favorable to resolution adopted by Yakima Council forwarded to you by Supt. Johnson regarding final settlement of disputes during fishing season here," the telegram stated. "Please delay action for time being. May be able to appear your office in Washington, D.C." Said Venning, "We are unable to locate any such resolution here awaiting action of the Office." In case there was such a resolution, Venning asked Johnson to find out the chief's objections. $^{2}$ 
Johnson responded with a letter to the Commissioner of Indian Affairs in which he said he assumed Chief Thompson was referring to the Yakima, Warm Springs and Umatilla tribal resolutions accepting the six in lieu sites. "These resolutions were transmitted to your office on August 17, 1939," he said. As for the chief's objections, Johnson was as baffled as Venning. "Mr. Thompson was present at practically all of the joint meetings of the Indian fishermen from the various reservations when these negotiations were in progress and I do not recall that he voiced any protest at that time," Johnson wrote. He said he would ask Davis at The Dalles to look into it and, in a postscript on Davis's copy of the letter, to contact Tommy Thompson "and see whether or not he has any definite objections to the settlement ..." ${ }^{\prime 3}$ The files reveal no further correspondence on the issue.

In fact, not until April, does the issue of Indian fishing sites come up again. On April 29, Don E. Meldrum, head of the land section for the Corps of Engineers at Bonneville, responded to an inquiry from Davis, the Indian agent at The Dalles, about the rights of Indians to fish below Bonneville Dam. Meldrum assured Davis that no statements had been made by the Corps concerning fishing rights below the dam except for an exchange between O.L. Babcock (who was superintendent of the Umatilla Indian Agency) and Sally Joyce of the Cascade Tribe of Columbia River Indians on May 23, 1939, during a Corps-conducted tour of proposed replacement sites on the river. Babcock assured Joyce that fishing rights below the dam were not affected by the Bonneville construction and that the Cascade Indians would be able to 
use the Herman Creek and Wind River sites above the dam, Meldrum wrote. A handwritten note on the bottom of the BIA file copy of the letter states, "Read it to Sally Joyce. Also typed a copy and mail to Sally Joyce 5-7-40."^4

By the end of 1940, both Indians and Indian agents were asking about progress on the sites. On December 2, Davis relayed to Superintendent Johnson some requests from William Yallup of Rock Creek. On the same date, Johnson wrote to the Corps inquiring about the status of site acquisition. Yallup asked that the Indian Office temporarily arrange camping places during the fishing season at the Big and Little White Salmon River sites. These were two of the sites the Corps was to acquire for the Indians and Yallup complained that there was then room for only one or two families at each, where space was needed for 20 families at each. He also asked that officials at the fish hatchery (a state hatchery at Little White Salmon) give "fair and impartial" treatment to Indians in distributing the salmon after they were stripped of their eggs. “... it is claimed that as long as there are any white people around, the Indians are not allowed to have any of these fish," Davis said. As usual, Davis asked his superior to try to fulfill the Indians' requests. ${ }^{5}$

On December 5, Meldrum, the Army Engineers' land manager, responded to Johnson's inquiry about the sites with the first report of a money-caused delay. "The preliminary work incident to acquiring title to said lands has been completed, but it is not anticipated that funds will be available until an appropriation is made by the next Congress," Meldrum wrote. An exception was the site at the mouth of Big White 
Salmon River. Meldrum said that land would be acquired as a result of the government's condemnation suit against Northwestern Electric Co., which was finally set for a hearing on January $7,1941 .^{6}$

A few days later, James Jim, also expressed concern about money in regard to the sites. Jim, an Indian living in Hood River, wrote Superintendent Johnson inquiring about a report that Henry Charley of Hood River had petitioned for money instead of land for the damage to the fishing site at Underwood. "Some of us objected to above petition," he said. ${ }^{7}$ In his reply, Johnson reminded Jim of the "recently completed negotiations" (almost a year and a half before!) in which the tribes agreed to accept five tracts of lands in compensation for lost fishing sites. At this point, it can't be determined whether Johnson wrote "five" rather than six - the number actually agreed on - through a simple mistake of memory or because somewhere in the bureaucracy a change had been made. In any case, he reminded Jim that the tribal leaders had specifically stated they wanted sites, not money, for their losses. The letter did not mention Henry Charley. ${ }^{8}$

By 1941, the Indians were asking when they would get their sites. Purchase of the sites "is now awaiting appropriations of funds by Congress for acquiring the land agreed upon," Yakima Indian Agency Superintendent Johnson wrote on March 14, 1941, to Isabelle May Underwood Bullard of Castle Rock, a Yakima Indian who had inquired about damage claims. "The War Department has recently advised me that they hoped to get this matter started in the near future." On May 24, Johnson wrote 
Meldrum of the Corps of Engineers on behalf of "a number of the Indian fishermen" to inquire about progress toward buying sites. ${ }^{10}$ Meldrum replied that the Corps expected little difficulty in acquiring the site at the mouth of Big White Salmon River but the other sites probably could not be obtained before the fall of 1941 . The Secretary of War had recently approved a settlement with Northwestern Power Co. of the condemnation suit, leaving only the claims of 40 Indians, which Meldrum said were "only minor interests." Funds were not available to buy the other six sites (again, there seems to be confusion of numbers - the final agreement was for six sites including Big White Salmon). However, Meldrum said recent news items from Washington, D.C., had mentioned a sum of $\$ 50,000$ and "it is expected that ample funds will be available soon after June 30th [then the end of the federal fiscal year] for the completion of our land program." He cautioned that all the sites could be acquired only by condemnation, a process that would take too long to be completed that fall. ${ }^{11}$

\section{Legalities}

The new fiscal year did not bring immediate action. On July 21, Davis forwarded to Johnson a letter from Mary Jessup of Cook, Wash., who had taken over her husband's activity of bothering Davis about the Little White Salmon site, land which the family wanted to sell to the government. The couple "cannot act as a public servant in caring for the Indians who have been flooded off their accustomed fishing places," she wrote, adding, "the Department of Indian Affairs will have to arrange to pay for premises occupied by the unfortunate Indians." Davis added his own 
interpretation of Mrs. Jessup's remarks: "I believe this lady means that they are getting tired of waiting on the War Department."12 The next month, Davis was writing to Johnson about Ellen Andrews Thompson, wife of chief Tommy Thompson, who had inquired about the Northwestern suit because she and her husband once had a house on Wind River that was flooded by the Bonneville backwater. "She says that she would prefer to have a place to stay so that she could obtain fish in that territory, rather than the cash benefits," Davis wrote. "But she believes that the camps the War Department have [sic] promised for the Indians are to recompense them all for the loss of actual fishing places and that this law suit is to recover damages so that they can rebuild their places." $" 13$

A few days after Davis' inquiry on behalf of Mrs. Thompson, both the lawsuit and work toward acquiring and improving the area involved in the suit - the Big White Salmon site - came to an impasse. After more than a week of hearing evidence, U.S. District Court Judge Lloyd L. Black in Tacoma dismissed the jury and said he probably would declare a mistrial on grounds the Indians had failed to show evidence of actual damage they had incurred. In addition, he said he thought the Indians should not make any settlement then because it would be for only a small part of potential damages to the entire run of salmon. Judge Black's comments were reported to the Commissioner of Indian Affairs by Johnson, the Yakima Agency Superintendent, who said he also had inquired from Corps of Engixeers officials attending the trial about the fishing sites. The War Department officials "seem to feel that all progress on this 
project would now be at a standstill and they expressed an unwillingness to go ahead and make the improvements on the 4.19 acres they are securing" at Big White salmon, Johnson wrote. The superintendent said he believed the Indians would be willing to drop the suit if the Army would go ahead with the improvements. "The fact that the War Department has been unable to fulfill any of the agreement that they made with the Indians, in my opinion, is one of the prime reasons why it was not possible to settle this action out of court," he wrote. ${ }^{14}$ It was months before he got a reply.

In a startling example of business as usual, on Dec. 8, 1941 - the day after the Japanese attack on Pearl Harbor brought the United States into World War II - the Portland District Engineer for the Army Engineers wrote to his superior, the North Pacific Division engineer, recommending several actions to end the Northwestern Electric condemnation suit in view of "the apparent futility of again attempting to dispose of the case in court.” The District Engineer, Lt. Col. C.R. Moore, proposed going ahead with the payments of $\$ 10,000$ to Northwestern for a flowage easement over 44.15 acres of land, a perpetual easement over 4.15 acres and acquisition of title to 4.19 acres for "a salmon fishing camp site needed for the exclusive use of the Indians." He also recommended payment of $\$ 521.58$ to Pacific Power \& Light Co. for the cost of relocating a power line in the vicinity. Both companies had agreed to the amounts and the suit remained unsettled only because of the individual Indian fishing claims.

Col. Moore for the first time in the available correspondence files outlines just 
what the Indians wanted - damages in sums ranging from $\$ 10,000$ to $\$ 1$ million. "This testimony involved the question of whether or not the operation of the Bonneville Dam will eventually destroy the salmon run in the Columbia and White Salmon Rivers," Moore wrote. He called the admission of that evidence "a radical departure from the usual measure of damages in a condemnation action instituted for the purpose of acquiring land." Moore also said the site the Corps of Engineers was acquiring was adjacent to the flooded site it would replace. He quoted Indian Agent Johnson as saying the new site "placed the Indians in practically as good a position as they were prior to construction of the Bonneville Dam." However, "under prevailing conditions induced by the dam," the Indians would now have to go 3,600 feet upstream by boat to obtain their fish. "This exception ... was the one item emphasized by Judge Black in discussing the case informally in chambers," Moore said. Moore had a plan for disposing of the claims by the more than 100 Indians too. (The number of Indians involved in the case is reported differently in every document.) Because they are wards of the government their claims should be determined by "representatives of the Wildlife and Game Department, the Bureau of Indian Affairs and the War Department, without resort to court action." He recommended taking care of the Indian claims by guaranteeing them delivery of discarded salmon carcasses from the government hatcheries "so long as the government shall continue to take salmon from said streams for propagation purposes." That recommendation, "if faithfully performed, will eliminate the possibility of the Indians again appearing in court in connection with 
flowage questions arising as a result of the construction of Bonneville Dam," he wrote. ${ }^{15}$ A copy of Moore's recommendations also went to the United States Attorney asking if he approved them. ${ }^{16}$

Meanwhile, Edward G. Swindell, Jr., an associate attorney in the United States Attorney's office in Seattle, was assigned to investigate Indian treaty fishing rights and practices along the Columbia and he apparently visited the river and the Yakima Reservation in late September. ${ }^{17}$ His comprehensive report was not issued until July 1942.

\section{To The Top}

Despite the war, Superintendent Johnson's September inquiry about the status of the site acquisitions appears to have worked its way, slowly, to the top of the bureaucracy with the Secretary of the Interior eventually passing on the question to the Secretary of War. On January 1, 1942, Robert P. Patterson, Under Secretary of War, assured the Interior Secretary, who was then Harold L. Ickes, that if Congress failed to pass the Rivers and Harbors Bill containing the authorization for site acquisition, his department would "initiate and support legislation pertaining to the Indians' claims."

But word did not reach Johnson until February. A reply had been written, explained W. Barton Greenwood, the Acting Commissioner of Indian Affairs, but "was inadvertently misplaced and not sent." The news then wasn't good. The Office of Indian Affairs had been informed that the War Department did not have the authority to use its appropriations to buy the "fishing sites in lieu of those sites which were 
flooded in the Bonneville pool." This may be the first time the term "in lieu" was used to refer to the sites. Patterson had not mentioned a lack of authority. However, Greenwood said the Rivers and Harbors Bill then still before Congress included an authorization for the Corps of Engineers to use funds already appropriated for the purchase. "Action on this bill is expected in the near future," he wrote, and if enacted would allow the Army to carry out its agreement. Greenwood added, "It is apparent that the War Department is making a sincere effort to carry out its agreements ..." He hoped the Indians would be patient and not file another law suit. "It is our opinion that within a reasonable time new sites will be available to the Indians," Greenwood concluded. ${ }^{19} \mathrm{He}$ did not define "reasonable." A handwritten note on the bottom of the BIA file copy says, "Explained to Tommy Thompson March 7, 1942. Copy given to J. Whiz for the chief $3 / 11 / 42 . "$

Apparently the Indians used at least the Big White Salmon site despite its uncertain status. The next reference to sites, a July 6 memo to the Commissioner of Indian Affairs from the Acting Director of the Fish and Wildlife Service, refers to "an Indian fishing problem at Big White Salmon River, Washington and a possible solution of the same." The memo outlined a meeting that had occurred July 3 attended by Samuel J. Flickinger of the Office of Indian Affairs, Howard Polinger of the Real Estate Branch of the Corps of Engineers and Milton C. James and Clifford Presnall of the Fish and Wildlife Service. They agreed that during the season when eggs were being taken from the salmon at fish traps on the Big White Salmon River the Fish and 
Wildlife Service would transport the stripped salmon carcasses to the Indians camped at the mouth of the river daily. "... every reasonable effort will be made to see that the carcasses will reach the Indians in good condition," wrote Charles E. Jackson, the Acting Fish and Wildlife Service Director. Similar efforts would be made at the Spring Creek traps and the Indians could have the dead salmon from the Little White Salmon traps "whenever they come in via the road." In exchange "it is expected that the Indians will refrain from spearing below the traps at all times during the salmon run." If there were more salmon than the hatchery could use or if the run dwindled to a point where the hatchery was no longer trapping, Jackson said the Indians "may be granted special spearing privileges." He said the state would enforce conservation measures but not require the Indians to obtain state licenses. He asked that the superintendent of the Yakima reservation keep the fish service informed about the number of Indians at the camp site.

Jackson also provided the first reference to war-caused delays in acquiring and improving the sites. At one point he said, "It is understood that the U.S. Engineers intend to give the Indians definite assurance of camp ground use at the mouth of Big White Salmon River and that they will seek funds for improvement of this and other camp grounds after the paramount needs of war have been fully met." Concluding, Jackson's memo stated:

It is hoped that the Indians can be persuaded to do their part in conserving this important resource without resorting to costly litigation, at least for the duration of the war. The slight inconvenience that may be caused by the temporary inability of the U.S. Engineers to improve the Indian camp grounds is 
just another of the things that all citizens must cheerfully face during wartime. Your cooperation and that of the Indians concerned will be appreciated. ${ }^{20}$

The Indians were not satisfied, however. The site issue came up at a meeting of the Celilo Fish Committee on September $25^{21}$ and in the Yakima Tribal Council in mid-October. At the latter meeting David Miller, who had presided over the Celilo meeting the previous month, "expressed little faith in an agreement with the War Department that they would eventually acquire an adequate camping site and build it up for the Indians. He pointed out that an agreement was made by the War Department in 1939 and nothing further had been accomplished." There followed several complaints about the inadequacy of the proposed Big White Salmon site. The ground was steep, there was no place to camp and no place for a drying shed. The area they formerly used was completely flooded. The council finally appointed a committee representing the council and the fishermen to decide exactly what the tribe should ask for at the site..$^{22}$

\section{Health, Rights and Food}

The committee produced a resolution that noted, "conditions that have developed since the Bonneville Dam flood waters were raised have proven this to be an unsatisfactory camp site from a health standpoint and a fish drying standpoint due to stagnant water and lack of suitable drying area." The site could be improved by filling part of the flooded area or by acquiring "an alternate or additional site of two acres on the east side of Big White Salmon River" a mile above the current site. ${ }^{23}$ Yakima Superintendent Johnson reported the Indians' intended resolution to the Corps 
of Engineers on October 26. The October 23 meeting was the third in two months in an effort to settle the issue and avoid more litigation, Johnson said. He then described in detail the reasons for the Indians' dissatisfaction:

There are two unsatisfactory conditions affecting the 4.19-acre site selection made by the Indians and your department at Underwood as a camp site which was considered by the Indian fishermen before the flooding of this area actually occurred. First, the flooding left less area available that was level enough for drying shacks and so forth than the Indians had anticipated. As a result, their drying activities are very crowded and they all claim that it is difficult to dry their fish successfully. Second the flood waters that back up to the shore line of their camp grounds have practically no current and have a tendency to become very stagnant, being covered by a thick growth of green moss over most of the area.

Since there is no other place for the Indians to dispose of the offal from the fish than in this water, it soon becomes a serious health menace. When we were there last Friday it was almost impossible to stay at this camp site because of the objectionable odor of the rotting and decaying fish offal in the water..${ }^{24}$

Meanwhile, 1942 saw reports of two studies, one ordered at the highest government levels and the other informal and locally generated. Neither had immediate effects, but both would be cited in later wrangling over fishing sites. Attorney Swindell's investigations culminated in the Report on Source, Nature and Extent of the Fishing, Hunting and Miscellaneous Related Rights of Certain Indian Tribes in Washington and Oregon issued in July 1942. Swindell concluded that the Indians' off-reservation fishing rights were extremely limited in light of the recent Supreme Court decision in the case of a Klickitat Indian named Sampson Tulee, which, he said, "unequivocally disposed of any further question as to the right of the states to control and regulate non-reservation hunting and fishing activities of Indians 
so long as (1) the restrictions imposed are of a purely regulatory nature looking to the conservation of fish and wildlife resources and (2) such restrictions are applicable to Indians equally with others." That judicial interpretation inhibited the federal government from seeking to enlarge the Indians' rights, he added, but suggested that the states could do so, at least for subsistence hunting and fishing. That was what he had in mind in including in his report the descriptions of "the Indians' prediscovery manner of life they then enjoyed and continued to enjoy until conservation measures became necessary." He suggested that portions of his report could be used to justify "further statutory recognition of the rights" the treaties were intended to reserve. ${ }^{25}$ While Swindell was pursuing his study, Indian agent Davis at The Dalles was making one of his own, documenting the importance of salmon to the Indians. In a sample of five families, he calculated an average annual salmon consumption of more than 5,000 pounds. The consumption included fresh, dried and salted fish and "liquid sauce." His report was based on live weight estimating 20 pounds per fish and included no fish sold or traded. He noted, however, "during the summer time the normal family at Celilo feeds quite a number of additional Indians who stay with them and fish at the falls." Accompanying this report was a list of Indian homes in the Columbia River area from Stevenson to Alderdale on the Washington side and Hood River and Arlington on the Oregon side complete with names and a list of Indians who lived at Celilo most of the year. ${ }^{26}$ Some of those same names are still found in families along the river. Johnson responded with some calculations based on Davis' figures: a 
total of 63 families, meaning that 315,000 pounds of fresh salmon was used for their food. He cited a similar survey on the Yakima Reservation of 25 families indicating the average consumption was 1,800 pounds per family per year, so that the 500 reservation families consumed 900,000 pounds of salmon a year for a total of $1,220,000$ pounds for the two groups of Indians. That compared to a commercial catch on the river that varied from $1,879,880$ in 1939 to $4,830,625$ in $1941 .^{27}$

\section{Hope and Disappointment}

The matter drifted through 1943 and 1944. In March 1943, the Indians feared the Army would tear down their shacks at the Big White Salmon site. On March 12, Davis wrote to Yakima Superintendent Johnson asking him to see that the Indian property was protected. Davis said he had seen Henry Charley, a Hood River Indian, who said the War Department had purchased or condemned the Big White Salmon property and ordered the people living there (non-Indians) to move. According to Charley, the residents were told to move their houses or the Army would destroy them. "Henry said some man told him the Indians could have the houses for $\$ 400$," Davis said. "Henry is afraid that in burning the houses the Department may burn the Indian shacks, one of which he says belongs to him, one to Mary Ann Slim Jim Butler and one to Robert Kuneki. ${ }^{, 28}$ Johnson passed the letter on to Meldrum of the Corps' land section. ${ }^{29}$

Meldrum replied that the Northwestern Electric Co. land, subject of the long uncompleted condemnation suit, "is being acquired by the Government by direct purchase" and the only remaining step to close the legal case was to secure waivers 
from people living on the land. Some of those leasing the property own buildings on it and have been notified to remove them, Meldrum said. There was no mention of burning or protecting Indian property. ${ }^{30}$ But the role of the individual Indians who had involved themselves in the lawsuit once more delayed a final resolution. Assistant Attorney General Norman M. Littell told Oliver Malm, a special attorney for the Department of Justice in Tacoma, Wash., on July 24 that he should take no further action toward dismissing the condemnation case. The Department of Justice was waiting for notification from the War Department that the negotiations for direct purchase of the land had been completed. Also, no action should be taken until the Department of Justice was notified that substitute Indian fishing sites had been selected and approved. After that, Littell said, the Yakima Nation should be brought into the case "in order to defeat the claims of individual Indians, except for the loss of their fishing shacks." Compensation for those shacks was the only issue remaining, he said. $^{31}$

Finally, on August 23, 1943, Robert A. Lovett, the Acting Secretary of War, wrote to the Secretary of the Interior (still Harold Ickes) to inform him that a draft of a bill was being prepared to submit to Congress to authorize the Army to "acquire lands and provide facilities" to replace the submerged Indian fishing site. ${ }^{32}$ The Office of Indian Affairs sent a copy of Lovett's letter to Thomas Yallup, a leader among the Indian fishermen, through the Yakima Agency. In his accompanying letter, Walter V. Woehlke, assistant to the Commissioner of Indian Affairs, cautioned, "As you know it 
takes some time to enact legislation but we hope that this matter may be facilitated so that the Indians may resume fishing." ${ }^{33}$

But apparently nothing was done that year. May 4, 1944, J.W. Elliott, superintendent of the Warm Springs Indian Agency, wrote to T. Leland Brown, an attorney at The Dalles, enclosing Brown's copy of Senate Bill 1581, "which I understand has been pigeon-holed for the time being." Elliott then recounted a brief history of the fishing sites issues, listing the agreed-on sites as Eagle Creek and Tenino in Oregon and Underwood and Spearfish in Washington. "The matter has been pending since completion of these negotiations," Elliott wrote, "due we presume to a lack of funds with which to complete the program, although we understand that some of the sites have been acquired by the Department through condemnation actions." $\mathrm{He}$ added, "In my opinion it would be very desirable to carry this program to completion, inasmuch as the Indians have the understanding that this was to be done, and are getting somewhat impatient on account of the delay." The enclosed bill appeared "to be entirely in line with our understanding" except that it should cover acquisition of sites in both Washington and Oregon rather than only in Oregon, Elliott wrote. $\mathrm{He}$ asked Brown to do anything possible to have the measure brought up in Congress. ${ }^{34}$ Almost another year passed before there was action. On March 2, 1945, United Press reported:

President Roosevelt today signed a bill authorizing post-war construction of 291 river and harbor improvements at a cost of $\$ 381,968,332$. Included in the projects are: Restoration of Indian fishing grounds destroyed at Bonneville, Ore., by dam, $\$ 50,000 \ldots{ }^{35}$ 
The clipping was based on Public Law 14, Chapter 19, of the 79th Congress approved March 2, 1945. A section of that law authorized the Secretary of War to "acquire lands and provide facilities in the states of Oregon and Washington to replace Indian fishing grounds submerged or destroyed as a result of the construction of Bonneville Dam." The law said the Army could spend no more than $\$ 50,000$ from funds already appropriated or appropriated later for maintenance and improvement of existing river and harbor works. In other words, the Corps of Engineers would get no additional money but would have to take the money from its normal funding. The law provided that the sites be transferred to the Secretary of Interior for use by the Indians "subject to the same conditions, safeguards and protections as the treaty fishing grounds submerged or destroyed."

Passage of the bill sparked bitter recriminations within the Indian community. At an April 4, 1945, meeting of the Celilo Fish Committee. Andrew Barnhart told his fellow committee members damage to the fishing sites far exceeded $\$ 50,000$ and said "it was the fault of the younger group in accepting such a small amount ... that all Indians are not capable of setting a correct amount because many of them take in side money to sell out other Indians." He warned that the "proposed dam at Tenino (which became The Dalles Dam) would cause even greater damage." The minutes of the meeting record a people besieged: the state of Washington is trying to deny tribal fishing rights, arresting Indians for fishing on the Klickitat River; a new dam may destroy even more fishing sites than Bonneville Dam; younger members of the 
Yakima Tribe lack interest in preserving their rights. The committee laid plans to form a united front against the Corps of Engineers. Despite divisions, said committee member Jim Billy, "preservation of the fishing rights under the Treaty of 1855 is important to the welfare of the people of Indian descent." ${ }^{37}$

The next year, 1946, brought more trouble than progress although prospects at the beginning of the year appeared good. On January 11, William Zimmerman Jr., Assistant Commissioner of Indian Affairs, wrote to a "Mr. Simmons" (presumably Kenneth R.L. Simmons, the Indian Office attorney in Billings, Mont.) stating that "no special appropriation is necessary" for the Corps to begin buying sites. "The War Department has received a number of large appropriations any of which will be available for this expenditure." 38 The Army, however, said it wasn't that easy. Little more than a month later, the Secretary of War, Robert P. Patterson, informed the Secretary of the Interior (still Mr. Ickes) that the money left from appropriations before the 1945 law "is either obligated or programmed for other essential requirements and cannot be made available for the acquisition of the new sites." However, he said, "in view of the long outstanding agreement" the War Department would "make every effort" to squeeze the money out of its pending 1947 appropriation. ${ }^{39}$

Meanwhile, Indian agent Davis at The Dalles and his new supervisor at the Yakima Agency, L.W. Shotwell, were busy fending off a businessman who wanted to "get rid of the Indians" at their Celilo fishing grounds, where he wanted to build a motel. Davis wrote Shotwell on January 25, 1946, reporting that Nels Helmick, owner 
of a service station and general store at Celilo, had leased from Seufert Brothers Co. all the land between the general store and the railroad bridge west of the store except for a single block. "Mr. Helmick wanted to know if he was going to encounter opposition when it came time to get rid of the Indian camp there," Davis wrote. "I informed him of the Treaty of 1855 of right of the Indians to erect temporary drying or curing houses on lands bordering on the ancient fishing ground." Helmick asked for a definition of "lands bordering on fishing grounds" and, if the Celilo land is within that definition, could all the Indians use one large house instead of "having the place cluttered up with a lot of such shanties." His outrage barely concealed, Davis said, "He seemed to be of the opinion, as gained from talking with William Seufert, that he could just go ahead and use a bulldozer on the Indian shacks and clear them all out of that space and we couldn't do anything about it. I informed him that the minute that I discovered any such action I would get in telephone communication with you and possibly with the United States attorney." Davis said Helmick assured him he did not want trouble. Davis suggested that if Helmick got answers to his two questions "it would help to obviate trouble."${ }^{, 40}$

Shotwell responded on January 29 admitting he didn't have the definitive answers but expressing an opinion. "I doubt if the phrase 'lands bordering on the fishing ground' has been defined or its applications limited by the findings of any court," Shotwell wrote. But he said he believed the Celilo Indian structures came within the definition "and any disturbance of such occupancy could be made the basis 
of a serious damage suit." He added, "I believe the length of time which these buildings have occupied this tract would also weigh heavily in favor of the Indians." The new superintendent said he agreed that one large shed might be better than the current shacks but Helmick would need to have the Indians' agreement and make the single building available without cost to the fishermen. If he attempted to destroy the shacks without their agreement "I believe the Indians concerned could make him pay heavily for such action." A hand written note on the bottom of the letter says, "Taken up with N.O. Helmick on 2-1-46 at Celilo." ${ }^{, 41}$ There is no more correspondence regarding Mr. Helmick and his motel.

Near the end of the year, the aging Mr. Jessup with the Little White Salmon property, once more entered the scene. In a letter to Henry Charlie [sic], Jessup once more offered six acres of his land as one of the fishing sites, boasting that the area provided "adequate space for housing and other buildings ... as well as a large amount of clean cold water and firewood." He was willing to work out details later. Jessup concluded: "You can depend upon our co-operation at all times to the extent that we will join you in going on the warpath if necessary against the politicians who will deprive the Indians of all and everything they have if they have the opportunity." ${ }^{92}$

\section{Diversion and Division}

In 1947 the Corps of Engineers had both the authorization and the money to acquire the long-promised sites, but for unexplained reasons the Office of Indian Affairs proposed diverting some of the Bonneville pool money to Celilo, which had 
not been affected by that dam. The suggestion served to divide the Indians. The Indian Office created further delay by insisting that the tribes reaffirm their 1939 resolutions approving the six-site agreement and that the resolutions be in a form specified by the agency. Further frustrating the fishing families, a white logger usurped the one site acquired for them by building a log dump on it.

Distrust among the tribes was apparent in a March 10 letter from Henry Charley, then the chairman of the Celilo Fish Committee, to Yakima Agency Superintendent Shotwell. First came a plea for action. Referring to the 1939 agreement, Charley wrote, "Nothing has ever been done about this thing and all the Indians of Yakima Tribes and the Clickatats [sic] and the Mid Columbia Indians have talked in meetings and agreed that a camp site on the Big White Salmon is what they want. In your letter of last December you said you would inquire into this $\$ 50,000.00$ the Army Engineers have promised to spend for the Indian camp sites but there is still nothing done and we Indians are needing a place to camp for the fishing this spring."

The Cascade and "Clickatats" had heard that the Warm Springs Tribes had asked for the $\$ 50,000$ for buildings at Warm Springs. "The Indians of the Columbia Basin think this is not right because this money was to be spent for new fishing camp sites and we don't think the Warm Springs Indians have any right to say about this money," Charley wrote. He asked Shotwell to send him the Warm Springs minutes for a report to a meeting of Indians on March 16. And he wanted the matter straight before a March 27 session between War Department Engineers and the Indians. ${ }^{43}$ 
The District Director of the Indian Service, E. Morgan Pryse, interested himself in the March 27 meeting, writing to Shotwell and C.G. Davis, the agent at The Dalles, urging them to get the Indians there. Davis then called a meeting of Indians for March 21 to select representatives. Some Indians who didn't attend sent letters containing their recommendations for the sites. Those who did attend furnished Davis with a list of owners of "dry houses" at Wind River, Little White Salmon, Big White Salmon, Spearfish, Klickitat River and Tenino before Bonneville Dam. "Most of the Indians present seemed to think that the Federal Government should build them new dry houses; that each dry house destroyed must be replaced," according to an abstract in BIA files. The group selected as representatives to the March 27 meeting Robert Quaempts, Cecil Wesley, Roy Spino, Henry Charley, Carl Yahyowan, George Cloud and Albert Stahi. ${ }^{44}$

A few days later, on March 18, Davis wrote to Shotwell adding a few names to the list of dry house owners and suggesting that he contact Sally Ann Joyce, who he said "is a key figure in this case" and could supply additional names. ${ }^{45}$ On the same day, Davis issued a notice of the March 21 and March 27 meetings. It said, "A decision is sought whether to use the money promised by the War Department in providing camps at Herman Creek, Wind River, Big and Little White Salmon Rivers and Big Eddy on the Washington side, for fixing up the camp at Celilo, Oregon with new houses for the fishermen, including leveling the grounds, providing water and so forth." He asked those who could not attend to write him with their views. ${ }^{46}$ 
The Yakima Tribes then complicated matters further through a letter from Kenneth R.L. Simmons, who apparently had left the Indian Office and become the tribal attorney, to William Zimmerman Jr., the Acting Commissioner of Indian Affairs. Simmons said the Yakima wanted to be heard before any decisions were made on how to spend the $\$ 50,000$ available to the Corps of Engineers. "The only tribes of Indians who have any right to declare how this money should be expended are the Yakima and Umatilla Tribes of Indians who have recognized fishing rights in the Columbia River," he said. "I do trust that before any determination is made the Yakima and Umatilla Tribes will be consulted as to their desires in this matter." ${ }^{47}$

The meeting between the Indians and the Engineers, with half a dozen representatives of the Office of Indian Affairs and the Warm Springs attorney, was held on March 27 in The Dalles City Hall. Davis later provided what he labeled a "brief outline" of the session, a five-page single-spaced typed document. The Big White Salmon site was first on the agenda and Henry Charley, speaking for the fishermen there, said they wanted five things, headed by rebuilding the drying houses and living quarters for those who were there before Bonneville Dam. The other requests were for level ground, running water, an incinerator and drying racks. Henry Roe Cloud, who had become superintendent of the Umatilla Agency, and Jones Spencer of Yakima also emphasized the building of living quarters, which Davis said in his outline "was agreed to by Mr. Meldrum (of the Corps of Engineers) providing there is money available to do so." The statement takes on significance in light of 
disputes 20 years later. Several other of the Indians also said replacement of living quarters was a priority.

Mary Underwood Lane (Olson) commented that no Indian had ever fished at Herman Creek, one of the designated replacement sites, but half a dozen others named Umatilla and Warm Springs families who had fished there. There was some discussion of Spearfish vs. Three Mile Rapid as one of the sites and several people pointed out that Spearfish village would be under water and any improvements wasted if the proposed The Dalles Dam was built. "It appeared to be the policy of the War Department to refrain from placing improvements where they would be lost by inundation due to dam construction," Davis wrote. A similar problem would affect the proposed Tenino site and Joe Estabrook suggested building at Lone Pine Island on the Oregon side instead. Davis said Tenino, a site named in the 1939 agreement, "is apparently being eliminated, but establishing a camp at Lone Pine Island would apparently depend on river levels there. Floyd H. Phillips, the Indian Office's district forester in Portland, opened the afternoon session of the meeting by suggesting that $\$ 15,000$ of the $\$ 50,000$ Bonneville Pool money be diverted to Celilo. He said the government had an option to buy 34 acres there from Seufert Brothers for $\$ 2,100$ but did not have the money to complete the purchase. A number of houses were at Celilo ready to be put up but there was no money for the work. Meldrum of the Corps of Engineers asked Robert Quaempts, who was speaking for the Big White Salmon residents, if he were willing to divert the money if there was not enough to make the 
requested improvements at White Salmon. Quaempts said, No. Superintendent J. W. Elliott of the Warm Springs Agency said he thought the diversion of funds to Celilo would be a good thing but he did not favor the move unless the Indians who suffered losses in the Bonneville Pool approved. Phillips called for a standing vote and Alex Saluskin, a Yakima who fished at Celilo, reminded the gathering that no amount of money was specified when the government agreed to acquire replacement sites and improve them. It was agreed that the War Department would procure whatever funds were required to do the job, Saluskin said. Meldrum confirmed Saluskin's statement. He said the Corps of Engineers had estimated that $\$ 50,000$ would be enough but rising prices made it inadequate and the War Department had an obligation to make the improvements even if more money was needed. Mary Underwood Lane said most of the displaced Bonneville Pool fishermen now went to Celilo and improvements there would benefit them. The two standing votes gave a somewhat muddled verdict with some delegates voting both to divert the funds and against diverting them. Davis said, however, it was evident those against the diversion were in the majority. Phillips then said the tribal councils would have to reconfirm their approval of the original plan. If any money was left over after the expenditures in the Bonneville Pool, another meeting would be held to decide what to do with the rest. ${ }^{48}$

Pryse followed the March 27 meeting with a letter to the superintendents of the three Indian agencies telling them the tribal councils should act as quickly as possible on resolutions "confirming the decisions reached at The Dalles meeting." Interestingly, 
Pryse stated that Meldrum, the Corps of Engineers representative, had "informed the Indians that before positive action could be taken toward acquisition of the camp site" they would have to pass new tribal resolutions. ${ }^{49}$ Davis' report attributed the demand for new resolutions to Phillips of the Indian Office. Davis was there; Pryse was not. ${ }^{50}$

Davis wrote two letters to Shotwell reporting on the March 27 meeting, one he mailed and one he retained in files with a handwritten note stating "I didn't send it." The March 31 letter, which he did not send, comments on the Simmons letter to Henry Charley stating that the Warm Springs should have no voice in the fishing sites. Davis said he had not spoken to any other Indian Office officials about Simmons' comments but "it does pain me considerably." He noted that the fishing restrictions imposed in the 1865 Warm Springs treaty "have not been observed for many years, and the Commissioner of Indian Affairs has not insisted on such observance." He said he could not understand why Simmons brought up the issue. "If the Warm Springs Indians do not have a legal right to use the Columbia River for fishing purposes, they certainly do have a moral right which could probably be legalized," he wrote, adding, "I think we should all strive to unite the Indians from the three agencies in order that they may be better able to combat their common problems."

The next day, Davis wrote another letter in which he mentioned without comment the Simmons letter, merely enclosing a copy of it. He said he had reported on the March 27 meeting in a brief outline and was attaching to this letter a list of those attending and those who had lost houses to the Bonneville Pool. ${ }^{52}$ He attached a list of 
66 Indians who attended the meeting included their tribe and fishery. The other list named 22 Indians who had houses at Big White Salmon before Bonneville Dam, 15 who had houses at Little White Salmon, five with houses at Wind River and 13 at Cooks, the mouth of the Little White Salmon River.

Indians from Wind River and Little White Salmon met on April 2 and agreed on a statement to send to the (Yakima) tribal council. Johnny White set the priorities for replacement as:

I. Securing a land

II. Rebuilding of drying houses and living quarters

III. To maintain roads.

IV. To level ground

V. Provide running water

VI. Provide incinerator

VII. Provide drying rocks.

Dora Tulee suggested that the site be "a place further up above the Hatchery on either side of the river." Both statements appear to be part of the petition, which was signed by Dora Tulee, Mary Hunt, Sampson Tulee, Mary S. Cloud, Martha Sthia, Sue Tahkeel, George Cloud, James G. Tanewasha and Nawiat Tahkeel. ${ }^{53}$

The Indian Office certainly understood the Indians' wishes regarding use of the $\$ 50,000$. Edward G. Swindell, Jr., who had become the agency's district counsel in Portland, wrote to Simmons, whose law offices were in Billings, Mont., about other legal matters involving the Yakima. Near the end of the letter he commented on the money and the March 27 meeting, which Swindell attended. He said he assumed Simmons' information concerning the money was the same as that given at the 
meeting, "namely that the powers that be in the War Department in Washington were of the opinion that money or a portion could be diverted to Celilo." He added, "However, the Indians at the meeting turned thumbs down on the proposition and its [sic] probably just as well for the reason that the $\$ 50,000$ is far from adequate to do all that was agreed on several years ago. If the amount of $\$ 15,000$, as was considered at the meeting, was diverted, the War Department could use the diversion as a basis for claiming the Indians had agreed to accept a great deal less than was originally agreed upon. As it was, Mr. Meldrum again assured the Indians that his Department recognizes its obligation to carry out the original agreement." ${ }^{\text {54 }}$

The Warm Springs Tribal Council acted quickly to reaffirm the 1939 agreement. On April 11, Elliott, the Warm Springs Agency Superintendent, sent the District Director, Pryse, a copy of the resolution adopted on April $8 .{ }^{55}$ No copy of the resolution appeared in the files. On April 24, the Yakima Tribal Council followed suit, confirming the original agreement "with the additional recommendation that a study be made of the possible development of a campsite at Lone Pine Island on the Oregon side of the river and that some consideration be given to improvement of a camp site for the Indians living at Spearfish, particularly the development of water for this camp and the improvement of the road leading thereto known as the 'Colawash Trail." The resolution also stated that if money was left over after the Bonneville Pool acquisitions and improvements, the Yakima council would be willing to discuss uses of the money. The resolution also restated the original assertion that the replacement sites were 
compensation only for lost sites, not the fish. ${ }^{56}$ The resolution was passed along to Pryse May 2 by Superintendent Shotwell, who noted that the action was taken after several meetings with the fishermen..$^{57}$

Despite the Indians' definite rejection of diverting funds, the issue did not go away. On April 11, Sen. Guy Cordon, a Republican of Oregon, sent a telegram to T. Leland Brown of The Dalles law firm of Brown and Van Vactor informing him that the authorization to spend $\$ 50,000$ for Indian fishing sites "does not limit expenditure to the Bonneville Pool area but that legally it could be spent any where in the state of Oregon or Washington." Brown was listed as Warm Springs attorney in the list of those attending the March 27 meeting. ${ }^{58} \mathrm{~A}$ letter to Pryse the following day apparently came from Brown although the signature is missing. Brown enclosed a copy of the Cordon telegram and said:

I believe it is our duty to transmit this information to the Indians, for it is my opinion that part of the $\$ 50,000$ should be expended at Celilo, at least $\$ 15,000$ which is generally understood between all of us should be expended in the Celilo Fisheries.

The reason I am stressing this point is that it will be at least two years before we can receive an appropriation from Congress, and even then we may have a hard time getting this money. I believe the Indians upon being advised of the true situation and that you have obtained houses that can be erected for them at Celilo, that they will agree upon the expenditure of a part of the Bonneville funds for this use at Celilo. I know our Warm Springs Indians think along this line. ${ }^{59}$

Brown's assessment of the Warm Springs attitudes was not borne out in Davis's outline of the March meeting. The only person he recorded as speaking in favor of the funds diversion was Mary Underwood Lane, a Mid Columbia resident. ${ }^{60}$ 


\section{New Resolutions}

By early May the Corps of Engineers was demanding new resolutions from the tribes confirming the 1939 agreement. In a letter May 9 to Caples Dave of the Mid Columbia, Dick Darnielle, assistant real estate officer for the Corps at Portland, wrote: “... the War Department will not take further steps toward the acquisition of the various fishing sites discussed in the meeting above mentioned until such time as the various tribal councils have reaffirmed their previous understanding as regards the acquisition of such sites. Mr. Swindell of the Office of Indian Affairs recently advised that he expected the approval of the fishing sites by the various tribal counsels [sic] would be forthcoming." He said "it was understood" that after the sites had been acquired there would be another meeting to agree on a plan for spending any money remaining from the $\$ 50,000 .{ }^{61}$ By this time, of course, both the Warm Springs and Yakima councils already had reaffirmed the 1939 agreement.

The Warm Springs apparently began to waver on the Tenino site, not being willing to eliminate it but not objecting to development of the alternate Lone Pine site. District Director Pryse of the Indian Affairs Office wrote the Warm Springs Superintendent, Elliott, on May 23 asking him to get the tribal council to clarify its position. "It was our understanding that the Tenino site had been definitely eliminated from consideration after our meeting at The Dalles," he wrote. Pryse also pointed out that the Corps's "Mr. Meldrum insisted that he be assured of the unanimous agreement of the tribes involved before they attempted to acquire any of the proposed sites." In 
the absence of that unanimity, Pryse said he doubted that the Corps would take any action and he recommended that the "the tribes should strive to reach an agreement" before the Indian Affairs Office went to the Engineers for action. Pryse too said he understood another meeting would be held after the sites were acquired to determine use of any remaining money. ${ }^{62}$

The Indian Office apparently was in no hurry to push the matter. It was July 26 before Swindell advised Yakima Superintendent Shotwell that the Yakima council's April 24 resolution "will be acceptable to the war Department authorities if the sixth paragraph is revised ..." He then provided a wording for the substitution of the Lone Pine site for the Tenino site and the desired improvements at Spearfish. He also suggested adding to the next paragraph that the Bonneville Pool money could be used elsewhere if some remained after acquisition of sites and the completion of the improvements thereon, adding the italicized words. ${ }^{63}$ More than two months later, an "embarrassed" Indian Office was urging the tribes to act. District Director Pryse, in an October 6 letter to Superintendents Shotwell at Yakima and Henry Roe Cloud at Umatilla, said the War Department "again called this office last week" about the resolutions. "Up to the present time, we are not advised as to whether any of the councils has formally considered the proposed resolutions except Mr. Elliott's group (Warm Springs), and it was indicated they were still desirous of retaining the Tenino site, but that they would be willing to reconsider the matter of its elimination in the light of action which might be taken by the Yakima and Umatilla Councils." He added, 
"We are in a more or less embarrassing position with the War Department" and urged the superintendents to "urge early and favorable action."

Meanwhile, Mary Underwood Lane brought to Davis's attention an excavation for a log dump at Big White Salmon River, the only site the Corps had acquired for the Indians. In a handwritten note dated June 12, Mrs. Lane said "there has been much concern among some over there." ${ }^{65}$ Davis, who had been on vacation, returned July 1 and promised to investigate, adding, "if it would interfere with fishing activities of the Indians - getting their fish from the hatchery - or with their camping activities, I will do what I can to stop it. ${ }^{966}$ On July 7, Davis wrote Superintendent Shotwell at Yakima after visiting the site. “... it appeared to me that the road and slide constructed by the logging outfit is actually a trespass on this property acquired for the Indians," he wrote. Although the land had not yet been turned over to the Indian Office, he asked Shotwell to call the problem to the attention of Meldrum of the Corps of Engineers. ${ }^{67}$ Shotwell apparently sent the matter to his superiors and on July 30, Pryse, the District Indian Office Director wrote to the Corps' District Engineer concerning the application of Rogers Logging Company to build a "row of piles and dolphins in the Big White Salmon River." There was an August 1 deadline for protesting the application. Although "we are not aware as to what effect the proposed construction will have upon the rights of the Indians," Pryse asked the Corps to consider those rights in considering the company's application. ${ }^{68}$ On August 6, Davis wrote Mrs. Lane that Mr. Rockwell of the Corps of Engineers had promised to have the logging operation removed if it 
interfered with the Indians. "I am still hopeful this will be done," he said. ${ }^{69}$ On September 30, Davis wrote Warm Springs Superintendent Elliott asking him to obtain signatures on a Celilo Fish Committee paper protesting the logging operation. The paper was written after absence of Warm Springs delegates made a quorum impossible for a scheduled meeting that day. He explained that "the entire operation of dumping logs in the river on the west shore was and is a hindrance to camping of the Indians, the said logging operation being situated on the four acres planned for a camp site for Indians, and which we believe has been acquired by the War Department for that purpose. $" 70$

Nothing was resolved during 1948 . The tribes could not agree on substituting Lone Pine for Tenino as one of the sites and the Corps of Engineers declined to act on any sites until the tribes were unanimous on them all. Meanwhile, the Corps filed suit against Rogers Logging Co. for moving onto the only site acquired for the Indians Underwood at the mouth of the Big White Salmon River.

It appeared in January as if the Umatilla Tribes would join the Yakima and Warm Springs Tribes in approving new resolutions reconfirming the 1939 agreement with the substitution of Lone Pine for Tenino. On January 21, Roe Cloud, Superintendent of the Indian Agency at Umatilla, wrote to L.W. Shotwell, the Yakima Superintendent, that the Umatilla Tribal Council members would be at the Yakima Reservation January 28 to discuss the Lone Pine issue with the Yakima Tribal Council. About 10 to 12 men would make up the Umatilla delegation and Roe Cloud 
said he was allowing them to use two government cars for the trip. "My personal opinion about this Lone Pine matter is that this trip is wholly unnecessary as in five minutes the Business Committee here could pass on it ...," Roe Cloud wrote. He said he consented to the trip only "because the Army Engineers must have unanimity of decision by the three tribes ...,"71

By April 1 nothing had happened. At a meeting of the Celilo Fish Committee that day, Swindell, the Indian Office Attorney, said only a resolution from the Umatilla Tribe was needed before the Army Engineers began acquiring the sites. He said he understood a recent change in the organization of the Umatilla Tribes would allow the Tribal Council to take actions that formerly required approval of the General Council, that is, the entire membership of the tribe. Setting up the new governmental machinery had delayed action, but Swindell said he hoped it would be forthcoming soon. Swindell also informed the committee that Meldrum, the Corps land officer "who was a sincere friend of the Indians," had died and his place was being taken by Rockwell, who was "cooperating and carrying out Mr. Meldrum's wishes."72 Meldrum's death meant that three of the government officials who appeared from their correspondence to be most sympathetic to the Indians were now gone, replaced by men whose letters indicate less patience with Indians' concerns and methods of operation and more concern for the tight rules of bureaucracy. Yakima Superintendent M.A. Johnson had been replaced by L.W. Shotwell, Umatilla Superintendent O.L. Babcock, who first called attention to the Indians' claim for damages to their fishing sites, had been 
replaced by Henry Roe Cloud and Don Meldrum, the Corps land officer, had been replaced by Rockwell, whose later actions failed to fulfill his initial promise as a friend of the Indians.

The Umatilla council apparently had requested of someone that Swindell, the Indian Office Attorney, appear at the General Council's meeting to explain the substitution of the Lone Pine site for Tenino. Swindell said he did not attend because he saw little justification to appear "solely for the purpose of explaining this matter which has been the subject of so much correspondence." Expressing exasperation, Swindell said both he and District Director Pryse believed "that if the Umatilla people could not understand the situation after the thorough written explanation over the months, as well as the oral explanation which I gave the Umatilla members of the Celilo Fish Committee at our meeting with them in May, there was little likelihood that a personal appearance by me would accomplish anything." He suggested that a recently approved tribal attorney might be willing to review the correspondence and advise the tribe at its July meeting. Swindell pointed out that the Umatilla people originally had indicated that the Tenino site was not one of their usual and accustomed fishing places and therefore they felt they should not pass a resolution regarding it. But, the federal attorney said, the War Department wanted resolutions approving the change from the same three bodies that approved the original site selection. ${ }^{73}$

C.G. Davis, the Indian agent at The Dalles, wrote Roe Cloud July 20 inquiring on behalf of the Mid Columbia Indians about the status of the Umatilla resolution. The 
next day, the Umatilla superintendent responded, exasperation showing in every line of the letter:

They have had this matter up for consideration for almost two years [in reality, it was slightly more than one year] and for one reason or another they refuse to take part in the settling of this question. One speaker would get up and say, "if we give up Tenino for Lone Pine, we will lose our treaty rights." Another person says, "if we have anything to do with this question involving the expenditure of $\$ 50,000$, the Government will make us pay back the pro rata share of the $\$ 50,000$ to the United States Government." Another says, "this is an appropriation strictly for the Rock Creek Indians along the Columbia whose sites have been flooded by the Bonneville Dam and the money is strictly for their benefit. We should have no part in it because the money was not intended for the Umatilla Indians." ... Another says, "If we participate in this matter concerning the $\$ 50,000$, they will take just that much our of our Umatilla Reservation appropriations."

... no reasoning or extensive argument seems to change their feeling on this matter. From a legal standpoint, all tribes who fish at Celilo along the Columbia River will benefit by the expenditure of this money ... but unfortunately Indian reasoning does not coincide with the necessities required by legal technicalities ${ }^{74}$

Davis passed Roe Cloud's letter along to his supervisor, Yakima Superintendent

Shotwell, commenting that "it is apparent that there is little likelihood of any action by the Umatillas in this matter." He suggested therefore that the original plan be carried out. "My reason for making this suggestion is that the Indians who suffered losses as a result of construction of the Bonneville Dam stand to lose everything permanently until this is done," he wrote. He said he believed no further action by the Yakima and Warm Springs councils would be required, "but that merely a letter from you to the Army Engineers would be sufficient to cause action to be taken toward pursuing the original plans." ${ }^{.75}$ No reply to this idea appears in the files and the issue of Lone Pine 
continued to dominate the discussion.

On August 6, District Director Pryse of the Office of Indian Affairs wrote to Henry Charley of the Columbia River Indians assuring him the $\$ 50,000$ was still available "and will be used for the purchase and improvement of the sites ..."76

Through September the Corps, the Indians and Davis, the Indian agent at The Dalles, struggled to fix a legal definition of the Lone Pine site. Spring floods washed sand away from the favored site, leaving "only bleak rocks there." A site on Lone Pine Island nearby was proposed, but it would require a bridge ${ }^{77}$ Finally, on October 22 , the Celilo Fish Committee approved a precisely defined area on the shore near Lone Pine Island. The committee noted that the site contained many large rocks but said a small amount of dynamite would take care of that problem. ${ }^{78}$ The Warm Springs Tribal Council approved the site by resolution on November $5^{79}$

Meanwhile, back at Big White Salmon, the U.S. Attorney for Western Washington, acting at the request of the Department of the Army, filed suit in U.S. District Court in Tacoma against Rogers Logging Company of White Salmon accusing the firm of illegally building and using a log dump on government property - the site acquired for the Indians. The complaint said the company refused to move despite government requests and that it was obstructing a navigable stream - the White Salmon River - and interfering with the occupancy and fishing rights of the Indians. The government asked for an injunction forbidding the company to trespass on the land or to block the river channel and that it pay damages of 25 cents per board foot 
for all logs handled at the facility. ${ }^{80}$ The company did not back down. It sent its attorney, John J. Coughlin, and a Mr. Nelson to talk to Davis of the Indian Service at The Dalles. They convinced Davis that the company might have some legal right to be at the site and that "undoubtedly if the law suit progresses there would be some lengthy process of litigation that may keep the Indians from enjoying the use and occupancy of the proposed camp for some time." The two logging company men told Davis they would be willing to cooperate and Davis suggested it might be a good deal for the Indians and the government if the logging company stayed and helped level the ground and build the fishing camp. "If the Indians had all the houses or tents they need in that place and the Loggers would not interfere in any way with the Indians, I think it would be a good thing to have them there as friends of the Indians," he said. He noted that the Indians would not catch fish there but only receive the stripped salmon carcasses; so the loggers' presence would not interfere with fishing. ${ }^{81}$ Davis did not indicate what effect the logging operation would have on the salmon trying to reach the White Salmon River.

In 1949, the Umatilla Reservation had a new superintendent, Earl Wooldridge, and the same impasse over a new resolution approving the Lone Pine site. On January 19, Swindell, the attorney for the Indian Office, wrote Wooldridge urging action. The Corps had been calling asking about the status, putting Swindell "in an embarrassing position." In a stern admonition to Wooldridge, Swindell wrote, "I might point out that the entire program of the acquisition of the other sites is being delayed by reason of the 
failure of the Umatilla authorities to take action. It is hoped that at the next meeting of the Tribal Business Committee a resolution along the lines of the one enclosed herewith passed by the Warm Springs Tribal Council may be obtained."

On February 8, the Yakima Tribal Council adopted a new resolution incorporating the legal description of the agreed on Lone Pine site ${ }^{83}$ The lack of action to acquire any sites in addition to White Salmon continued to frustrate the river people. On February 15, District Director Pryse of the Indian Office, wrote to John Baker, a Hood River attorney who apparently had inquired about the sites on behalf of Henry Charley. "Because of the intervention of the war years the project was never carried to completion," Pryse wrote. "It was reopened about two years ago by the War Department and ever since that time we have been endeavoring to obtain the consent of the Indians to the substitution at the request of one of their own number of a new lieu site for the one originally agreed upon." He said the $\$ 50,000$ was still available and within the past two weeks the Corps had said it was still prepared to go ahead. Pryse also explained why correspondence went to the Yakima, Warm Springs and Umatilla reservations and not to the Columbia River Indians. “... the so-called Mid-Columbia River Indians ... are, however, enrolled and under the jurisdiction of the superintendent of one of those three reservations." The Klickitat Tribe, to which Charley belonged, was one of 14 listed as signing the Yakima Treaty and was considered a part of the Yakima Nation, he said. ${ }^{84}$

To the Indians everything along the river seemed uncertain. Nora Evans of Hood 
River wrote Shotwell, the Yakima superintendent, July 25 asking if Indians could still fish on the island at Cascade Locks where they had fished "every season since I can remember." 85 The question was turned over to Davis to answer and he responded that the only restriction was within five miles of Bonneville Dam, which included Cascade Locks, but he recommended that she check with the state of Oregon for other regulations before engaging in commercial fishing at any site. ${ }^{86}$

The files contain no record of Umatilla tribal action, but on September 30, Lt. Col. D.A. Elliget, Acting District Engineer for the Corps, wrote John Whiz of the Celilo Fish Committee that "the acquisition of all replacement fishing sites will be undertaken in the immediate future." He said he expected the acquisitions to be completed in time for a meeting with the Indians early in 1950 to discuss the "nature and extent of improvements" on the sites. ${ }^{87}$ 


\section{NOTES}

1. M.A. Johnson, letter to C.G. Davis, Jan. 8, 1940, Box 10, Field Agent, The Dalles, Ore., 1939-53, 155 E-K, Bureau of Indian Affairs, Record Group 75, National Archives - Pacific Northwest Region, Seattle.

2. J.R. Venning, letter to M.A. Johnson, Feb. 3, 1940, Box 11, Field Agent, 155 K-S, BIA, RG 75, NA-Seattle.

3. Johnson, letter to Commissioner of Indian Affairs, Feb. 8, 1940, Ibid.

4. Don E. Meldrum, letter to C.G. Davis, Apr. 30, 1940, Ibid.

5. C.G. Davis, letter to M.A. Johnson, Dec. 2, 1940, Box 110, Field Agent, The Dalles, Ore., 1939-49, Bureau of Indian Affairs, Record Group 75, National Archives Pacific Northwest Region, Seattle.

6. Meldrum letter to M.A. Johnson, Dec. 5, 1940, Box 11, Field Agent, 155 K-S, BIA, RG 75, NA-Seattle.

7. James Jim, letter to M.A. Johnson, Ibid.

8. Johnson, letter to James Jim, Dec. 21, 1940, Ibid.

9. Johnson, letter to Isabelle Bullard, Mar. 14, 1941, Ibid.

10. Johnson, letter to Don E. Meldrum May 24, 1941, Ibid.

11. Meldrum, letter to M.A. Johnson, May 28, 1941, Ibid.

12. Davis, letter to M.A. Johnson July 21, 1941, Ibid.

13. Davis letter to Johnson Sept. 15, 1941, Box 10, Field Agent, 155 E-K, BIA, RG 75 , NA-Seattle.

14. Johnson, letter to Commissioner of Indian Affairs, Sept. 22, 1941, Ibid.

15. C.R. Moore, letter to Division Engineer, North Pacific Division, Army Corps of Engineers, Dec. 8, 1941, Corps of Engineers, Portland District files. 
16. Meldrum, letter to John W. Fishburne, Dec. 16, 1941, Ibid.

17. Edward G. Swindell Jr., letter to M.A. Johnson Sept. 22, 1941, Box 11, Field Agent, 155 K-S, BIA, RG 75, NA-Seattle.

18. Robert P. Patterson, letter to Secretary of the Interior, Jan. 1, 1942, Corps of Engineers, Portland District files.

19. W. Barton Greenwood, letter to M.A. Johnson, Feb. 23, 1942, Box 11, Field Agent, $155 \mathrm{~K}-\mathrm{S}, \mathrm{BIA}, \mathrm{RG} 75$, NA-Seattle.

20. Charles E. Jackson, memo to Commissioner of Indian Affairs, July 6, 1942, Box 9, Field Agent, The Dalles, Ore., 1939-53, 155 A-D, Bureau of Indian Affairs, Record Group 75, National Archives - Pacific Northwest Region, Seattle.

21. Minutes, Celilo Fish Committee, Sept. 25, 1942, Box 11, Field Agent, 155 K-S, BIA, RG 75, NA-Seattle.

22. Minutes, Yakima Tribal Council, Oct. 16, 1942, Ibid.

23. Yakima Tribal Council-Indian Fishermen Committee, resolution, Oct. 23, 1942, Ibid.

24. Johnson, letter to Don E. Meldrum, Oct. 26, 1942, Ibid.

25. Swindell, letter to the Commissioner of Indian Affairs, Aug. 26, 1942, accompanying the July 1942 report, from U.S. Forest Service files, Portland, Ore.

26. Davis, letter to M.A. Johnson, Mar. 3, 1942, Box 9, Field Agent, 155 A-D, BIA, RG 75, NA-Seattle.

27. Johnson letter to C.G. Davis, Mar. 16, 1942, Ibid.

28. Davis, letter to M.A. Johnson, Mar. 12, 1943, Box 11, Field Agent, 155 K-S, BIA, RG 75, NA-Seattle.

29. Johnson, letter to Don E. Meldrum, Mar. 15, 1943, Ibid.

30. Meldrum, letter to M.A. Johnson, Mar. 23, 1943, Ibid.

31. Norman M. Littell, letter to Oliver Malm, July 24, 1943, Corps of Engineers, Portland District files. 
32. Robert A. Lovett, letter to Secretary of the Interior Aug. 23, 1943, Box 114, Yakima Indian Agency, 1925-67, 002-036.1, Bureau of Indian Affairs, Record Group 75, National Archives - Pacific Northwest Region, Seattle.

33. Walter V. Woehlke, letter to Thomas Yallup, Sept. 7, 1943, Ibid.

34. J.W. Elliott, letter to T. Leland Brown, May 4, 1944, Ibid.

35. United Press, Mar. 2, 1945, clipping from unidentified newspaper, Box 12, Field Agent, The Dalles, Ore., 1939-63, 155 U, Bureau of Indian Affairs, Record Group 75, National Archives - Pacific Northwest Region, Seattle.

36. Excerpt from Public Law 14, Chapter 19, 79th Congress, from Corps of Engineers, Portland District files.

37. Minutes, Celilo Fish Committee, Apr. 4, 1945, Box 12, Field Agent, 155 U, BIA, RG 75, NA-Seattle.

38. William Zimmerman Jr., letter to Mr. Simmons Jan. 11, 1946, Box 114, Yakima Indian Agency, 1925-67, 002-036.1, Bureau of Indian Affairs, Record Group 75, National Archives - Pacific Northwest Region, Seattle.

39. Robert P. Patterson, letter to Secretary of the Interior, undated but responding to a Feb. 20 Interior Department inquiry, Ibid.

40. Davis, letter to L.W. Shotwell, Jan. 25, 1946, Box 10, Field Agent, 155 E-K, BIA, RG 75, NA-Seattle.

41. L.W. Shotwell, letter to C.G. Davis, Jan. 29, 1946, Ibid.

42. J.M. Jessup, letter to Henry Charlie [sic], Nov. 6, 1946, Box 11, Field Agent, 155 K-S, BIA, RG 75, NA-Seattle.

43. Henry Charley, letter to Superintendent Shotwell, Mar. 10, 1947, Box 114, Yakima Agency, 002-036.1, BIA, RG 75, NA-Seattle.

44. Abstract of letter and Davis's actions, Mar. 13, 1947, Box 11, Field Agent, 155 K-S, BIA, RG 75, NA-Seattle.

45. Davis letter to L.W. Shotwell, Mar. 18, 1947, Ibid.

46. Davis, notice, Mar. 18, 1947, Ibid. 
47. Kenneth R.L. Simmons, letter to William Zimmerman, Jr., Mar. 19, 1947, Ibid.

48. Davis, report on meeting of Indians, Indian Office representatives and Corps of Engineers officials, Mar. 27, 1947, Box 12, Field Agent, 155 U, BIA, RG 75, NASeattle.

49. E. Morgan Pryse, letters to L. W. Shotwell, J.W. Elliott and Henry Roe Cloud, Apr. 4, 1947, Box 11, Field Agent, 155 K-S, BIA, RG 75, NA-Seattle.

50. Davis, outline, Mar. 27, 1947.

51. Davis, unmailed letter to L.W. Shotwell, Mar. 31, 1947, Box 12, Field Agent, 155 U, BIA, RG 75, NA-Seattle.

52. Davis, letter to L.W. Shotwell, Apr. 1, 1947, Ibid.

53. Columbia River Indians, petition to Yakima Tribal Council, April 12, 1947, Box 114, Yakima Agency, 002-036.1, BIA, RG 75, NA-Seattle.

54. Swindell, letter to Kenneth R.L. Simmons, Apr. 3, 1947, Ibid.

55. Elliott, letter to E. Morgan Pryse, Apr. 11, 1947, Ibid.

56. Yakima Tribal Council resolution, Apr. 24, 1947, Box 11, Field Agent, 155 K-S, BIA, RG 75, NA-Seattle.

57. Shotwell, letter to E. Morgan Pryse, May 2, 1947, Ibid.

58. Guy Cordon, telegram to T. Leland Brown, Apr. 11, 1947, Box 114, Yakima Agency, 002-036.1, BIA, RG 75, NA-Seattle.

59. Brown and Van Vactor law firm letter to E. Morgan Pryse, Apr. 12, 1947, Ibid.

60. Davis, outline, Mar. 27, 1947.

61. Dick Darnielle, letter to Caples Dave, May 9, 1947, Box 114, Yakima Agency, 002-036.1, BIA, RG 75, NA-Seattle.

62. Pryse, letter to J.W. Elliott, May 23, 1947, Ibid.

63. Swindell, memo to Superintendent Shotwell, July 26, 1947, Box 11, Field Agent, $155 \mathrm{~K}-\mathrm{S}, \mathrm{BIA}, \mathrm{RG} 75$, NA-Seattle. 
64. Pryse, letter to L.W. Shotwell and Henry Roe Cloud, Oct. 6, 1947, Box 114, Yakima Agency, 002-036.1, BIA, RG 75, NA-Seattle.

65. Mary U. Lane, letter to C.G. Davis, June 12, 1947, Box 11, Field Agent, 155 K-S, BIA, RG 75, NA-Seattle.

66. Davis, letter to Mary Lane, July 1, 1947, Ibid.

67. Davis, letter to L.W. Shotwell, July 7, 1947, Ibid.

68. Pryse, letter to District Engineer, Corps of Engineers, July 30, 1947, Ibid.

69. Davis, letter to Mary Lane, Aug. 5, 1947, Ibid.

70. Davis, letter to J.W. Elliott, Sept. 30, 1947, Ibid.

71. Henry Roe Cloud, letter to L.W. Shotwell, Jan. 21, 1948, Box 114, Yakima Agency, 002-036.1, BIA, RG 75, NA-Seattle.

72. Minutes, Celilo Fish Committee, Apr. 1, 1947, Box 12, Field Agent, 155 U, BIA, RG 75, NA-Seattle.

73. Swindell, letter to Henry Roe Cloud, July 7, 1947, Box 11, Field Agent, 155 K-S, BIA, RG 75, NA-Seattle.

74. Roe Cloud, letter to C.G. Davis, July 21, 1948, Ibid.

75. Davis, memorandum to L.W. Shotwell, July 23, 1948, Ibid.

76. Pryse, letter to Henry Charley, Aug. 6, 1948, Box 114, Yakima Agency, 002036.1, BIA, RG 75, NA-Seattle.

77. Davis, proposal to exchange Tenino site for Lone Pine site, Oct. 1, 1948, Box 11, Field Agent, 155 K-S, BIA, RG 75, NA-Seattle.

78. Celilo Fish Committee minutes, Oct. 22, 1948, Ibid.

79. Warm Springs Tribal Council Resolution, Nov. 5, 1948, Ibid.

80. Complaint, U.S. v. Rogers Logging Co., U.S. District Court, Western District of Washington, Southern Division, No. 1114, copy in Box 11, Field Agent, $155 \mathrm{~K}-\mathrm{S}$, BIA, RG 75, NA-Seattle. 
81. Davis, letter to L.W. Shotwell, June 18, 1948, Ibid.

82. Swindell, letter to Earl Wooldridge, Jan. 19, 1949, Ibid.

83. Yakima Tribal Council, resolution, Feb. 8, 1949, Ibid.

84. Pryse, letter to John Baker, Feb. 15, 1949, Box 114, Yakima Agency, 002-036.1, BIA, RG 75, NA-Seattle.

85. Nora Evans, letter to L.W. Shotwell, July 25, 1949, Box 10, Field Agent, 155 E$\mathrm{K}, \mathrm{BIA}, \mathrm{RG} 75$, NA-Seattle.

86. Davis, letter to Nora Evans, Aug. 3, 1949, Ibid.

87. D.A. Elliget, letter to John Whiz, Sept. 30, 1949, Box 11, Field Agent, 155 K-S, BIA, RG 75, NA-Seattle. 


\section{CHAPTER IV: THE FIFTIES - HALF A LOAF, OR LESS}

\section{Moving On}

Congress, as it began full scale development of the Columbia River Basin in the 1950s, took note of the lieu sites. An appendix to the 1950 Rivers and Harbors Act, devoted a chapter to "The Indian Fishery Problem." The discussion once more asserted that the Warm Springs Tribes have no fishing rights on the Columbia as a result of the 1865 treaty. The argument was that Congress had ratified the treaty and the courts could not nullify it even if it were obtained by fraud. Despite the Congressional note, the federal agencies continued dealing with the Warm Springs over the sites. The document did recognize the rights of the Mid Columbia Indians despite their lack of a treaty on grounds the rights were inherent in their tribal sovereignty and had never been relinquished.

"Development of the river has or may affect 14 usual and accustomed fishing sites," the document stated, with 10 of those on the Columbia. "The first six sites are within the Bonneville pool and are to be developed in lieu of sites inundated when that project was constructed." The sites listed were Tenino and Herman Creek on the Oregon side and Big Eddy, Big White Salmon, Little White Salmon and Wind River on the Washington side.

Under the heading "Alternates to fishing," the report stated:

Alternate fishing sites to replace those inundated must be established - if need be by artificial means, or the Indians paid just compensation for the sites taken. Attempt to pay the Indians money for complete abandonment of their fishing rights need be resorted to only in extremes. Some spokesmen for the 
Indians state that the Indians do not want money, or any alternate economic opportunities, but prefer, in fact will insist, on the right to continue to live to the millennium [which then seemed far away] by the means and in the manner by which they have existed throughout the centuries. It would appear that the long-range solution to the problem lies in the integration and assimilation of these people into society at large.

The report concluded: "In the meantime, the Indians must be paid just compensation for any taking of their property rights, or provided the equivalent thereof by other means." But nothing happened for a year.

On April 15, 1951, Edward G. Swindell, Jr., area counsel for the Office of Indian Affairs, assured James Jim, an Indian who lived on the river shore, that the issue of the lieu site at Underwood "is being actively prosecuted." He added, "It is unfortunate, of course, that because of World War II steps looking to acquisition of the lieu lands had to be deferred (at this point, the war had been over nearly six years). However, as previously stated this matter is under active consideration and no doubt will be completed in the not too distant future."2

Three days later, half a dozen of the Indians who had lost homes to Bonneville's backwater met with two representatives from the Corps of Engineers at the Yakima Indian Agency in Toppenish. There is no indication of who made the record of the meeting, which was headed, "Meeting for the discussion of the proposed purchase of homesites by the War Department, for Indians who were flooded out by the Bonneville Dam." According to the record, the discussion centered on what buildings should be erected with mention given to "kitchen or living quarters and separate buildings for drying fish." A tentative number of drying sheds for each site was given: 6 at 
Underwood, 12 at Cooks (Little White Salmon), 10 at Big White Salmon and 5 at Wind River. A.D. Stanley of the War Department (although the War Department was merged into the new Defense Department in 1947, documents in agency files continue to refer to the War Department for a number of years) told the Indians the 23-acre Wind River site "was already acquired and can be used by the Indians at any time." The group agreed the Army should buy the site on Mrs. Jessup's property - Little White Salmon - "providing such improvements required would be installed by the War Department."

On May 1, B.L. Price, chief of the real estate division for the Corps of Engineers Portland District, gave the Area Director of the Office of Indian Affairs (still E. Morgan Pryse) a detailed report of the status of the lieu sites:

1. Wind River, four acres acquired from Anna Frances Monaghan; condemnation proceedings for 19.06 acres owned by Amelia May St. Martin filed in November 1950; because "a judge is not regularly available" the case may not be tried before 1952 [this would seem to contradict Stanley's statement at Toppenish on April 16 that the site already had been obtained]; after the condemnation was filed, the land was logged of all merchantable timber.

2. Big White Salmon, 4.19 acres acquired July 8, 1942; condemnation filed March 1950 against Skamania County for a road on the tract.

3. Little White Salmon, 16.62 acres subject of negotiations with Mrs. Mary Jessup. After years of urging the Army to buy the land, now, "She is reluctant to sell this land for use as an Indian camp site," Price noted.

4. Big Eddy, 224.61 acres being acquired by condemnation from the state of Washington with trial set for May 15, 1951; the title would be accepted subject to access to The Dalles Bridge and, when The Dalles Dam is built, will be taken for that project.

5. Lone Pine, nine acres under negotiation with Seufert Brothers Co. "Mr. 
Seufert is opposed to the acquisition of this land by the Government for an Indian camp site."

6. Herman Creek, three tracts of land with negotiations delayed "for possible Federal legislation, a Court decision, or a legal opinion of some recognized authority in respect to Indian fishing rights in Herman Creek below the state fish hatchery." The private owner of one tract "was opposed to the purchase of her land by the Government in 1949" and the Oregon Fish Commission "is vigorously opposed" to an Indian fishing site there, near a state hatchery. ${ }^{4}$

\section{Complications}

The Yakima Tribes touched off a flurry of correspondence, including what seems to be little used teletype and airmail, with a May 28 request to meet with Corps of Engineers officials in Washington. "Wire reports sites purchased and briefly outline unfilled commitments," the Washington headquarters of the Office of Indians Affairs ordered Pryse, the agency's Portland Area Director. The teletype message was signed only "Critchfield" without a first name or title. ${ }^{5}$ Pryse responded with a teletype and an airmail letter, both on May 29. The situation had changed little since B.L. Price's report of May 1, but Pryse added the appraised value of each site and his own estimation of complications. "No complications expected," he said of Big White Salmon. Little White Salmon was appraised at $\$ 2,675$ and "complicated by Fish and Wildlife water grade road to new hatchery." Four acres at Wind River were acquired for $\$ 500$ and the remaining tract, subject to condemnation proceedings, was valued at $\$ 1,220$. Big Eddy was condemned for $\$ 3,700$ on May 15,1951 , "but complicated by the fact Dalles Dam spillway and new highway bridge will interfere with or destroy campsite value." Lone Pine, valued at $\$ 3,750$, was "complicated by proposed 20 foot 
road to water level." Herman Creek, where the three tracts were appraised for a total of $\$ 5,892$, was on hold because of the opposition of the state of Oregon which "now refuses to donate salmon carcasses to the Indians." The Corps of Engineers' total administrative expense had been $\$ 6,233$. Total appraised value of all sites was $\$ 19,248$. "Latter figure probably inadequate," Pryse said, "in view of intervening rights since appraisal, namely road and log dumping areas leased to logging operations at Wind River and Little White Salmon sites." He put the minimum for meeting the original commitment to the Indians at $\$ 25,670$ to replace the 37 fishing and camping sites inundated in the Bonneville pool. In addition, the leased rights at Wind River and Little White Salmon probably would cost $\$ 30,000$. The Corps was not then able to estimate its costs to install the promised site improvements. "Importance and value of six 'lieu’ sites enormously enhanced if Dalles Dam constructed," Pryse said. ${ }^{6}$

In a letter the same day, Pryse added a little information, some history and some political cover for the actions of his own office. "During the period this Area Office has been in existence we have been in constant touch with local representatives of the Real Estate Division of the Corps of Engineers and a number of meetings were held with the Indians," Pryse wrote. "It is indeed unfortunate that since the original understandings were arrived at some time in the late 1930's [sic] actual acquisition of the 'lieu' sites in question was not accomplished." Outlining the delays for appropriations, the war and reaffirmation of the Indians' desires, Pryse said that "steps looking to the acquisition of the sites have been progressing steadily but admittedly 
slowly."7

Pryse, the complete bureaucrat, also wrote to Col. D.S. Burns, the Corps' District Engineer, summarizing "solely for the record" what he had told the commissioner. He also told Burns there was an assumption that after site acquisition was completed "a further meeting will be had to determine the nature, extent and probable cost of the improvements ..." Pryse then bundled up all the correspondence and sent copies to the superintendents of the three Indian agencies, promising to keep them advised of any developments and asking Yakima Superintendent Perry E. Skarra for a report from the Yakima delegation in Washington after its members returned. ${ }^{9}$

On June 8, the Commissioner of Indian Affairs, D.S. Myer, wrote the chairman of the Yakima Tribal Council, without naming him and routing the letter through Pryse and Skarra. The letter served only to record Myer's view of the meeting between the Yakima delegation and the Corps, which took place in Washington sometime between May 29 and June 8. The purpose of the meeting, "as stated by the delegates, was to obtain the assistance of the Washington office of the Corps of Engineers in securing completion of the program," Myer wrote. "There was no disagreement on the part of anyone in the meeting concerning the Corps' responsibility to acquire the six sites agreed upon, to make the improvements, and to acquire the rights of way and provide roads for ingress and egress to the sites." He said the Corps "expressed some doubt" that the $\$ 50,000$ appropriated would cover all the costs to buy and improve the sites. "The Corps of Engineers also stated that it may be necessary to request the 
Congress to appropriate additional funds," he said. The Corps suggested the Indians might want to give priority to putting improvements on "some of the tracts already acquired" and possibly another meeting could be held to "determine priority in use of the money."10

Pryse, who always seemed to be making sure everyone knew that he was not responsible for the in lieu site delays, wrote his agency superintendents again on June 19 calling yet another meeting on the issue. "We are pressing this matter," he said, and had made arrangements with a Corps official for yet another inspection of the sites by the Indians to be followed by a meeting "so that the Indians may express their current views to the authorities of the Corps of Engineers." He added, "Please accept my assurance that this is not just another meeting. We propose to obtain some definite and affirmative action in the immediate future in regard to these sites."

So seven members of the Celilo Fish Committee, representing the Warm Springs, Yakima and Umatilla Tribes, once more visited the sites on July 19 accompanied by 12 representatives of the Indian Service and The Corps of Engineers. The next day the group, with the addition of two Indians and a representative of the U.S. Fish and Wildlife Service, met at The Dalles. Two officials from the Corps - Lt. Col. J.W. Sloat, the District Executive Officer, and A.D. Stanley, a civilian, outlined the status of each site. Little had changed since the first of May, but Stanley brought up some additional problems.

At Lone Pine, he said, obtaining a satisfactory water supply would be a problem 
although "not too great." The state will not permit fishing in Herman Creek, raising a question of whether the site would be worthwhile. The question at Wind River was whether the logging interest should be eliminated. That might be expensive, Stanley said. The question at Little White Salmon was whether to go ahead with the original site, which had been affected by logging and construction of a road, or to acquire an alternate site. Big White Salmon also had roads - one legal, one illegal - and the issue was whether to accept the land with roads or demand their elimination. Only Big Eddy seemed entirely without problems, and that would soon end. In the course of discussing the often-repeated explanations for the delay in acquiring the sites, Stanley said that the Umatilla Tribes still had not consented to the substitution of the Lone Pine site for Tenino. Stanley also told the Indians that the Indian Service did not want to assume responsibility for any of the sites until the Corps had acquired all of them.

\section{Backing Away}

This meeting appears to mark the point at which the Corps of Engineers began to back away from the 1939 agreement. Minutes of the meeting give this account:

Col. Sloat again took the floor to summarize the position of the Corps of Engineers. He pointed out that it would be unwise and contrary to the best interests of all parties to acquire and develop all the proposed sites regardless of cost until the appropriate Indian tribes were advised of current conditions conditions in many instances being greatly changed since 1939 when the sites were first recommended. He pointed out that at that time acquisition of the sites for the exclusive use of the Indians was recommended. In some instances it might now be advisable, he said, to acquire certain tracts subject to other interests, such as, for instance logging and booming rights. Also, it might possibly be that the Indians might prefer that the Corps of Engineers complete the acquisition of one or more sites and improve these sites with available funds and turn them over to the Indian Service without waiting until all of the sites 
were acquired and improved.

Louis McFarland of the Umatilla Tribe then explained why the Indians were suspicious of any agreement with Government officials (the minutes do not include his explanation) and suggested the discussions might require several days. However, Frank Suppah of the Warm Springs Tribe said the fish committee should make decisions that day because postponing a decision would only further delay the time the Indians could use the sites. Any agreements should be in writing, he said. McFarland, Ralph McBean of the Umatilla Tribe and Hazel Quiempts of the Celilo Tribe all made statements that the $\$ 50,000$ available for the sites should be used to benefit Indians who lost fishing sites as a result of the Bonneville Dam construction. As the afternoon session opened, Henry Charley recommended that the sites be improved as the land was acquired because, he said, "the Indians would never get anywhere if they had to wait until all six locations were acquired and improved prior to occupancy." Charley, the Fish Committee secretary, said the $\$ 50,000$ was only an estimate of cost and the War Department's responsibility would not end until the sites were purchased and improvements made. He listed those improvements as rebuilding the drying houses and providing living quarters, leveling the ground, providing running water, incinerators and sanitary facilities. Sloat, reading a portion of the law, told the committee that the $\$ 50,000$ was appropriated to purchase sites. But if Sloat was reading from the 1945 act that authorized the $\$ 50,000$, he skipped a point. The act states "to acquire lands and provide facilities" and that "lands and facilities" are to be 
transferred to the Secretary of the Interior "for the use and benefit of the Indians."12

Despite his statement that the money was only for land purchase, Sloat told the committee the Big White Salmon site was available for improvements. The Wind River, Little White Salmon and Lone Pine sites could be acquired "within a period of three months after receipt of specific approval from the various Indian tribes." He said it would be impossible to indicate how long construction of the improvements would take.

The discussion ranged over various possible actions concerning the sites and touched on fishing rights and potential site loss from construction of the proposed The Dalles Dam - "which is contrary to the wishes of the Indians." Thomas K. Yallup of the Yakima Reservation said the War Department in Washington had assured him it would ask for more money if the $\$ 50,000$ was not enough to complete the agreement with the Indians. He urged early compliance by the Corps with the agreement "to restore the drying shacks, houses, homes and other buildings that the Indians lost when Bonneville Dam was built." The record does not indicate who kept the minutes of this meeting, but the bureaucratic style of writing indicates it was one of the government representatives, probably from the Indian Service. At any rate, it is likely that Yallup was definite about "the agreement." The minute taker wrote it as "the (alleged) agreement," again indicating the government was backing away from what had long been the Indians' understanding of the deal. Wilson Charley reported that Thomas Yallup had learned during his visit to Washington that the Corps of Engineers in 
Washington had no copy of the 1947 agreement between the tribes and the Corps and Charley said he would send copies there. In fact, no copies of any agreement in either 1939 or 1947 were in any of the files examined and officials of both the Corps of Engineers and the Bureau of Indian Affairs have told this writer they have been unable to find any copy of an agreement at any time. I suspect there never was an agreement as such but that the tribal resolutions accepting terms of government proposals were considered agreements.

Finally, the committee approved, by a vote of $8-0$, a resolution outlining the Indians' position on the sites. The resolution noted that "certain physical changes have taken place since the sites were originally accepted" and "it would seem necessary to alter previous action in the matter." The resolution made a series of recommendations:

That the Lone Pine, Wind River and Big White Salmon sites "remain as previously agreed on."

That the acquisition of Herman Creek be held in abeyance while the Corps sought a more suitable site.

That the Little White Salmon site be changed to eight acres adjacent to the river and south of the state highway and railroad near Cook, Wash.

That the Big Eddy site be held in abeyance pending further investigation.

The resolution also set priorities for development of the sites with Big White Salmon at the top followed by Little White Salmon, Lone Pine and Wind River. It added a further resolution - "that the Fish Committee feels that the War Department should replace the living quarters and drying sheds destroyed by the Bonneville Pool in addition to other facilities agreed on."13 The Yakima Tribal Council met four days later and approved the fish committee resolution with the addition of a post script, asking that the Big Eddy site be acquired as number 5 on the priority list. ${ }^{14}$ 
On August 3, Skarra, the Superintendent of the Yakima Indian Agency, wrote Area Director Pryse of the Indian Service in an effort to head off what he saw as an effort by the Corps of Engineers to shift responsibility for construction on the fishing sites to the Indian Service. Skarra said the amount of money left from the $\$ 50,000$ after the purchasing the sites "would be inadequate to construct the improvements needed by the Indians." He suggested the Corps would be in a better position than the Indian Service to obtain the additional appropriation needed. Skarra also saw controversy coming:

There is a difference of opinion between the local representatives of the Corps of Engineers and the Indians regarding the nature and type of improvements to be constructed. The Indians believe that the Washington Office of the Engineers has committed itself to providing living quarters and drying sheds, while the District Office of the Engineers believe that the improvements consist only of sanitary facilities, leveling of ground and providing water. ${ }^{15}$

An undated, unsigned handwritten chronology of the in lieu site issue from July 12, 1939, to October 12, 1951, lists a letter dated April 6, 1950, from the District Engineer to the Division Engineer "that indicates it is intended to transfer any balance of $\$ 50,000$ after sites have been acquired to Indian Service for improvements. ${ }^{16}$

Three people from the Corps, including Stanley, the civilian who attended the July 19 meeting, met with five members of the Yakima Tribal Council and tribal fish committee on December 7 to decide placement of water, incinerator and sanitary facilities at Big White Salmon and Wind River. Stanley told the Yakima delegation that those were the only improvements that would be considered "at this time ... as originally contemplated and provided for in the resolutions adopted by Tribal Councils 
or Business Committees of the Yakima, Warm Springs and Umatilla Reservations in 1939." Filling the Big White Salmon site to provide more building space would be too costly, $\$ 40,000$, Stanley said, and he suggested acquiring a nearby site if additional money was appropriated. ${ }^{17}$

\section{Stop Everything}

Despite the Corps of Engineers' assurances that work would soon be under way, the first communication of 1952 announced that all work on the sites had been stopped. The reason cited by Lt. Col. James W. Sloat, the Corps' District Executive Officer, was that there were differences in the resolutions adopted by the tribes after the July 20 meeting. Sloat's memo of February 7, 1952, to the Division Engineer (who was not named in the communication) also cited the tribes' "failure to jointly concur with the recommendations of the Celilo Fish Committee in respect to the construction of facilities." ${ }^{18}$ It is not clear exactly how the resolutions differed since only the Yakima document appeared in any of the files searched. However, a later letter states that the Umatilla resolution, which seemed to cause the problem for Sloat, had stated that all sites should be purchased before improvements were made on any and that equal amounts be spent improving each site. ${ }^{19}$ Why the Umatilla resolution became an issue in January of 1952 is not clear; Sloat must have been aware of it when he told the Yakima delegation on December 7, 1951, that work could begin soon on several of the sites.

Sloat's memo said planning for immediate construction had ceased "pursuant to 
instructions" contained in a January 10,1952, memo from an unidentified higher authority than the District Engineer. It is not, however, clear who ordered the halt or why - except that the tribes' resolutions did not completely match. There is no evidence that there was any disagreement over at least four of the sites nor that the Umatilla Tribes' reference to delaying construction until all sites had been acquired included the two doubtful sites. Reasons for the Corps' action more likely will be found in the politics of the times. The Corps was getting ready to break ground for The Dalles Dam in 1952 and was preparing to negotiate with the Indians over the loss of the Celilo fishery that would result. As Donald L. Parman reported in 1992, the demand for electricity in the Northwest transcended partisan politics, giving construction of dams a far higher priority than fish-related problems. At the same time, "mounting congressional hostility toward the BIA signaled the beginning of the termination policy and greater indifference for Indian welfare. ${ }^{120}$ At the same time the states were hostile to Indian fishing, especially in Washington. "The Indian fisheries seem never to have been looked upon by the state as genuinely legitimate fisheries," the American Friends Service Committee reported in 1970. "The view of both the state and the Bureau of Indian Affairs seems to have been that Indian fishing, although legal, is a nuisance and an anachronism, something which should be expected to disappear in the course of events. ${ }^{21}$ A presidential election was under way in 1952 that would bring Dwight Eisenhower to the presidency, along with a policy designed to make Indians disappear. Between 1954 and 1962, Congress, responding to 
Eisenhower Administration policy, passed a dozen acts to terminate federal recognition of Indian tribes, among them the Klamaths and all the dozens of Western Oregon tribes. $^{22}$

Regardless of the reason, Sloat said planning for the in lieu site work had been halted and "further action will be held in abeyance pending receipt of approval" from the Division Engineer. However, he appeared to be seeking a way to continue. Sloat made a detailed report of expenditures so far and estimated future expenditures. Based on those figures he recommended that his office be given the go-ahead to construct water and sanitary facilities at one site on each side of the river - Big White Salmon and Lone Pine. "Construction of such facilities prior to the 1952 fall fishing season should indicate to the Indians, more than any other action which can be taken, that progress is being made in the acquisition and improvement of the Bonneville Indian Fishing Sites," he said. There was good reason, it appears, to impress the Indians with the government's sincerity. "Such action should also materially benefit pending negotiations with the Indians in respect to their fishing rights in connection with The Dalles Dam," Sloat added.

He said representatives of the District Engineer's office had met on January 17 with representatives of the Indian Service and the Yakima Tribes, telling them that construction of facilities was suspended. At that meeting, he said, it was determined that the Indian Service would contact the Umatilla Tribes' Board of Trustees for the purpose of determining the basis for the board's resolution of August 23, 1951, "and 
correcting any misunderstanding which they may have in respect to the aforementioned Resolution of the Celilo Fish Committee." Once more, pleading no known alternatives, Sloat asked for recommendations from the tribes whether to abandon acquisition of the Big Eddy and Herman Creek sites altogether or acquire an alternate site. It was clear where the Corps stood so far as the Herman Creek site was concerned. Sloat asked if the site should be acquired "regardless of the high cost and the State's objections ..." Attached to the memo was an accounting of money spent and the amounts needed for remaining acquisitions along with facilities construction at Big White Salmon and Lone Pine. The acquisition costs totaling $\$ 22,671$ included $\$ 5,700$ for Big Eddy, $\$ 1,751$ for Big White Salmon, $\$ 2,000$ for Alternate Little White Salmon, $\$ 2,220$ for Wind River, $\$ 10,000$ for Herman Creek and $\$ 1,000$ for Lone Pine. The cost of a shallow well, pit chemical toilets and an incinerator at Big White Salmon was listed as $\$ 1,800$; the cost for a 250 -foot-deep well and pit chemical toilets at Lone Pine was estimated at $\$ 5,973 .^{23}$

Sloat also wrote to Pryse, Area Director of what had been renamed the Bureau of Indian Affairs, about the decision not to proceed with construction. "Considering the conflicting recommendations of the various tribal councils involved, it is the present view of the Office, Chief of Engineers, that the funds now available from the original $\$ 50,000$ should be used to complete the acquisition of the land for all six of the sites prior to the expenditure of any money for construction purposes," he wrote.

Reversing a long-stated policy, Sloat added, "The Office, Chief of Engineers, 
has further indicated that it will not seek additional authority or funds for construction purposes at this time." Because Big Eddy would be required for The Dalles Dam, he said the Indians must decide on an alternate site or decide to eliminate that site. "The Indians will be permitted to use portions of the Big Eddy site for fishing purposes until such time as their activities interfere with the construction of the dam," he said. $\mathrm{He}$ also asked for a decision on immediate acquisition of Herman Creek, an alternate site or abandoning that site too. Obviously, elimination of both those sites would reduce the Indians' replacements for 37 lost sites to four. There were no known alternates to Big Eddy and Herman Creek, he said, but the Corps would be pleased to check. ${ }^{24}$ Pryse responded by forwarding copies of Sloat's letter to the tribes and adding the engineer's concerns to the agenda for a meeting of the Celilo Fish Committee being called for other reasons. He said he would ask members of the tribal councils from Yakima and Warm Springs and the board of trustees from Umatilla to attend "in order to form a unified approach to the problem and thus present a unified answer to the Corps. ${ }^{25}$ There is no evidence in the files that anything changed. The meeting eventually was set for April 3. However, the Indians had no known alternatives to the Big Eddy site, which would soon be taken for The Dalles Dam, or Herman Creek, which the Corps seemed determined to avoid buying. The Corps then avoided doing any work on the other sites on grounds it needed new decisions on Big Eddy and Herman Creek.

Meanwhile, on March 12, Wilson Charley, who was then chairman of the 
Yakima Tribes' game and fish committee, reminded the Corps that the previous July, at the Corps' request, the Celilo Fish Committee had taken a unanimous stand on the site locations. Then, he said, the Corps ceased work on all the sites. So, on a trip to Washington, D.C., the tribes' fish committee inquired about the cease work order and was told by the Corps in Washington that the order to stop work applied only to the Big Eddy site and that work on the other sites was supposed to proceed. Charley also told Stanley in his letter that the people affected by the Bonneville pool had rejected a proposed land exchange for the Big White Salmon site. In Charley's view, that cleared up any questions about what should be done. "The Yakima Fish Committee has worked hard towards completion of Bonneville pool campsite," he wrote, "therefore I pray and wish that the Corps of Engineers do the same. If there are any further minor details to be settled that Mr. A.D. Stanley should visit our Yakima Fish Committee at Yakima Indian Agency soon." 26

On March 21, the District Engineer, Col. T.H. Lipscomb, submitted his report on expenditure of funds for the site replacement showing a total of $\$ 41,251.34$ remaining of the $\$ 50,000$ appropriated. Only $\$ 500$ of the $\$ 18,771$ estimated for land costs had been spent. Under "remarks" he stated:

Reserve for contingencies, Item $7 \mathrm{e}$ [ $\$ 11,725]$, is to be utilized for unforeseen land payments and deficiency judgment awards in condemnation proceedings. In the event the contingency amount is not required for acquisition purposes, this amount will be available for improvement of the fishing sites with sanitary facilities, etc., as required. No development can be scheduled until acquisition is complete.

He added that the $\$ 50,000$ was expected to be adequate to acquire the land. He 
did not comment on the adequacy for making the promised improvements. ${ }^{27}$

In advance of the April 3 meeting, the Corps's Portland District asked the Division Engineer ${ }^{28}$ to clear up the apparently conflicting versions of what the Corps should be doing. "Completion of the acquisition of the Wind River, alternate Little White Salmon, Big White Salmon and Lone Pine sites is progressing and it is expected that the necessary Declarations of Taking [a part of the condemnation process] will be submitted in the near future," Sloat wrote. Acquisition of Big Eddy and Herman Creek was being "held in abeyance" still pending further re-affirmation from the tribes. In view of the soon-to-be-held meeting "and the alleged divergent instructions from the Office, Chief of Engineers representatives to the Indian delegation to Washington, D.C.," Sloat asked the division office to ask the Chief of Engineers for "further consideration of performing construction of minimum facilities at the Big White Salmon and Lone Pine sites" as the district office had recommended earlier. The matter was considered urgent enough to warrant the rare "air mail" label - although both district and division offices were in Portland. ${ }^{29}$

\section{A New Start}

On April 4, the Umatilla Tribes' Board of Trustees modified its resolution on the sites calling for enough money to be reserved to complete site purchases before construction of facilities began and for improvement of an equal number of sites on each side of the river. The action appeared to clear up the obstacles to further work cited by the Corps of Engineers. ${ }^{30}$ On March 24 the Office of the Chief of Engineers 
authorized the District Engineer to spend money for site improvement so long as enough was reserved to acquire the remaining sites. Despite the authorization, Sloat said in a September 11 letter to the Division Engineer that work on Big White Salmon had been delayed pending acquisition of Lone Pine on the Oregon side of the river. That acquisition was being delayed "to avoid certain severance damages." Both the Lone Pine site and adjacent land the Corps was acquiring for construction of The Dalles Dam were owned by Seufert Brothers and the land appraisal was then being reconsidered. However, Sloat said, work at Big White Salmon was being reactivated "in compliance with certain oral commitments" the Corps had made to the Yakima Tribes the previous year, assuring the Indians the work would be done before the 1952 fall fishing season. ${ }^{31}$

As the fall fishing approached, Skarra, the Superintendent of the Yakima Reservation, had asked the Corps about construction of the promised improvements. "The Indians are very disappointed" that nothing had been done, he said. ${ }^{32}$ The Corps did not respond until September 11, the same date as Sloat's letter to the Division Engineer. Then Sloat reported that construction of water and sanitary facilities at Big White Salmon had been reactivated and "drilling of the well should be started during the present month." Since the fishing season was already under way and buildings and their occupants would be in the way of construction other work would not begin until the season was over and the Indians were gone, he said. Part of the Little White Salmon site at Cooks, 3.14 acres, had been acquired on July 23, he said, and the 
Indians could take possession. The Wind River site should be available "in a few days" and Lone Pine condemnation should be completed by October 15. Construction at Wind River and Little White Salmon will not be started until all the sites have been acquired so that the Corps knows how much money it will have, he added. ${ }^{33}$

The Umatilla Tribes, in reporting their April resolution, also asked the Corps whatever happened to the Herman Creek site, saying that the Corps had agreed to inform the tribes if there were barriers preventing the acquisition. ${ }^{34}$ The Corps's Sloat replied on April 23 that he thought all the tribes had been informed about the problems of Herman Creek. None of these letters explain why all this wasn't resolved at the April 3 meeting. He listed the previous objections: no alternate site, high cost of the proposed site, no availability of fish carcasses from the state. The only alternate site located, he explained, was on state and Forest Service land near Eagle Creek used for overnight camping and other public recreation. That site "obviously is not available for purchase for an Indian fishing site," he wrote. Now, he said, there was another problem. The railroad (presumably the Union Pacific although he did not say) said it would require automatic signals for a crossing to reach the site and those would cost $\$ 10,000$. The Corps was awaiting instructions from the tribes, Sloat said. He suggested the problem might be resolved by eliminating the state-owned 1.22 acres at the foot of the bluff. That would leave five acres atop the bluff for camping and for drying fish. He sent copies of the letter to the Bureau of Indian Affairs and the other two tribes. ${ }^{35}$ The Warm Springs Tribal Council responded during a meeting in September 
with a resolution telling the Corps to acquire the Herman Creek site, including the disputed state land. ${ }^{36}$ There was no recorded response from the other tribes.

Two new complications arose in the fall of 1952 . The Warm Springs and Yakima Tribes filed claims for damages to the fish runs and their resulting loss of income as a consequence of construction of Bonneville Dam. The Warm Springs' claim included a claim for fishing sites submerged in the Bonneville pool. In discussing the status of the entire lieu site issue, Sloat suggested to the Division Engineer that the Indians could use or occupy any of the sites as soon as the government acquired title to the land without waiting for all the sites to be acquired, improved and turned over to the Department of Interior. He also noted that "there obviously is not sufficient money" remaining from the $\$ 50,000$ to finish the construction "to which the government is presently committed." He raised the possibility that, if the Justice Department found the Indians had a legitimate claim for loss of fishing sites, the Warm Springs might be entitled to damages for the period between the raising of the Bonneville Pool and the date the lieu sites were turned over to the Indians. He said the Warm Springs leaders had indicated they might withdraw the claim if they got a satisfactory settlement for the loss of fish at Celilo as a result of construction of The Dalles Dam. He said he concurred with the view of the Department of Justice that title to the Bonneville lieu sites should not be transferred to the Interior Department until the Indians dismissed their claims for Bonneville site losses. And, he suggested, perhaps no action should be taken toward acquiring the 
Lone Pine or Herman Creek sites for the Warm Springs Tribes or those tribes should not be permitted to use the two sites until the tribes' claim was withdrawn.

He reported the site status as of that date, September 16, as:

- Big Eddy, acquired but needed for construction of The Dalles Dam; therefore, no construction of facilities for the Indians; no alternate site approved.

- Big White Salmon, acquired; construction expected to begin that month.

- $\quad$ Alternate Little White Salmon, acquired except for license for railroad crossing and a portion of the railroad right of way, which were to be delayed until money was available for construction.

- Wind River, 4 acres acquired, 19.06 acres being acquired by condemnation, expected to be completed within a few days.

- $\quad$ Lone Pine, acquisition expected by October 15.

- Herman Creek, acquisition was to begin after new appraisals. ${ }^{37}$

\section{One More Blow, And Another}

Just when it seemed that the Indians might get one site improved, another blow fell. The Corps decided to raise the level of the Bonneville pool on October 11. The Corps issued a public notice on October 7, and on October 9, Jasper W. Elliott, a Corps administrative officer, stopped off at Underwood while en route to the Yakima Agency, "for the purpose of advising the Indians" they were about to be flooded. He found five women and the Robert Strong family there. Only two of the individuals were camped below the flood mark of 78 feet "and they expressed their intention to move immediately." Strong was loading fish and preparing to move to his home in Klickitat. When Elliott returned from Yakima, he found Bessie Quempts, Mrs. Henry 
Charley and Eliza Slim Jim loading their possessions on a truck to move to White Salmon. "Mrs. Josephone Washins apparently had taken no steps to move her small tepee from the danger zone although she assured me that relatives from Husum would arrive in time to remove her ahead of the higher water," Elliott reported. The people asked Elliott when work would begin on the site improvements and what would happen to their drying shacks and living quarters. "I advised them that I felt sure that they would be advised in advance of any plan to remove or destroy any of these facilities," he responded. ${ }^{38}$

In the last months of 1952 the Corps of Engineers made some small progress toward fulfilling the 1939 agreement but there were setbacks as well. A report, unaddressed and unsigned but written in the unmistakable military style of the Corps appears in the Portland District files under a January 26, 1953, date. It summarizes the status of the six sites:

- $\quad$ An incinerator had been installed and a well dug at Big White Salmon. "A pump will be installed, toilets will be constructed, and an inundated portion of the site will be filled at an early date."

- The government had obtained an "Order of Possession" for the Lone Pine site with the order to become effective "as soon as the required deposit into court is made."

- Both portions of the Wind River site had been acquired.

- $\quad$ Acquisition of the final piece of the Alternate Little White Salmon site still awaited determination of the construction needs, which in turn depended on the amount of money remaining for construction.

- The Big Eddy site already was being used for construction of The Dalles Dam and the Corps now had a new reason for delaying acquisition of an alternate 
site. No action was being taken, the report said, "due to the thinking that any rights of the Indians in respect thereto are included in the proposed settlement with the various Indian tribes involved, for loss of fishing rights in connection with The Dalles Dam."

- As for Herman Creek, action there was still pending "due to objections of the Oregon State Fish Commission." The Corps had not acted on the Warm Springs resolution requesting immediate acquisition of the site. Attached to the summary was a list of the appraised value of all the sites totaling $\$ 16,618$. The total included $\$ 3,700$ for the Big Eddy site, which already had been lost to The Dalles Dam construction.

The report also, apparently in response to some question missing from the files, included an extensive description of the Corps' negotiations with the Indians, explaining that the Yakima Tribes considered the Washington shore sites to be for their use and benefit while considering the Oregon shore sites the domain of the Warm Springs and Umatilla Tribes. "All of the Indians, especially those from the Warm Springs and Umatilla Tribes do not necessarily concur in this thinking," the unknown writer commented. The Corps has consulted only with the Yakima Indians on improvements for the Washington side sites and with the Umatilla and Warm Springs on Oregon side improvements, the report said. However, negotiations on selection and acquisition of sites have been conducted with the Celilo Fish Committee representing all the tribes, not with the Yakima Tribes alone. ${ }^{39}$

Sometime in the early months of 1953 the Corps found an alternate to the Herman Creek site it so assiduously avoided buying in the face of opposition from the state of Oregon. However, its new choice - at Cascade Locks - raised a real storm of criticism, mostly from a group of the town's residents, who brought Oregon 
Congressman Samuel H. Coon, a freshman Republican whose district included Cascade Locks, into the fray. At one point the Corps' District Engineer, Col. T.H. Lipscomb, asked the Cascade Locks group to name a new representative "who can refrain from engaging in personal abuse ..." ${ }^{, 40}$

The date of the Corps's decision to substitute government-owned land at Cascade Locks for the Herman Creek site, which was in private and state ownership, is not recorded. But on April 13 a delegation representing the City of Cascade Locks, the Port of Cascade Locks, and residents and businessmen from the community called on Lipscomb to get information and ask for time to prepare a protest. Lipscomb agreed to wait for the protest but made no commitment to withdraw the site. ${ }^{41}$

The group then fired the first shot in the controversy on April 22 in a letter to Lipscomb from Russel H. Nichols, chairman of the Cascade Locks Citizens Committee, Mayor V.F. Wigren and "secretary" John E. Springer (whether secretary of the committee or the town, the letter did not say). The letter raised five questions and asked that the proposal "be thoroughly aired so that the residents of the area, sports fishermen, and the Indians themselves will have full knowledge of exactly what is proposed." Denying any issue of racial discrimination or question whether the Indians should be compensated for the loss of their fishing sites, the letter concluded: "If there are those of the opinion that our objections to the establishment of an Indian fishing camp in the heart of our community are not valid or of sufficient import, we invite them to imagine what their sentiments would be if a similar project were 
proposed within a stone's throw of their own homes."

The points on which the writers sought "clarification" were:

- $\quad$ Numbers. "How many Indians will be involved? Will there be fifty, or will there be five thousand? The answer will affect the entire economic and social status of the Cascade Locks community," the letter stated. Industrial expansion would bring new taxable wealth and jobs but the Indians would bring neither, leaving the "entire burden" of additional schools, churches and recreational resources to present residents.

- In essence, why us? The letter writers said Indians had not fished in that area since Cascade Rapids was flooded by the Bonneville pool and the only fishing had been by anglers from the banks of the canal. Even before the dam, Indians "were never too enthusiastic" about the site and it was then no longer suitable to traditional Indian methods.

- Exclusive fishing rights for the Indians. The letter writers worried about excluding sports fishermen from the Celilo Canal and "inevitable conflicts" between Indians and sports fishers. "Have the Army Engineers given equal consideration to their [sportsmen's] rights as citizens?"

- Sanitation facilities. Would they be "Chic Sales" or modern lavatories? "What provisions have been made to keep the grounds clean and orderly? Or will this be the typical dog-ridden village such as existed for so many years at Celilo and other Indian fishing sites? Indian villages are usually picturesque affairs which are a delight to tourists, but living with one in the heart of a little community such as ours would present obvious problems."

- $\quad$ Fish drying. "Has consideration been given to the effect the operation of such facilities right in the heart of town would have on property values in and around Cascade Locks?"42

Lipscomb outlined the situation for his superior, the Division Engineer for the

North Pacific Division, with a letter dated April 24. He then asked for authority to abandon Herman Creek and reassign the government land at Cascade Locks as an in lieu site for the Indians. He sketched the objections from the Cascade Locks group, citing the April 13 meeting, not the April 22 letter, although the arguments were the 
same in both. The colonel said that before the delegation visited him, "a business man in Cascade Locks favoring the establishment of a replacement Indian fishing site" there called the Corps and indicated that the delegation "did not represent the majority opinion in Cascade Locks." He did not name the businessman. Lipscomb said, in his letter to the Division Engineer, that the extent of Indian use of the site would depend largely on the availability of fish from the Oregon Fish Commission, Fish and Wildlife Service and other sources. He added, in a line that takes on significance in a later controversy, "While the houses will no doubt be occupied permanently by the Indians, it is questionable whether the premises will be otherwise used by the Indians except for camping purposes during the Fall fishing season. It is doubtful if the Indians will ever have sufficient fish to dry to cause offensive odors for any distance."

\section{The Corps Says No}

Congress had ordered the eight acres proposed for the Indians turned over to the Port of Cascade Locks in 1940, Lipscomb said, on condition the port pay not less than 50 percent of its appraised value. The land and improvements were appraised in 1941 at $\$ 19,194$. "The money was never paid," Lipscomb said. "District's files indicated that the Port of Cascade Locks objected to provisions of the Act which limited the use of the land and improvements to municipal parks and docking purposes." He cited correspondence from May 1949 indicating the city and port of Cascade Locks "were no longer interested in purchasing the property from the government."

Lipscomb enclosed copies of letters from the Cascade Locks Citizens 
Committee and "various individuals," noting that each would be answered. A meeting with the Citizens Committee and representatives of the Bureau of Indian Affairs had been held on April 23 in the Corps' District Office, Lipscomb said, and certain agreements were reached. The citizens group would first try to reconcile its own internal disagreements and then submit to the BIA a proposal for regulations governing the use of the site. The proposal would be submitted to the Indians and a committee with representatives of all sides would work out differences. Lipscomb also suggested complying with a recommendation from the Warm Springs Tribes and the Umatilla Board of Trustees that an island across the canal and northwest of the locks be included in the site. If the Indians' fish drying were carried out on the 7.62 acre island it would further remove them from the residential area of Cascade Locks, he said. The site would provide the Indians more seclusion and, with the prevailing winds, "eliminate any possible objections ro offensive odors,"

Lipscomb also provided a report on the current status of the other sites listing again small progress. Improvements at Big White Salmon were to be completed before May 1. Construction of water and sanitary facilities and improvements of the access road were under way at Lone Pine. The Yakima Tribes were refusing to consider an alternate to Big Eddy until they saw appropriations bills related to The Dalles Dam. Skamania County and the Forest Service were building a road to the Wind River site, eliminating the need for an added piece of land originally included. Acquisition of part of Alternate Little White Salmon was still stalled pending assurance funds would be 
available for improvements. ${ }^{43}$

While Lipscomb was proceeding with the plan to use the Cascade Locks site, Nichols was going to Congress. On April 24 he wrote to Congressman Coon. Nichols enclosed the letters gathered by the local committee, which he said, "was chosen to represent the citizens of this community at a well attended public meeting." He said the committee had met with the Corps and a Mr. Toole and Mr. Barrett of the Bureau of Indian Affairs and "they decided to have a meeting within ten days with the Indians to see if we can work out the problems." He added, "It will be a difficult problem considering the advice the Indians are getting from some whites." The committee had suggested two alternate sites, both "removed from communities," Nichols said. To clinch his arguments, Nichols wrote:

We don't want a Celilo village here. A group of Indians would be welcome to live here and would be an asset to our community of they would abide by the same laws as do the rest of us and live as we do and not want a lot of extra rights.

We would like to call your attention to the fact that the Indians want exclusive fishing privileges to an area, the Cascade Canal, that never was an Indian fishing spot. It is man made and the Indians have never fished in it. ${ }^{44}$

What Nichols didn't know - or didn't care to know - was that the Cascade Locks site was described as an Indian fishery in the first full-scale report of the Indians' "usual and accustomed places." "... there also is a dip-net fishery on the Oregon side of the river, at which Indians are also accustomed to take fish," wrote George W. Gordon, a special Indian agent for the government, in 1889. "This fishery is on land condemned and appropriated by the government for the purpose of constructing the 'Cascade 
Locks'- now under construction." ${ }^{45}$

Coon wasted no time rushing to the aid of his constituents. Of course, both the Warm Springs and Umatilla reservations were within his district also, but he seems to have made up his mind before asking the Chief of Engineers, the top official of the Army Corps of Engineers, to investigate and advise him. "I can well understand the citizens of this town being unwilling to agree to this situation," Coon wrote on April 28. "It is a small community and would be unable to cope with the situation as outlined in the letter, and it appears that some other site, not located in the immediate vicinity of a community, would be more desirable to all concerned. ... I wish to protest the proposed transfer of this property to the Department of the Interior for use by the Indians. ${ }^{\circ 6}$ The Corps headquarters told the Division Engineer to draft an appropriate reply "together with your remarks and recommendations" as quickly as possible ${ }^{47}$, a standard reaction by the bureaucracy to a congressional inquiry. The same day, Brig. Gen. C.H. Chorpening, the Assistant Chief Engineer for Civil Works, responded to Coon, telling him that the matter had been referred to Col. Emerson C. Itschner, the Division Engineer, "for investigation and report."

Nichols of the Cascade Locks Citizens Committee got his reply before Itschner's office produced the draft of a response to Coon. Lipscomb, the District Engineer, answered Nichols' five questions one by one:

- The number of Indians who might exercise their fishing rights at Cascade Locks is "speculative." However, "it is safe to conclude that the number of Indians who fish there will be proportionately less than the number who fished there before construction of Bonneville Dam" because the fishing is poorer. 
- Reasons for selecting the site included its ownership by the government, safe access across the railroad right-of-way, availability of sanitary facilities, the site was one of the best remaining in the Bonneville pool and it was in an area where the Indians had treaty rights.

- The decision about exclusive use by the Indians would be made by the Department of the Interior. However, Lipscomb pointed out that the Corps had allowed sports fishermen to use the government property "as long as it did not interfere with the governmental purposes for which the land was acquired." The fishermen acquired no permanent right to fish there through using the property, he said, adding that the complainers could have insured permanent use of the land for their own purposes had they bought it in 1949 when it was available.

- Lipscomb appeared especially annoyed by the question about sanitary facilities. "The sanitary facilities for the site are located in the existing houses that have been used by Government employees for many years and which are believed to be similar to those in use elsewhere in the City of Cascade Locks," he wrote. Future construction would have to meet state and city codes, he said.

- He doubted that the Indians would have enough fish to dry to create offensive odors and noted that prevailing winds are not in the direction of business or residential sections of the town.

Lipscomb also "clarified" the objectors' repeated references to the site as being "in the heart of the town." "Actually the tract is effectively separated from the business district of the town by the Union Pacific Railroad tracks, a fence, and a screen of trees and brush," he wrote. "The only access across the tracks is an underpass under the railroad which also gives access to the Government land now used as a city park." The 7.6 acres on an island was 580 feet from the business district at the nearest point, Lipscomb noted. ${ }^{49}$

\section{Explaining To Congress}

The draft of the response to Coon, which was undated although probably written 
before the May 15 deadline set for Itschner's response, outlined the history of the lieu sites. It said a copy of Lipscomb's response to Nichols and the committee was enclosed to answer the questions raised to the Corps and to Coon. The draft noted the strong opposition by the Oregon Fish Commission to the Herman Creek site, the advantage of using property the government already owned and that little was left of the $\$ 50,000$ appropriation. "Telephone calls, newspaper articles and conversation with various persons, business men and residents indicate that Mr. Nichols and his associates do not voice the sentiments of all the citizens of Cascade Locks," the draft stated. "Some have expressed dissatisfaction with the protests filed against the use of a portion of the Cascade Locks property for the Indians." The draft also explained that neither site suggested by the Cascade Locks committee as alternatives was available, Bradford Island at Bonneville Dam because it was closed to the public except daylight hours for security reasons and the mouth of the Sandy River because it was outside the Bonneville pool. Other potential sites had been investigated and found either unavailable or unusable.

The draft also outlined the agreement over regulations for use of the site and said that no proposed rules had been submitted by the Cascade Locks groups. The draft stated that the site had been one of the Indians' ancient fishing places, which they abandoned only because of construction of the locks. Having refuted most of the committee's arguments, the draft continued, "I certainly agree with you that it would be highly undesirable to permit establishment of a large concentration of Indians living 
in temporary shanties on the outskirts of the town of Cascade Locks at the site under discussion. However, I would like to assure you that such a prospect exists only in Mr. Nichols' imagination and that of a very few of his associates." The draft said the site appeared to be the only alternative unless Congress modified the 1942 law to make some other settlement with the Indians and it noted the "very heavy expense" of the settlement for drowning Celilo Falls by The Dalles Dam. ${ }^{50}$ There was no further correspondence from Congressman Coon.

The final word in the dispute appeared then to belong to Lipscomb, the District Engineer. In a letter to W.W. Cameron of the Cascade Locks Citizens Committee, Lipscomb said he enclosed a copy of a letter addressed to him, dated May 14 "purporting to be a product of your committee, but it is noted the letter received in this office was signed only by Mr. R.H. Nichols." No copy of that letter appeared in the file but a copy of Lipscomb's response, also listed as an enclosure, did appear. In the letter to Cameron, Lipscomb said the Corps intended to consider the desires of the community before taking final action but "in view of the insulting tone of Mr. Nichols" letter," he asked that the committee appoint someone else to work with the Corps. Public interest would be best served if matters were considered "in a reasonable and unimpassioned manner," he said. ${ }^{51}$

In an attached copy of "Comments on letter dated May 14, 1953, from R.H. Nichols, Cascade Locks Citizens Committee, Lipscomb icily itemized his response:

"With respect to transients, it appears from verbal statements previously made by members of your committee that you now have more of a transient 
problem in the fishermen now using the land along the canal walls than you ever should have from the Indians."

There is no basis to a charge that "the Government desires segregation to settle difficulties" arising from conflicts in usage of the site.

Congress determines the use of government property, including the site in question.

The Corps is unaware of any residential property within 150 feet of the site.

The sanitary facilities issue appeared to particularly annoy Lipscomb. Once more defending the adequacy of those facilities, he added, "It should be noted also that the area leased to the city for park and recreational purposes contained a 'Chic Sale' latrine which was burned on May 22, 1953."

Regarding the eighth and ninth paragraphs of Nichols' letter, Lipscomb wrote, "Here the comments go beyond the factual dispute and reflect discredit on the intentions of the District Engineer personally in this matter. Notwithstanding the defamatory remarks therein contained, the files of this office clearly indicate that both the port and City of Cascade Locks were given and have refused an opportunity to purchase the subject premises for municiple [sic] purposes." $\mathrm{He}$ added that if some statements contained in a night letter [then a form of telegram] were misleading "the source thereof must be considered."

The entire site totals about 16 acres with 7.6 available to the Indians on the island formed by the canal. ${ }^{52}$

Despite Lipscomb's stout defense of Cascade Locks as a good site for the Indians, the Corps' District Office later asked permission to resume negotiations toward allowing the Port of Cascade Locks to acquire the site ${ }^{53}$ The site eventually became one of the in lieu sites, however. A set of rules proposed for the site was drawn up but there is no indication who wrote them or when and whether they ever were adopted. The proposed rules do make reference to "all Indians permanently residing on the site." The BIA would require formal resolutions approving the rules 
from the tribes and Celilo Fish Committee before turning the site over to the Indians. ${ }^{54}$ Also during May, apparently spurred by a claim or rumor of a claim for damage to the fishery as a result of Bonneville Dam, the Corps turned its attention to fish carcasses that state and federal agencies had been supplying to the Indians from hatcheries on the Columbia River tributaries. In a May 1 letter to Leo L. Laythe of the U.S. Fish and Wildlife Service in Portland, Lipscomb, the District Engineer, outlined the status of each in lieu site and included a comment, "While fish carcasses are now being furnished to the Indians by the United States Fish and Wildlife Service at Little White Salmon and Big White Salmon, there is no obligation on the part of the Corps of Engineers under the Act or the agreement with the Indians to provide them with fish at any of these sites, or otherwise." His reason for including the comment was unclear; it bore no relation to the remainder of the letter. ${ }^{55}$

Later, on May 29, Lipscomb wrote to the Division Engineer asking for copies of correspondence dealing with the fish carcasses furnished to the Indians. "As part of the settlement with the Indians for flooding of the fishery at the Bonneville Dam, the U.S. Fish and Wildlife Service are [sic] allowing the Indians, mostly from the Yakima Tribe, to take fish carcasses from the three Federal owned hatcheries in Washington adjacent to the Bonneville Reservoir," he wrote. "The concession amounts to a considerable item since they actually delivered to the Indians 300,000 pounds of salmon carcasses last year and a somewhat lesser amount the previous year." Lipscomb said donation of the carcasses (which were spawned fish that would simply 
have been thrown away) was part of arrangements made during negotiations for the in lieu fishing sites, "but our file is not clear on the details." He said three letters had a bearing on the subject but there was nothing more. Neither the Indian Service nor the Fish and Wildlife Service could find additional correspondence in their files, he said. ${ }^{56}$ In the first of those letters, dated December 8, 1941, Lt. Col. C.R. Moore, then the District Engineer, recommended that the Secretary of the Interior guarantee delivery of salmon carcasses to the Indians at the White Salmon, Little White Salmon and Spring Creek (Underwood) sites "so long as the government shall continue to take salmon for propagation purposes." This recommendation was in connection with a condemnation action for Northwestern Electric Co. property flooded by the Bonneville pool. A number of Indians had joined the suit seeking damages for loss of fishing access. Moore said his recommendation "will eliminate the possibility of the Indians again appearing in court" in connection with damages from Bonneville Dam. ${ }^{57}$ Moore's recommendation was sent to John W. Fisburne, special attorney in the U.S. Attorney's Office in Tacoma, Wash., on December 16 by Don B. Meldrum of the Corps of Engineers as part of a proposed settlement of the Northwestern Electric suit. ${ }^{58}$ On January 1, 1942, Robert P. Patterson, Under Secretary of War, told the Secretary of the Interior, then Harold L. Ickes, about the Corps proposal. ${ }^{59}$ It was a response to Patterson's letter that the Corps was seeking in vain in 1953.

On September 10, 1953, Percy M. Othus, special assistant to the District Engineer, responded to a request for comments on testimony in connection with a 
Yakima Tribe claim related to the "effect of Bonneville Dam on Salmon Population in the Columbia River." He called attention to "the matter of salmon carcasses being supplied to the Indians by the U.S. Fish and Wildlife Service, which we consider an important matter in connection with this law suit." The agency had supplied the Indians with about 250,000 pounds of salmon carcasses in 1951 and 300,000 pounds in 1952, Othus said. He cited the same three letters of December 8 and December 16, 1941, and January 1, 1942, to support his contention that the salmon were being furnished as consideration for damage to the fishery from the dam. Since that was the case, "the values should rightly be deducted from any compensation they might otherwise be entitled to," he said. Othus also called attention to recent testimony by Sen. Warren G. Magnuson, D-Wash., regarding the " 15 percent reduction in the fish run due to Bonneville Dam. ${ }^{.60}$

\section{Now The States}

June saw the states of Washington and Oregon raising objections to the sites and to Indian fishing in general. On June 16, Lipscomb told Robert J. Schoettler, Director of the Washington Department of Fisheries, he could not estimate the date the Corps would transfer the in lieu sites to the Department of the Interior. He said, however, consideration was being given to transferring the one or more sites on the Oregon side of the Columbia and the Big White Salmon site at Underwood, Wash., "within the next few months." Those sites "are now or will be completed at an early date," he said. Acquisition of the Little White Salmon site had been abandoned, he added. Lipscomb 
enclosed copies of various tribal and Celilo Fish Committee resolutions related to the sites, then said, "Inasmuch as the understanding or agreement with the Indians is principally oral, copies thereof are not available." ${ }^{, 61}$

Schoettler responded with a warning that Washington was considering closing all commercial fishing "at some or all of the sites acquired for the benefit of the Indians." The Indians have no special fishing rights at those sites or anywhere else in Washington, he said, and the state has a right to regulate and control fishing in the interest of conservation and will take enforcement actions against any violations by the Indians. He also said any fishing at the Big Eddy site, so close to The Dalles Dam, would violate state regulations and he was "most disturbed at the mere implication that the fish should not be afforded complete protection" there. As a hand written note on the file copy of the letter noted, the site was not turned over to the Indians. It had in fact been long since turned over to The Dalles Dam project. ${ }^{62}$

A few days later, the state of Oregon joined in the attack on Indian fishing. John C. Veatch, chairman of the Oregon Fish Commission, told Lipscomb in a June 30 letter that, while the treaties protected Indian fishing at their usual and accustomed places, "conditions are no longer such that such rights can be lawfully or practically projected to other locations." Increasing population and regional development meant that "no uncontrolled fisheries can be permitted to exist if the salmon runs are to be maintained at a valuable level," Veatch said. He devoted several paragraphs to denouncing the large amount of fish taken by the Indians "under the thin veil of 
subsistence fishing." He then said that all of the in lieu sites "have grave possibility of severe damage" to the fish runs. He protested the Herman Creek site, which had been abandoned. Cascade Locks, he said, "holds inherent fishing possibilities." Lone Pine "is by far the greatest threat to the survival of the runs" because of its nearness to The Dalles Dam fishway. Fishing there, he said, would be "contrary to Oregon law and policy" and "alien to conservation practices." He concluded:

We formally protest the granting of these sites to the tribes, for it is our belief that the major use to which they can be put is that of fishing, and the fishing is a threat to the continuance of the salmon runs.

Further, I would like to mention that the intention of the Washington Department of Fisheries and the Oregon Fish Commission is to close the area above Bonneville Dam to commercial fishing. ${ }^{63}$

It is no wonder then, considering that such policies had long been discussed, that Nora Woodward Evans of Hood River, one of the fishing Indians, wrote Lipscomb on June 30, "My family seems to think, as things stand, we would rather have a cash settlement for our rights. We are all settled in our own homes. With the public feelings as they are, we have all agreed on this. Perhaps this will be the time for us that promises won't be broken. ${ }^{, 4}$ Col. John A. Graf, the District Executive Officer, responded that "there is no provision for a cash settlement." That would require approval by the tribes and an amendment to the law. ${ }^{65}$

So the process limped on. Graf reported that on August 10 during a meeting in the Division Engineer's office it was agreed that the Corps would request transfer of the Big White Salmon and Lone Pine sites to the Department of the Interior, prepare 
an estimate of the work that could be done with the money remaining from the $\$ 50,000$ appropriated, prepare an estimate of the cost to complete the project, reopen negotiations with the Yakima Tribes over a substitute Big Eddy site and take no further action in regard to Cascade Locks. ${ }^{66}$

On September 29, Stanley, who had become chief of the Corps' district acquisition branch, reported little luck in finding alternate sites. The Washington Department of Fisheries objected to every known fishing site as an alternate to Big Eddy, he said, but there were several potential camping or fish drying sites if the Indians would accept those. Previously they had refused to accept anything but a fishing site. However, he added, because Big Eddy is within The Dalles Dam area and a cash settlement was being made for loss of The Dalles fishery, "I think that a little pressure on the Indians to abandon the Big Eddy site would be in order after the cash settlement is made with the Yakima Tribe." Stanley also suggested that "in view of the pressure that was put upon the various Indian tribes involved to approve the Cascade Locks site as an alternate for the Herman Creek site," the Corps should be sure any other site could be obtained and approved before asking the tribes to consider it. ${ }^{67}$

Graf issued a status report to the Division Engineer in a memo November 18, reporting that work had been completed on the Big White Salmon and Lone Pine sites. That work, did not, however, include living quarters and drying sheds "due to limited amount of funds available, which are required for acquisition of lands and construction of facilities originally provided for." Trial of condemnation action for the second 
parcel of Little White Salmon was still delayed pending assignment of a judge. The owner was willing to settle for $\$ 2,000$, "whereas our deposit was only $\$ 600$," Graf said. The S.P. \& S. Railway Company was contesting the taking of a portion of its right-of-way. The second portion of the Wind River site, which the Corps at one point said it had acquired, was still in litigation awaiting assignment of a judge. After another reconnaissance the Corps had picked two possible alternatives for Big Eddy and two for Herman Creek. ${ }^{68}$

Finally, on November 25, the Portland District of the Corps made a formal recommendation to the Division Engineer that the Big White Salmon site be transferred to the Department of the Interior. The 4.19-acre site had an estimated value of $\$ 1,500$ and the government had spent $\$ 5,878$ to make improvements, including one incinerator, two toilets, a domestic water supply well with hand pump and 2,600 yards of fill material. ${ }^{69}$ So 14 years after the government promised to replace the lost fishing sites, the Indians appeared to be on the verge of receiving the first one.

\section{In Reverse}

The Corps obtained appraisals of four potential sites to substitute for Big Eddy, lost to The Dalles Dam construction, and for Cascade Locks, the Herman Creek substitute that was being sold instead to the Port of Cascade Locks. On January 4, 1954, Col. T. H. Lipscomb, the District Engineer, asked the Division Engineer for authority to acquire two of the four new possible sites. "Since securing approval of the Indians for these sites is generally most difficult and time consuming," he wrote, "it is 
believed to be most practical to secure acquisition authority prior to any contact with the Indians. ${ }^{, 70}$ In response to a query from E. Morgan Pryse, the Area Director of the Bureau of Indian Affairs, Lipscomb explained that the land was going to the port in response to a 1940 act with which "representatives of this office were not familiar at the time of negotiations with the Celilo Fish Committee." earlier, Lipscomb told the Cascade Locks Citizens Committee that both city and port had rejected the land under provisions of the 1940 act and he was therefore free to turn it into an Indian fishing site. There is nothing in Corps or BIA files to explain this reversal. However, it will be recalled that Congressman Coon came to the defense of his Cascade Locks constituents and he may have persuaded the highest levels of the Corps that a one-time rejection of an offer did not mean a permanent rejection.

Apparently no one told the Indians. On February 8, Nora Woodward Evans, the Hood River woman who a few months earlier had been ready to sell her fishing rights for cash, said she had been under the impression the Indians could dip net at Cascade Locks that spring. "Now we understand you have sold that site," she wrote in a letter to the District Engineer. "It seems to me we Indians are losing our beloved Columbia River ... Would you please let us know just what you have decided about this site.?"72 Lipscomb responded on February 18, telling Evans essentially what he had told Pryse, that the 1940 law tied his hands so far as the Cascade Locks property was concerned. He closed, "... please be assured we fully appreciate your problems.",73

By that time, Lipscomb was obviously tired of the lieu site issue. On February 
12 he recommended that the Big White Salmon site be transferred to the Department of the Interior, stating that the action could be taken without prejudicing the government's position in a claim by the Yakima Indians for the loss of fish caused by The Dalles Dam. He suggested that a similar transfer of the Lone Pine site could be made because the Warm Springs Tribes had agreed to drop their claim for damages to fishing sites in the Bonneville pool once they received the $\$ 4,047,800$ settlement of The Dalles Dam damages. "It is the desire of this office to fulfill its obligation ... at the earliest possible time," Lipscomb wrote. "The matter has been pending now a considerable length of time, in large measure due to the very difficult problem of securing the approval of the Indian Tribes and others involved of sites selected or alternate sites to be selected." ${ }^{74}$

The recommendation was still pending June 29, when John A. Graf, the acting District Engineer, wrote to John Whis [sic], chairman of the Celilo Fish Committee, asking that "there be no alterations or additions to the existing facilities" until the transfer to the Interior Department was completed. ${ }^{75}$ By year's end, with the transfer still pending, the Yakima Tribes called in their attorney. Paul M. Niebell, representing the tribes, asked the new District Engineer, Col. J.U. Moorhead, to confirm in writing a statement Moorhead had made at a November 29 meeting concerning the transfers. According to Niebell, Moorhead had stated that the Justice Department ordered him not to transfer the sites to the Interior Department until "certain unrelated claims cases" before the Indian Claims Commission were dismissed. The in lieu sites were to 
replace sites inundated by the Bonneville Dam pool and were not related to the Warm Springs, Yakima and Umatilla claims before the commission, Niebell said. ${ }^{76}$ Moorhead told him to take it up with the Justice Department. Despite Niebell's contention that the claims were unrelated to the sites, Moorhead said the claim contained language stating that Bonneville Dam inundated and destroyed Yakima fishing sites, greatly reducing the tribes' property rights to the fish. ${ }^{77}$

Conflicts arose over the sites from two other quarters, sportsmen and county government. On August 11, Graf, then again Assistant District Engineer, wrote to Fred W. Mintzer, secretary of the Washington State Sportsmen's Council, to answer some questions raised by the council. Negotiations for the loss of the fishery from The Dalles Dam do not include in lieu fishing sites, Graf wrote, and the Indians will not be permitted to fish "in the immediate vicinity of the dam." The Lone Pine and Big White Salmon were being used temporarily by the Indians pending site transfers to the Interior Department. "This office considers that the use of these sites by the Indians will not seriously affect the fish runs in the Columbia River, and in fact, it is not known whether they will have any substantial use by the Indians," Graf wrote. "Certainly their use will in no way compare with the present use of the Celilo fishery or the previous fisheries flooded out by Bonneville Dam." Graf also noted that the Washington Department of Fisheries and Oregon Fish Commission objected to Indian fishing sites of any kind along the Columbia River, but the Corps "is without authority to consider their objections" under the law requiring establishment of the in lieu 
sites. $^{78}$

On September 15, Wasco County District Attorney Donald E. Heisler asked John Whiz [sic], chairman of the Celilo Fish Committee, to help arrange a conference over complaints about Indian buildings on the Lone Pine site. In the politely worded letter, Heisler suggested holding the meeting in late September or early October, after fishing season. "It appears that some conflict has developed between Wasco County on the one hand and certain Indians who are constructing buildings of one type or another on a portion" of the site, Heisler wrote. He suggested that delegates from the Yakima, Warm Springs, Umatilla and Mid-Columbia Indians attend. ${ }^{79}$

At this point the documentation thins out and little is available except a summary in a briefing book prepared for Congress in 1988 by the Columbia River Inter-Tribal Fish Commission.

The Yakima claim over The Dalles Dam was settled early in 1955 and on March 2, the Corps notified J.W. Elliott, superintendent of the Warm Springs Agency that "appropriate action will be taken by this office to effect immediate transfer" as soon as it received official word of the settlement. The transfer presumably referred to the two in lieu fishing sites. ${ }^{80}$ The Corps did not actually transfer the sites until 1956 and the Bureau of Indian Affairs did not accept the transfer until $1957 .^{81}$ The Corps' improvements on the 4.19 acres at Big White Salmon included an incinerator, toilets, well with hand pump and 2,800 yards of fill. On the nine acres at Lone Pine, the Corps had built an incinerator, toilets and domestic water supply well. ${ }^{82}$ 
Congress increased the amount of money for the in lieu sites to $\$ 185,000$ June 8 , 1955. The Oregon Fish Commission promptly protested any added funds for the sites. "They say the in lieu site program is illegal and unwise."

Once it had the two sites, the BIA directed the superintendent of the agencies to make arrangements for the tribes to assume responsibility for maintenance out of tribal funds. The tribes had rejected such a suggestion in 1954 but had indicated they would consider it after the sites were developed.

In 1957, the tribes were restricted to subsistence fishing because of the "tremendous fish loss after completion of The Dalles Dam." There was confusion among the tribes about which tribe could use each site. And the BIA drew up proposed regulations for site use that prohibited construction of permanent buildings.

"Apparently nobody assumed responsibility for the sites" during 1958 and their condition deteriorated, according to the BIA summary. In March 1959 the tribal fish committees met with BIA and drew up an agreement for managing the sites. Under the agreement, the Yakima Tribes would maintain and police Big White Salmon and the Umatilla and Warm Springs Tribes would work out a joint arrangement to maintain and police Lone Pine. The committee accused the Corps of not living up to the 1939 and later agreements, complaining that the improvements were inadequate. By September the Umatilla and Warm Springs Tribes had worked out their agreement and enacted resolutions accepting responsibility for Lone Pine. Yakima had not acted.

At that time, the Corps of Engineers recommended that the Chief of Engineers 
tell Congress that the Corps was unable to finish acquiring the in lieu sites ordered in the 1945 legislation. Soon, however, the agreements for Little White Salmon and Wind River were completed ${ }^{84}$ 


\section{NOTES}

1. House Document 531, Appendix Q, Volume VII, May 17, 1950, pp 2949-2953.

2. Edward G. Swindell, Jr., letter to James Jim, Apr. 13, 1951, Box 114, Yakima Indian Agency, 002-036.1, Bureau of Indian Affairs, Record Group 75, National Archives - Pacific Northwest Region, Seattle.

3. Report of meeting, Apr. 16, 1951, Toppenish, Wash., Ibid.

4. B.L. Price to Area Director, Office of Indian Affairs, Box 11, Field Agent, The Dalles, Ore., 1939-53, 155 K-S, Bureau of Indian Affairs, Record Group 75, National Archives - Pacific Northwest Region, Seattle.

5. Critchfield, teletype message to E. Morgan Pryse, May 28, 1951, Ibid.

6. E. Morgan Pryse, teletype to Commissioner of Indian Affairs, May 29, 1951, Ibid.

7. Pryse, letter to Commissioner of Indian Affairs, May 29, 1951, Ibid.

8. Pryse, letter to Col. D.S. Burns, May 29, 1951, Ibid.

9. Pryse, letter to Perry Skarra, Richard D. Butts and J.W. Elliott, May 31, 1951, Ibid.

10. D.S. Myer, letter to Chairman, Yakima Tribal Council, June 8, 1951, Box 114, Yakima Agency, 002-036.1, BIA, RG 75, NA-Seattle.

11. Pryse, letter to Skarra, Butts and Elliott, June 19, 1951, Ibid.

12. Public Law 14, Chapter 19, 79th Congress.

13. Minutes and resolution, Celilo Fish Committee meeting, July 20, 1951, Corps of Engineers, Portland District files, and Box 11, Field Agent, 155 K-S, BIA, RG 75, NA-Seattle.

14. Resolution, July 24, 1951, Perry E. Skarra, letter to B.L. Price, July 26, 1951, Box 114, Yakima Agency, 002-036.1, BIA, RG 75, NA-Seattle.

15. Perry E. Skarra, letter to E. Morgan Pryse, Aug. 3, 1951, Ibid.

16. Handwritten document, undated, in Corps of Engineers, Portland District files. 
17. A.D. Stanley, notes on meeting with representatives of Yakima Tribal Council and Fish Committee, Dec. 7, 1951, Ibid.

18. James W. Sloat, memo to Division Engineer, Feb. 7, 1952 "Replacement of Indian Fishing Sites, Bonneville Dam and Reservoir Project," Ibid.

19. Richard D. Butts, letter to District Engineer, Corps of Engineers, Apr. 9, 1952, Ibid.

20. Donald L. Parman, "Inconstant Advocacy: The Erosion of Indian Fishing Rights in the Pacific Northwest, 1933-1956," in The American Indian Past and Present, 4th ed., ed. Roger L. Nichols (New York: McGraw Inc., 1992) 246, 249.

21. Uncommon Controversy: Fishing Rights of the Muckleshoot, Puyallup and Nisqually Indians, a Report Prepared for the American Friends Service Committee (Seattle: University of Washington Press, 1970), 65.

22. Theodore W. Taylor, The Bureau of Indian Affairs (Boulder, Colo.: Westview Press, 1984), 24.

23. Sloat memo, Feb. 10, 1951, Corps of Engineers, Portland District files.

24. Sloat, letter to E. Morgan Pryse, Feb. 8, 1952, Ibid.

25. Pryse, letter to District Engineer, Corps of Engineers, Feb. 13, 1952, Ibid.

26. Wilson Charley, letter to A.D. Stanley, Mar. 12, 1952, Corps of Engineers, Portland District files; also Box 114, Yakima Agency, 002-036.1, BIA, RG 75, NASeattle.

27. T.H. Lipscomb, report to Division Engineer, Mar. 21, 1952, Corps of Engineers, Portland District files.

28. Brig. Gen. Emerson C. Itschner replaced Brig. Gen. Orville E. Walsh as division engineer in April 1, 1952.

29. Sloat, letter to Division Engineer, Mar. 25, 1952, Corps of Engineers, Portland District files.

30. Resolution, Umatilla Tribes, Ibid.

31. Sloat, letter to Division Engineer, Sept. 11, Ibid. 
32. Skarra, letter to District Engineer, Aug. 4, 1952, Ibid.

33. Sloat, letter to Perry E. Skarra, Sept. 18, 1952, Ibid.

34. Butts, letter to District Engineer, Apr. 9, 1952, Ibid.

35. Sloat, letter to Richard D. Butts, Apr. 23, 1952, Ibid.

36. Resolution, Warm Springs Tribal Council, meeting of Sept. 8-10, 1952, Ibid.

37. Sloat, letter to Division Engineer, Sept. 16, 1952, Ibid.

38. Jasper W. Elliott, letter to Bryon L. Price, Oct. 13, 1952, Ibid.

39. Report, Jan. 26, 1953, Ibid..

40. Lipscomb, letter to W.W. Cameron, May 26, 1953, Ibid.

41. Lipscomb, letter to Division Engineer, Apr. 24, 1953, Ibid.

42. Russel H. Nichols and others, letter to T.H. Lipscomb, Apr. 22, 1953, Ibid.

43. Lipscomb, letter to Division Engineer, Apr. 24, 1953, Ibid.

44. Nichols, letter to Sam Coon, Apr. 24, 1953, Ibid.

45. George W. Gordon, "Report upon the subject of the fishing privileges etc. guaranteed by treaties to Indians in the Northwest with recommendations in regard thereto," Jan. 19, 1889, Ibid.

46. Sam Coon, letter to Chief of Engineers, Apr. 24, 1953, Ibid.

47. William Whipple, letter to Division Engineer, May 4, 1953, Ibid.

48. C.H. Chorpening, letter to Representative Sam Coon, May 4, 1953, Ibid.

49. Lipscomb, letter to Cascade Locks Citizens Committee, May 11, 1953, Ibid.

50. Unsigned draft of letter to Rep. Sam Coon, undated, Ibid.

51. Lipscomb, letter to W.W. Cameron, May 26, 1953, Ibid. 
52. Unsigned and undated "Comments on letter dated May 14, 1953, from R.H.

Nichols, Cascade Locks Citizens Committee," presumed from accompanying letter to have been written by T.H. Lipscomb, Ibid.

53. John A. Graf, memo to Division Engineer, Nov. 18, 1953, Ibid.

54. Undated list of rules, Ibid.

55. Lipscomb, letter to Leo L. Laythe, May 1, 1953, Ibid.

56. Lipscomb, letter to the Division Engineer, May 29, 1953, Ibid.

57. C.R. Moore, letter to Division Engineer, Dec. 8, 1941, Ibid.

58. Don B. Meldrum, letter to John W. Fishburne, Dec. 16, 1941, Ibid.

59. Robert P. Patterson, letter to Secretary of the Interior, Jan. 1, 1942, Ibid.

60. Percy M. Othus, memo to W.M. MacGibbon, Sept. 10, 1953, Ibid.

61. Lipscomb, letter to Robert J. Schoettler, June 16, 1953, Ibid.

62. Robert J. Schoettler, letter to T.H. Lipscomb, June 24, 1953, Ibid.

63. John C. Veatch, letter to T.H. Lipscomb, June 30, 1953, Ibid.

64. Nora Woodward Evans, letter to Colonel Lipscomb, June 30, 1953, Ibid.

Punctuation altered for readability.

65. John A. Graf, letter to Nora Woodward Evans, July 21, 1953, Ibid.

66. Graf, letter to Division Engineer, Aug. 11, 1953, Ibid.

67. Stanley, memo to Chief, Real Estate Division, Sept. 29, 1953, "Reconnaissance on Alternate Fishing Sites," Ibid.

68. Graf, memo to Division Engineer, Nov. 18, 1953, Ibid.

69. Graf, memo to Division Engineer, Nov. 25, 1953, Ibid.

70. Lipscomb, letter to Division Engineer, Jan. 4, 1954, Ibid. 
71. Lipscomb, letter to E. Morgan Pryse, Jan. 15, 1954, Ibid.

72. Evans, letter to District Engineer, Feb. 8, 1954, Ibid.

73. Lipscomb, letter to Nora Woodward Evans, Feb. 18, 1954, Ibid.

74. Lipscomb, memo to the Division Engineer, Feb. 18, 1954, Ibid.

75. Graf, letter to John E. Whis, June 29, 1954, Ibid.

76. Paul M. Niebell, letter to J.U. Moorhead, Dec. 2, 1954, Ibid.

77. J.U. Moorhead, letter to Paul M. Niebell, Dec. 7, 1954, Ibid.

78. Graf, letter to Fred M. Mintzer, Aug. 11, 1954, Ibid.

79. Donald E. Heisler, letter to John Whiz, Sept. 15, 1954, Ibid.

80. Merle E. Lietzke, letter to J.W. Elliott, Mar. 2, 1955, Ibid.

81. Les McConnell, "In-Lieu Site Historical Summary," in Briefing Book on Indian In-Lieu Fishing Sites and Fisheries Law Enforcement on The Columbia River between Bonneville and McNary Dams (Portland: Columbia River Inter-Tribal Fish Commission, 1988), 12.

82. Wilbur M. Brucker, Secretary of the Army, letter to the Secretary of the Interior, Sept. 6, 1956, Corps of Engineers, Portland District files.

83. Unsigned notes, Ibid.

84. McConnell, Historical Summary, 13. 


\section{CHAPTER V: THE SIXTIES - STATUS QUO}

\section{Changing Focus}

During the 1960 s the government's attention appears to have turned from acquiring additional sites and building the promised facilities to conditions on the sites it had obtained. At the same time, the states of Oregon and Washington accelerated their arrests of Indians, both on Puget Sound and along the Columbia River, in efforts to make Indians conform to state rules that the Indians said did not apply to them. The increasingly bitter battle was carried into the civil as well as the criminal courts, but it was the end of the decade before the Indians won a clear victory.' At the opening of the decade, 20 years had gone by since the government agreed to acquire 400 acres of fishing sites to replace the 37 flooded locations. It had acquired four sites, totaling just under 40 acres, and had built the fish drying sheds, water and sanitary facilities on only two. No effort was made to replace the Indian homes destroyed on the flooded sites.

In September of 1960, staff members from the Portland Area office of the Bureau of Indian Affairs visited the four sites it had accepted on behalf of the Indians. Their report indicated the sites were in fair condition - except that six families were living in the drying sheds at Lone Pine. ${ }^{2}$

Early that same year, the tribes began urging the Corps of Engineers to acquire the eight plus acres of the Cascade Locks site as it was originally proposed. In late April commissioners of the Port of Cascade Locks voted 3-2 to permit the Indians to fish on the north side of Cascade Locks - the 1.6-acre piece of the property - but only if 
the non-Indian community approved. The Corps agreed to look at the site to see if the Indians could use it effectively as a fishing site despite the fact that access would be only by boat, that there would be no sanitation facilities or place to camp and that there were several hazards. (There would be no action for two more years. ${ }^{3}$ )

The BIA took another look at the four sites in late October, starting a series of bitter recriminations. The BIA made its report in a series of pictures of the sites, sent the photos to the tribes and asked that the tribes enforce the regulations for use of the sites. At a later meeting attended by representatives of the BIA, the Celilo Fish Committee, the Corps and the U.S. Public Health Service, the tribes bitterly accused the Corps of not fulfilling its obligations. Among their complaints about the sites were: health hazards, impure water systems, lack of sanitation, improperly constructed sheds, failure to remove old buildings, failure to clean up trash and failure to improve access roads. The Yakima Nation refused to accept responsibility for the sites on the Washington side of the river because of the substandard conditions. The tribe suggested that title to the sites be given to the tribes and they would then assume responsibility for them.

An agreement was reached that the Public Health Service would inspect the sites for sanitary conditions and the tribes would furnish money for cleanup and garbage disposal through contracts administered by the BIA. The Indians also asked that the Corps spend the $\$ 75,900$ remaining from the 1955 appropriation for the sites to make the improvements rather than turning the money back to the Treasury. 
Another conference was held November 22 to discuss sanitary and other problems at the sites. The Yakima, Warm Springs and Umatilla Tribes all were represented along with the Indian Health Service, BIA and the Corps. The chairman of the Yakima Tribal Council, identified only as Mr. Saluskin, presided. ${ }^{4}$ Again the Yakima delegation charged that the Corps had not fulfilled its responsibility to provide six sites and the facilities agreed to in the August 9, 1939, resolution. The meeting apparently was heated with charges and counter charges. The Yakimas had their attorney, James Hovis, present and he outlined the tribe's position: The tribe would not accept the sites until they were brought up to standards; if the tribe accepted jurisdiction it wanted title to the land.

The Yakimas also complained that the BIA was asking the tribes to make and enforce rules, threatening to take away the sites if they did not meet the agency's standards. The tribes cited a letter from the BIA urging the tribes to adopt and enforce regulations. In it, the agency quoted a statement by the Secretary of the Interior that, if the sites were not properly used, they would be withdrawn and disposed of. ${ }^{5}$

Little happened in regard to the sites during the following year. In related activity, the tribes reached agreement with the states of Washington and Oregon on general fishing regulations, including a ban on use of gillnets above Bonneville Dam. That limited the tribes, but not non-Indian fishermen, who fished below the dam. ${ }^{6}$ Only the Umatilla Tribe is recorded as ratifying the agreement. ${ }^{7}$ In April, the Corps of 
Engineers reported it still had $\$ 75,327.62$ remaining of the $1955 \$ 185,000$ appropriation. $^{8}$

\section{More Site Searching}

The Umatilla Tribes' fish committee outlined the events of the year related to the in lieu sites in a report dated December 27, 1961. Indicating the continued importance of the issue to the tribes, nearly the entire report was devoted to acquisition of sites. The document also demonstrates the frustration and discouragement the tribes felt as government agents agreed to do things, then found reasons they couldn't carry out their promises.

The report began with a meeting of the three tribes with representatives of the Corps early in the year, at which the Yakimas announced they had given up finding a site to replace the Big Eddy site, which had been removed from Indian use for construction of The Dalles Dam. In addition, "after some discussion," the Yakima delegates agreed to let the Oregon tribes acquire sites in addition to Lone Pine before the Yakimas asked for improvements on the Washington shore sites.

Merle Lietzke of the Corps asked the Oregon tribal delegates which additional sites they wanted. "Reply was it would be hard to say because any Lieu sites the Oregon Indians asked for the request was always turned down, was not available or could not be bought because of price or was owned by some Oregon State organization," the Umatilla committee report said. Lietzke asked for another meeting to look at sites. The Oregon tribes told him again "we did not want camp sites, only 
fishing sites," the report stated. "Because a camp site would be no good to us if we did not have a place to catch salmon, besides a camp site would be an expense to the Tribes for up keep and for sanitation facilities." Percy A. Brigham, a committee member, suggested man made sites, but Lietzke rejected that idea.

The two tribes and the Corps representatives later looked at the old Rowena Ferry landing, a site below Hood River and a location one fourth mile below the old Cascade Locks. The Warm Springs delegates looked at a site near the Herman Creek hatchery but the Umatilla delegates didn't bother “because the Army Engineers had already told us it was unavailable." Lietzke said there was an old building and room for camping at the ferry site. The Hood River site, he said, "was quite expensive," would require construction of an access road and would need Union Pacific Railroad agreement for a crossing. As for the Cascade Locks site, "It looked alright [sic] to the ones that seen it, as far as anyone knows it is not known if it would be a good fishing place. It looked good that day because the high water caused a good back eddy," the report stated. ${ }^{9}$

The Warm Springs and Umatilla Tribes agreed informally early in 1962 that the Corps should acquire the Cascade Locks sites, 1.6 acres, and defer improvements to the other sites. The Umatilla Board approved "immediately" and the Warm Springs Tribal Council approved on March 26. The Yakima Tribe did not approve it until June 12. ${ }^{10}$ Meanwhile, on January 9, the Umatilla Board of Trustees authorized Percy Brigham to request use of the Cascade Locks site from the Port of Cascade Locks "if 
request is necessary for tribal use." "11 The Corps began condemnation proceedings to acquire the new site near Cascade Locks, which became known as Lower Cascade Locks.

There was another look at the Lone Pine site and conditions there were labeled "less than satisfactory with several families living in drying sheds." At a September meeting of the Corps and BIA, George Dysart, assistant regional solicitor for the Department of the Interior, told the committee the sites were federal property and the government could prescribe regulations for their use. ${ }^{12}$

The next year, 1963, saw more progress and less dissension:

1. The Department of the Interior Solicitor, identified only as U. Plummer, issued an opinion that the in lieu sites "were to be used in common with other citizens." ${ }^{13}$ [The treaties stated that the Indian retained the right to fish off their reservations "in common with citizens of the territory."]

2. The Umatilla fish committee also reported to the tribes' Board of Trustees on a potential site below Bonneville Dam between Moffett Creek and McCord Creek. The board authorized the fish committee to consult the tribal attorney "and report on what action needs to be done or could be taken to acquire the site." 14 The only further mention of that site came in minutes of the board for May 28, 1963, in which the fish committee reported it had contacted the area office of BIA about the site. ${ }^{15}$

3. The Corps acquired the Cascade Locks site and completed construction by December. ${ }^{16}$

4. The Corps still had $\$ 40,873$ left in the site fund and agreed to spend it improving the existing sites. ${ }^{17}$

\section{Sanitation Problems}

Apparently nothing was done however, until 1965 when action was prompted by health officers' inspection of the Lone Pine site in 1964. They found conditions "very 
bad" and recommended that the site not be used for either overnight camping or permanent habitation. The health officials (presumably from the Oregon State Health Department, although the briefing book does not identify them) sought action from the BIA, which completed a sanitary survey of all the sites in December 1964.

Early in 1965 the Corps estimated the cost of improving sanitary facilities at the four sites at $\$ 40,000$, almost exactly the amount it had remaining in 1963 from the appropriation for the sites. The remainder of the year appears to have been spent in wrangling over the sanitary conditions on the sites and who was responsible for improving them. The Wasco County District Attorney telephoned the regional solicitor for the Department of the Interior after the Wasco County Health Officer made further complaints about Lone Pine. The Clark-Skamania District Department of Health in Washington state also complained about the sites in that state. The Area Director of the BIA reminded the Commissioner of Indian Affairs that he had asked for authority to issue regulations governing use of the sites June 12, 1964, but had not yet received a reply. Responding to Wasco County, Dysart, the assistant regional solicitor, said he hoped regulations would be issued soon and, once they were issued, the federal government would need state help in enforcing them.

The Corps of Engineers Portland District obtained authority from higher headquarters to spend the remaining money to improve sanitation conditions, implying that authority was needed although there had been no previous reference to restrictions on spending the rest of the appropriation on the sites. The Corps said, however, it 
would make the improvements only on two conditions: That it have no responsibility to acquire additional sites, and that, if the work cost more than the amount estimated, the BIA must supply the rest of the money. ${ }^{18}$

In 1966, all three tribes approved spending the remaining money to improve sanitation at the already-acquired sites and agreed to give up purchase of a sixth site to replace Big Eddy. That left the Indians with 41.53 acres in five sites - Big White Salmon, 4.19 acres; Little White Salmon, 3.14 acres, and Wind River, 23.6 acres, in Washington and Lone Pine, 9 acres, and Cascade Locks, 1.6 acres, in Oregon. Despite the agreement, no work was done that year except another Public Health Service sanitary inspection of the sites in February. The service's officers found that all except Big White Salmon had deteriorated since November 1964. The Secretary of the Interior proposed rules for use of the sites but the briefing book does not detail them. ${ }^{19}$

Finally, in 1967, the BIA obtained a contract with Cascade Locks port personnel to maintain the Cascade Locks site. BIA also arranged regular garbage pickup at Lone Pine and Big and Little White Salmon. It could find no one to contract for pickup at Wind River but the site was little used and there was "no particular garbage problem." The Corps had not built a water supply for Lone Pine because a hook-up to the private water system in the area would have cost $\$ 20,000$. BIA arranged to remove car bodies and other debris from Lone Pine. ${ }^{20}$

\section{New Controversy}


The same year, 1968, the BIA amended its regulations for in lieu site use, touching off another controversy that worked its way eventually to a federal appeals court and Congress and resulted 20 years later in a new legislative directive to provide more fishing sites for the Indians. The rules, effective in mid-February 1968, barred any dwellings or structures other than camping facilities, which were defined as tents, tepees, campers and mobile trailers. The rule required that those must be removed from the sites whenever the owners were not catching, drying or processing fish. It called for removal or demolition of any structure built in violation of the rule. As the earlier proposed rules had done, the new regulations included provisions that the sites must conform to state and local laws on health, sanitation and safety. The initial version of the rules had not completely precluded year-around occupancy of the sites.

The new rule eliminating permanent residency drew strong opposition from Indians who lived along the river. Some sought help from members of the Northwest congressional delegation. A survey in May 1969 found 20 Indian-owned dwellings on the sites. The Indians argued that they could legally keep a dip net in the river or fish for sturgeon all year and therefore could legally live at the sites all year. Some of the Indians reminded the government they had been living at the sites flooded by the Bonneville Dam pool and that originally the Corps had promised to replace those homes. While they were complaining about that part of the government promise going unfulfilled, they also reminded the Corps they needed permanent drying sheds because drying salmon was a time consuming process. The corrugated metal sheds the Corps 
had built were not suitable for drying fish - the metal generated too much heat and burned the fish. Apparently, the Corps had not consulted Indians before deciding what type of drying sheds to build.

Through the spring and summer, the tribes, the Indians who lived along the river, the BIA and others tried to find a solution to the impasse over permanent housing. In October, Dysart, the government lawyer, responded to a formal request from the BIA with an opinion stating that the housing ban was legal. He said the treaties limited the Indians' off-reservation rights to taking fish and erecting temporary buildings for curing them. He said the Secretary of the Interior could allow permanent homes on the sites but was not required to. ${ }^{21}$

There is nothing in the briefing book and no correspondence available at this point to determine why the BIA decided to ban permanent dwellings on the sites. But the order came only months after the Sohappys and others filed their direct challenge to state authority, the case known as Sohappy v. Oregon. In 1969, U.S. District Judge Robert C. Belloni ruled that the Indians were entitled to a share of all the fish destined for the tribes' usual and accustomed fishing places. On the basis of that case, which became U.S. v. Oregon, the federal court still maintains final authority over management of fisheries on the Columbia River. The case, in which Dysart represented the Indians, was the forerunner of the famous 1974 Boldt decision in U.S. District Court in Washington, which held that the fair share for the Indians was 50 percent. During this period, non-Indians were blaming Indians for dwindling fish runs 
and the racism so evident in the earlier Cascade Locks and Lone Pine disputes was unabated. It is likely, then, that the BIA came under pressure from non-Indians in the Northwest and members of the congressional delegation to put as many limits as possible on the Indians. In addition, the termination policy under which the Eisenhower Administration ended federal recognition of dozens of tribes in the 1950s was not officially reversed until 1970 under President Richard Nixon. ${ }^{22}$ Certainly there were many non-Indians who hoped all the tribes would be terminated, particularly those with fishing rights on the Columbia. Termination was a threat to the BIA's existence - no recognized tribes, no need for BIA - and the bureaucrats who managed the agency could have hoped to diminish public antipathy towards the Indians by making it impossible for Indians to create villages outside the established reservations. 


\section{NOTES}

1. Uncommon Controversy: Fishing Rights of The Muckleshoot, Puyallup ans Nisqually Indians, a Report Prepared for The American Friends Service Committee (Seattle: University of Washington Press, 1970), 108, 111, 201

2. Les McConnell, "In-Lieu Site Historical Summary," in Briefing Book on Indian InLieu Fishing Sites and Fisheries Law Enforcement on The Columbia River between Bonneville and McNary Dams (Portland: Columbia River Inter-Tribal Fish Commission, 1988), 13.

3. Ibid., 13-14.

4. This probably was Alex Saluskin, identified in other papers as a committee member, but there were - and are - a number of Saluskins at Yakima.

5. McConnell, Historical Summary, 14-15.

6. Agreement sent with letters to tribal attorneys, Apr. 28, 1961, Box 1571, Portland Area Office, Tribal Council Minutes, 1950-65, Bureau of Indian Affairs, Record Group 75, National Archives - Pacific Northwest Region, Seattle.

7. Resolution, Umatilla Board of Trustees, June 13, 1961, Ibid.

8. McConnell, Historical Summary, 15.

9. Umatilla tribal fish committee report, Dec. 27, 1961, Box 1571, Tribal Council Minutes, BIA, RG 75, NA-Seattle.

10. McConnell, Historical Summary, 15.

11. Minutes, Umatilla Board of Trustees, Jan. 9, 1962, Box 1571, Tribal Council Minutes, BIA, RG 75, NA-Seattle.

12. McConnell, Historical Summary, 15.

13. Umatilla Board of Trustees minutes, Mar. 12, 1963, Box 1571, Tribal Council Minutes, BIA, RG 75, NA-Seattle.

14. Umatilla Board of Trustees minutes, Apr. 23, 1963, Ibid. 
15. Minutes, Umatilla Board of Trustees, May 28, 1963, Ibid.

16. McConnell, Historical Summary, 15.

17. Ibid.

18. McConnell, Historical Summary, 16-17.

19. Ibid., 17

20. Ibid., 17

21. Ibid., $17-19$

22. Gordon B. Dodds, The American Northwest (Arlington Heights, Ill.: Forum Press, 1986), 281 


\section{CHAPTER VI: THE SEVENTIES - MORE MONEY, NO ACTION}

\section{Call For Help}

A group of the river Indians, who had organized under the name Treaty Indians of the Columbia Inc., went to the United Nations in 1971 seeking help in resolving the entire dispute over Indian fishing rights, including the in lieu sites. ${ }^{1}$ Nothing came of it, but the effort served to call public attention outside the Northwest to the growing battle over fish. During the 1970s, pressures on the in lieu sites grew as fish runs began to rebound. In addition, non-Indian use of the river rose, increasing competition for access sites. ${ }^{2}$

While the controversy over both fishing and permanent living quarters on the sites continued, the Corps of Engineers created another complication with some help from the Bonneville Power Administration. BPA is the federal agency created to market the electrical power produced by the federal dams on the Columbia River and its tributaries. About 1970, BPA extended its operations with a proposal that came to be known as the Hydro-Thermal Power Program. Under that plan, part of the Northwest's increasing power needs would be supplied by building coal-fired or nuclear plants that would supplement the hydro-power from the dams that then supplied nearly all the region's electricity. It is cheaper to increase the flow of water through generators in a dam - and therefore the amount of electricity produced - than it is to start up and shut off a thermal plant. Therefore, the dams would be used to create the extra power needed during periods of highest usage, such as early evening when 
most families are cooking dinner. This use of the dams is known as "peaking." Peaking requires putting changing amounts of water through the dam generators, causing the level of the impounded water behind the dams to fluctuate. Bonneville, as the dam farthest downstream, would be used to level off the fluctuations to prevent interfering with communities, industries and river uses on the lower river. The Corps, which operates the dams, decided that efficient use of Bonneville Dam to control those fluctuations would require raising the maximum level of the Bonneville pool by three feet, to 77 feet above mean sea level. ${ }^{3}$

The Corps first suggested raising the pool in 1970 and, at the request of the Bureau of Indian Affairs, surveyed the potential effects on the in lieu fishing sites that it had finally acquired and, in some cases, improved for the Indians. That survey indicated that only Big White Salmon of the five sites would not be affected by the higher water levels. ${ }^{4}$

\section{More Money, More Delay}

The following year, the BIA obtained funds to build water and sewer systems on the sites but construction was delayed because of the plan to raise the pool level. Congress approved the full estimated cost of the construction, $\$ 211,000$, plus $\$ 24,000$ for maintenance for one year. Use of the money was restricted to building rest rooms, water and sewer systems and other waste disposal systems. "There were no suggestions or implications in the appropriations hearings or the legislation itself that permit their use for homesite development," the Inter-Tribal Commission briefing 
book stated. That did not prevent Treaty Indians of the Columbia from pressing BIA to use the money for better homes on the sites. The tribal governments of the Yakima and Warm Springs Tribes told the BIA, however, that they wanted the sites available to all tribal members for camping, boat launching, fish processing and other temporary uses and did not want homes there. The action was part of the long-time conflict between the tribal governments, who see themselves as custodians of the treaties and treaty rights, and the river Indians, who see themselves as the custodians of tradition and inherent rights never relinquished. A report at the time indicated 26 people lived "on or near" the sites year-round in addition to the 255 who used them periodically. ${ }^{5}$

On March 14, 1972, the Confederated Tribes of the Umatilla Indian Reservation and several individual members of the Yakima Tribe filed suit in U.S. District Court in Portland seeking an injunction against the Corps of Engineers' plan to raise the Bonneville pool. Judge Robert C. Belloni issued a preliminary injunction on March 30 but stayed its effect while the Indians and the Corps negotiated a settlement, which they did the following year. ${ }^{6}$

As part of the efforts to settle the suit, another search was made for additional sites and, for the first time, the discussion extended to sites on the backwaters of other dams. Officials decided the Cooks and Underwood sites were too small for sewer systems. Work at Lone Pine was delayed because Oregon Department of Environmental Quality regulations were made more stringent and the site's drain field was deemed inadequate for a septic system. So work was postponed pending the city 
of The Dalles' construction of a sewer system in the area, the north part of the city. The Warm Springs Tribal Council passed a resolution agreeing not to put permanent housing on the in lieu sites. The BIA suggested legislation to allow the Department of the Interior to acquire land, build homes and give them to Indians who had been displaced by the Bonneville pool and had not been compensated. ${ }^{7}$

In 1973, the Corps and the Bureau of Indian Affairs finally reached agreement on use of the $\$ 234,000$ appropriated in 1971 for improving the in lieu sites. In addition, the Corps completed its plan for altering the Bonneville pool and the Umatilla suit against the Corps was settled.

The memorandum of agreement between the two agencies of the federal government for spending the $\$ 234,000$, was attached to a letter dated May 16,1973 , from Col. Paul D. Triem, the Portland District Engineer for the Corps, to Dale M. Baldwin, Area Director of the BIA. It reads like an international treaty. In summary, the BIA agreed to pay its $\$ 234,000$ appropriation to the Corps, which agreed to design and supervise the construction of specific facilities. The work included either construction of waste disposal systems "or connection to existing systems as is the case for Lone Pine and Cascade Locks." The agreement provided for construction of:

1. At Wind River and Alternate Little White Salmon - new central water and sanitary facilities and fish cleaning and fish drying facilities.

2. At Big White Salmon - Expansion of the water system, provision of sanitary facilities and fish drying and fish cleaning facilities. 
3. At Cascade Locks - Connection to the city sewer system and construction of fish cleaning and fish drying facilities.

4. At Lone Pine - Expansion of the water system and new sanitary facilities with connection to a planned city sewage line; construction of fish cleaning and fish drying facilities.

The Corps agreed to do as much as it could with the money available and the BIA agreed to make the request for any additional money needed. The agreement also authorized the Corps to remove any existing facilities to accommodate the construction. ${ }^{8}$ BIA attempted to obtain an additional $\$ 800,000$ to pay for the construction but there was no appropriation or allocation. ${ }^{9}$

The Corps completed its plan for fluctuations of the Bonneville pool, including its effect on the Indian fishing sites, on May 24. The new operation was scheduled to begin with the winter of 1973-74 and the Corps planned to finish preliminary construction that October. However, the spring fish drying operations delayed work 14 days. ${ }^{10}$ The fluctuations eventually were delayed until December of 1974 because Congress had not enacted the necessary authorization. ${ }^{11}$

\section{Suit Settled}

Meanwhile, on August 17, Judge Belloni approved a settlement of the Umatilla Tribes' suit against the Army. The judgment stated that Maj. Gen. R. E. McConnell had testified March 15, 1973, at hearings before the House and Senate Appropriations Committees that the Corps planned to provide protection to three in lieu fishing sites 
at a cost of $\$ 430,000$. The work would include raising the lower portion of the sites and changing the shoreline to retain "substantially the same land area above the maximum high water levels." The judgment also stated that the Corps and BIA were proposing to the Office of Management and Budget that the existing in lieu sites be upgraded to National Park standards at an estimated cost of $\$ 1,091,000$. (The same recommendation, incidentally, is part of the current plan to improve the in lieu sites. According to Corps officials, the Park Service has told the Corps it has no specific standards for such facilities. ${ }^{12}$ ) The Corps also was recommending acquisition and improvement of additional sites. The judgment also took note of the Indians' continued concern about damage to the fish runs as a result of the dam operations, of the Corps of Engineers' promise to continue studies of the runs and of a Columbia Basin-wide study by the Corps of water resource management. The judgment directed that the Corps complete the protection of the existing in lieu fishing sites before it began the peaking fluctuations. It also directed that, "except in unavoidable emergencies," the Corps notify the Indians 60 days in advance of any changes in the operating limits then in effect for the Bonneville pool. ${ }^{13}$ In response to the settlement, the Corps built dikes to protect the sites. ${ }^{14}$

In 1974, the BIA proposed legislation authorizing the Corps of Engineers to improve the existing sites at a cost of $\$ 1,211,000$ and to acquire additional sites at a cost of $\$ 579,00$. No action was taken, but the Corps on November 28 awarded a contract for $\$ 296,240$ to build the sanitary facilities agreed on in the 1973 
memorandum of understanding. ${ }^{15}$ There is no explanation in available documents of how the Corps was able to award a contract for some $\$ 60,000$ more than was included in the appropriation. However, because the Confederated Tribes' judgment acknowledged that the in lieu sites were a responsibility of the Bonneville Dam project, it is likely the additional money came from other Bonneville funds.

\section{Keep Trying}

A ceremony was held in May 1975 to recognize completion of the sanitary facilities. By October, a BIA inspection of three of the sites revealed plumbing problems although the agency said there was nothing "of major concern." There is no record that any repairs were made. The next year, however, an unsuccessful attempt was made to get congressional authorization for the Corps to improve the fishing sites and to acquire and develop additional sites. Again in 1979, the Assistant Secretary of the Interior for Indian Affairs presented another bill that would authorize the Corps to improve the fishing sites. Congress took no action. The number of complaints to the BIA's area office in Portland indicated that three sites (not listed in the report) continued to deteriorate. Care and maintenance of the sites was delegated to the Yakima and Warm Springs Agencies of the BIA but questions about enforcement of rules governing use of the sites remained. Beginning in 1976, there had been reports of non-Indians using the sites for camping and picnicking and garbage cans had been stolen from the Big White Salmon site. ${ }^{16}$

Several other events related to the in lieu sites also occurred through the late 
1970s. In 1976, the government paid compensation to individuals who lost property flooded by the Bonneville pool. In 1977, the government granted a permit for establishment of fish buying stations at Underwood and Wind River on condition that fish sellers maintained certain conditions for water, power and sanitary facilities. In 1978, there was discussion, but no resolution, about getting money for the sites from Bonneville Power Administration on grounds that the acquisitions and improvements were classified as costs of Columbia River dam and reservoir projects. ${ }^{17}$

With the Celilo Fish Committee long since having disappeared from any of the correspondence or reports, the four tribes with treaty fishing rights established a new organization in 1977. Called the Columbia River Inter-Tribal Fish Commission, it brought together the Nez Perce, Umatilla, Warm Springs and Yakima Tribes. Although it is sometimes slow to act because of its requirement for consensus, the commission has developed a staff and expertise that make it a respected participant in Columbia River management. Formation of the commission, along with the stubborn campaign of David Sohappy for his right to fish and live on the Columbia, marks the emergence of the Indians into a major factor in the fisheries issue.

And as the decade ended the Indians won another major court victory. The United States Supreme Court upheld the 1974 ruling by Judge George Boldt that Belloni's "fair and equitable share" of the fish meant 50 percent. The reaction to the Boldt decision was especially venomous in Washington, where commercial and sports 
fishermen prodded state government to find away around Boldt and clamp down on Indian fishing. ${ }^{18}$ 


\section{NOTES}

1. Unsigned article, The Oregonian, Apr. 20, 1971, 1

2. U.S. Army Corps of Engineers, Final Phase Two Evaluation Report and Finding of No Significant Impact/Environmental Assessment, Columbia River Treaty Fishing Access Sites (April 1995), 1-5.

3. Final judgment, Confederated Tribes of the Umatilla Indian Reservation et al. vs. Howard Calloway, et al., Civil case No. 72-21 1, U.S. District Court for Oregon, Aug. 17, 1973.

4. Les McConnell, "In-Lieu Site Historical Summary," in Briefing Book on Indian InLieu Fishing Sites and Fisheries Law Enforcement on The Columbia River between Bonneville and McNary Dams (Portland: Columbia River Inter-Tribal Fish Commission, 1988), 19.

5. Ibid., 20.

6. Final judgment, Umatilla v. Callahan.

7. McConnell, Historical Summary, 20.

8. Memorandum of Agreement, May 16, 1973, Corps of Engineers, Portland District files.

9. McConnell, Historical Summary, 21.

10. Ibid.

11. Final judgment, Confederated Tribes v. Calloway.

12. Mike Allegre, unpublished interview with the author, Nov. 17, 1995.

13. Final judgment, Confederated Tribes v. Calloway.

14. McConnell, Historical Summary, 21.

15. Ibid.

16. Ibid., 21-22. 
17. Ibid.

18. Robert Clark, River of the West (New York: HarperCollins West, 1995), 336, 337 


\section{CHAPTER VII: THE EIGHTIES - EVICTION AND TRIUMPH}

\section{Arrests, Evictions \& Conflict}

Despite - or perhaps because of - the Indians' victories in the courts and increased tribal participation in fishery management on the Columbia, controversies over fishing grew increasingly nasty through the early 1980s. Federal and state government authorities, especially Washington state officials, blamed Indians for declines in the fish runs that resumed in 1978 after a brief upturn in the early 1970s. Disappearance of 40,000 salmon between Bonneville and McNary Dams prompted federal and state fisheries enforcement officials to launch a massive effort, popularly known as Salmonscam, to catch Indian salmon "poachers" in 1982. Ironically, the fisheries officials decided - after a dozen Indians were convicted - that the fish had spawned lower in the river as a result of an aluminum company chemical spill. ${ }^{1}$

Against this background, the Commissioner of Indian Affairs in 1981 made another effort to get congressional authorization to fulfill the 1939 agreement. The bill, identical to the 1979 proposal, called for improving the existing sites and acquiring additional sites to replace those lost to three dams - Bonneville, The Dalles and John Day. At some point, there was optimism that Congress would approve. At an enforcement meeting called by Oregon State Police, the issue of the in lieu sites was raised. "It has taken 40 years to acquire 40 acres for the use as described in the 1939 agreement," the Inter-Tribal Commission briefing book stated in its summary of the meeting. "Should the current proposed amendment to P.L. 14 (the original in lieu site 
legislation) be enacted by congress, more funding will be available at a later date." Congress, however, did not pass the bill.

In March of 1982, the Corps of Engineers demolished five Indian fishing platforms adjacent to the Lone Pine in lieu site. At the request of the Yakima Tribe, the BIA arranged a meeting April 3 in which the tribe asked the Corps both to explain its action and to replace the platforms. The Corps said it destroyed the platforms "for concerns of safety for the general public." The Corps was asked if it would comply with the 1939 agreement but its response was not recorded. The agency did agree to replace one platform. It also drew up a proposed use permit that the BIA refused to sign on grounds it was too restrictive and did not allow Indian fishermen free access to their platforms. The same year, the Inter-Tribal Commission established a fisheries enforcement office at Hood River and assigned officers to patrol the Indian fishing zone between Bonneville Dam and McNary Dam. Tensions continued to increase and the following year, the BIA sent a uniformed law enforcement officer to Stevenson, Wash., in an effort to defuse confrontations between Indian people living on nearby in lieu sites and the state and local authorities. ${ }^{3}$

In 1983, within months after the Salmonscam defendants were given sentences of one to five years in federal prisons, three Northwest Republican senators, Slade Gorton of Washington and Mark O. Hatfield and Robert Packwood of Oregon complained to Interior Secretary James Watt that the BIA's failure to evict the residents of Cooks Landing had allowed a permanent colony to develop there. ${ }^{4}$ BIA is 
an Interior Department agency and in March 1984, Stanley Speaks, the BIA Portland Area Director ordered the people living on the in lieu sites to move out within 30 days. By April 19 all personal property was to be removed from the sites. According to the Inter-Tribal briefing book, the official reason for the evictions was that the residences violated BIA regulations (adopted in 1969) specifically prohibiting permanent dwellings on the in lieu sites. The BIA offered to help the residents find other housing but said it would ask the U.S. Attorney to take legal action if the residents did not leave. One left; others appealed to higher BIA authorities. ${ }^{5}$

Elsewhere, other reasons were cited. Unidentified spokesmen for BIA in Portland told The Oregonian newspaper that the eviction notices were issued because other members of the treaty tribes had complained they were being denied access to the sites. Jack L. Schwartz, a Portland attorney who represented the site residents, suggested to the newspaper the evictions were retaliation for the government's limited success with "Salmonscam" prosecutions. Schwartz also contended that white sports fishermen and other non-Indians wanted to "clean up" the river shores by removing the Indians. The BIA contended that only a "handful" of Indians were affected by the order, but Schwartz estimated that about 50 lived on the five sites.

Chief Johnny Jackson of the Cascade/Klickitat bands, who still lives at the Underwood site (Big White Salmon), told the newspaper he also had received an eviction notice the previous year, which he ignored. "If they do get us out, the sportsmen are going to be all over," Jackson told the newspaper. "I've told them 
before I am not going to move. I am going by that treaty ... I asked them last year, where did they purchase that land?" David Sohappy, who lived on the Cooks Landing site (Alternate Little White Salmon), was a main target of Salmonscam and among those evicted. Jackson said Sohappy was targeted "because he is living in the traditional way." Jackson and Sohappy were among the site residents who appealed the evictions. The BIA agreed not to take legal action until a ruling on the appeal. ${ }^{6}$

The appeal through the BIA and the Department of the Interior bureaucracy bought the in lieu site residents two years. Meanwhile, neighbors of one site continued to complain, BIA turned down a chance to buy an additional site and a proposal to create a Columbia Gorge national scenic area threatened the ability of BIA to acquire more fishing sites for the Indians. In August 1985, the Port of Cascade Locks complained to the BIA that Indians were launching boats from the public boat ramp there, causing severe traffic congestion and restricting river access for non-Indians. The port boat launch was near the Cascade Locks in lieu site, which was on land where construction of a boat launch was impossible. The port asked BIA, however, to build a tribal boat launch and moorage on the Oregon side of the river, since neither Oregon site had a launching ramp.

During the year, a real estate agent sent the BIA a letter offering 78 acres on the Washington shore of the river for $\$ 130,000$ but the agency responded that it had no funds and no authorization for such a purchase. A citizens group drafted a proposed bill to create a national scenic area through the Columbia Gorge. A version of the 
measure would have made the Secretary of Agriculture the primary official responsible for four of the in lieu sites. The BIA offered substitute language to allow for future purchases of additional sites. ${ }^{7}$

\section{Bureaucracy The Winner - Temporarily}

On April 4, 1986, an administrative judge for the Interior Board of Indian Appeals upheld the BIA's order evicting the in lieu site residents. The BIA interpreted the ruling as upholding its authority "to regulate use of the fishing sites for the benefit of all Indians entitled to exercise treaty fishing rights on the Columbia River.” The BIA had concluded that permanent occupancy of the sites gave the residents an advantage that the agency could not give non-residents because of space limitations. The residents had argued both that the BIA lacked authority to adopt the regulations and that it had misinterpreted the regulations to preclude permanent residences. ${ }^{8}$ The administrative law judge, Jerry Muskrat, wrote that the regulation "clearly contemplates only the temporary use of the sites during the fishing season." So, he said, the BIA properly interpreted its own rule. However, he also said that the appeals board was not the place to consider the main argument made by the residents - that the regulation violated both the 1855 treaties and the 1945 law authorizing the sites. Muskrat said the appeals board had no authority to change BIA rules, only to determine whether an action violated those rules. Because the board could not change the rules, it refused to hear any arguments that challenged their validity, the judge said. Schwartz, the Indians' attorney, responded, "If the highest board inside the Interior 
Department can't say whether their own regulations are valid or not, they shouldn't use them."

Nevertheless, BIA officials said they hoped the Indians would comply with the Appeals Board ruling and move out. ${ }^{10}$ The residents, however, were not about to go without a legal fight. Nine individuals and "the chiefs and council of the Columbia River Indians" filed suit in U.S. District Court in Portland claiming that:

- The evictions violated both the treaties and the 1939 and subsequent agreements for acquiring and constructing in lieu sites.

- The BIA did not allow a hearing with evidence on the eviction notices.

- Eviction would take their property without compensation.

- The BIA had no authority to prohibit permanent residency on the sites.

- By allowing the Indians to remain on the sites for decades, the government had lost any right to evict them.

The complaint, filed by Schwartz and Gary M. Berne on behalf of the Indians, asked that the rule against permanent residences be declared invalid, that the BIA be required to comply with the treaties and agreements to replace three dozen fishing sites and that the court declare that the plaintiffs have a right to live on the sites. The complaint also asked for compensation for the Indians' property submerged by Bonneville Dam if the court decided they could not live on the in lieu sites. ${ }^{11}$

BIA officials contended they were seeking a peaceful solution to the dispute and that their top priority was a federal court decision upholding the regulation against 
permanent residences. ${ }^{12}$ While the suit climbed the rungs of the federal court system, the Indians remained in their homes. The dispute drew some public attention outside the Northwest. The BIA in Portland and Washington, D.C., reported receiving two letters a month from across the nation and Western Europe inquiring about the in lieu sites. $^{13}$

Despite the court action, the issue of additional in lieu sites remained on the BIA's agenda. In 1986, members of Congress from Oregon and Washington introduced a new bill to create a federally regulated scenic area in the Columbia Gorge, this time proposing a state commission to regulate land use. The BIA devoted some time to identifying potential fishing access sites along the river and submitted the information to the various parties working on the bill. The BIA also proposed bill language that would assure that additional sites could be purchased and developed later. $^{14}$

The Indians living on the in lieu sites lost the first round in federal court. In October 1987, U.S. Magistrate George Juba recommended that the Indians be evicted from the in lieu sites. Juba held that the 1855 treaties entitled the Indians to fish along the river but not to live there. ${ }^{15}$ Judge Helen Frye confirmed Juba's recommendation. The Indians appealed the ruling, won in the 9th Circuit U.S. Court of Appeals and finally won in Congress, but not until 1990.

As the legal action ground on, the BIA and its national leadership faced one of the attacks on its management and its existence that have dogged the agency through 
its history. Among those suggesting the bureau be abolished was its Director, Ross Swimmer, who told The Republic newspaper of Phoenix: "The best thing that could happen would be for the BIA to go away. Don't terminate the tribes. Terminate the BIA." Northwest Indians, however, suggested that Swimmer, not the BIA or the tribes, should go away. Schwartz, the in lieu site Indians' attorney, used the controversy to argue that the BIA "has attempted to destroy the Columbia River Indian community."16

Despite the turmoil over agency operations and the continuing legal action, the BIA made more efforts to resolve the in lieu site issue. On April 16, BIA staff members met with the Yakima Tribe to discuss refurbishing the boat ramp at the Wind River site, which had become so filled with silt that the river was too shallow for boat launching. As a result, Indian fishermen had essentially abandoned the area. In May, BIA officials met with the Corps of Engineers to discuss the possibility of dredging the boat launch area at Wind River. The Corps said it was possible and estimated the cost at \$1 million. Corps officials said the dredging would take two years and require special authorization.

With passage in 1987 of the Columbia River Gorge Scenic Area Act, the BIA also began negotiations with the Corps and the U.S. Forest Service, which was designated federal manager of the scenic area, to find property available for additional Indian fishing sites. The Corps and BIA requested and obtained land ownership maps of the river banks. In October, the two agencies began to discuss the possibility of transferring some Corps land to the Department of the Interior for the Indians. 
In January of 1988, the BIA provided the Corps with a map of the river banks showing areas that Indians, on yet another boat tour of the river, had selected as preferred fishing sites. Most of them were owned by the Corps. At the request of the Corps, the BIA on February 12 provided a list of eight key needs for the fishing sites, such as the capability of providing vehicle access from public roads and boat access to the river, and the improvements that would be needed, such as a source of potable water. On March 4 the two agencies discussed potential methods of acquiring the additional sites, either through legislation or agency transfers. The Corps said that any acquisitions would require an environmental impact statement because each of the suggested sites was near a railroad, near the river and within a national scenic area. On March 10, BIA notified the Corps it would not ask for an impact statement until it had discussed with the Indian tribes and other Indians the action they preferred. ${ }^{17}$

Early in 1988, U.S. District Court in Oregon approved the Comprehensive Fisheries Management Plan under the continuing U.S. v. Oregon case. As Melvin R. Sampson, chairman of the Yakima Tribal Council, described the plan on behalf of his tribe, "For the first time the United States, as well as the states of Oregon and Washington, has, in a written court order, accepted the primacy of the Yakima tribal fishery enforcement and management on the Columbia River." ${ }^{\text {18 }}$ The same, of course, was true of the other three treaty tribes.

\section{Congress Takes A Hand}

In 1987, the issue of the Indian sites had begun to draw some attention in 
Congress. Sen. Daniel Inouye, D-Hawaii, became chairman of the Senate Select Committee on Indian Affairs. He had taken an interest in the prosecution of David Sohappy and others in Salmonscam and in the federal attempt to evict the in lieu site residents, probably at the behest of Sohappy's attorney, Thomas P. Keefe of Seattle. Keefe was a former aide to Sen. Warren Magnuson, a Washington Democrat whose 41 years in the Senate overlapped Inouye's service by 18 years. Keefe, who has a flair for getting attention to issues of justice, undoubtedly drew Inouye into the Sohappy fray. Joining Inouye on the Indian Affairs Committee were Hatfield and Sen. Daniel J. Evans, a Washington Republican who did not have Gorton's record of opposition to Indians. Gorton, as Washington Attorney General, had vigorously pursued state charges in Salmonscam, led a state effort to nullify the Boldt decisions and prosecuted a variety of cases opposing Indian rights. Hatfield, despite signing the letter to Watts (which involved only sites on the Washington shore), had a history of helping Oregon tribes. By 1987, Gorton was no longer in the Senate, having been replaced by Democrat Brock Adams, who hired Keefe as an aide.

On April 19, 1988, the Indian Affairs Committee conducted an oversight hearing on the in lieu sites. In poignant and bitter testimony, Levi George, the chairman of the Yakima Nation's fish, wildlife and law and order committee, told the senators:

Our life today is tied to the river, even though our presently living elders hardly recognize the river they knew and worshiped only 50 years ago. In that 50 year period the Columbia has gone from a free flowing river of great beauty, full of life giving salmon and other nutrients for the Yakima people to a series of still water lakes through which our salmon must struggle for their existence. Under these lakes lies the heritage of the Yakima people. Gone are our traditional 
villages, camp sites, drying sheds, rapids and falls, and usual and accustomed fishing places, covered by these lakes in the name of progress. Also gone are many promises made to us by the white man during the building of these dams., including promises that fish ladders at the dams would fully protect our salmon, that our fisheries would not be lost through progress, and that our fishing places, at least in part, would be replaced by "in lieu" sites where we could camp, launch our boats, fish and prepare our catch ...

Bonneville was the first of these dams. The secretary of war promised and agreed that the United States would provide 400 acres of land along the Bonneville Lake for the use of Indian people as places "in lieu" of those destroyed by the flooding. Now, after 50 years, and the building of eight additional federal dams which destroyed the rest of our traditional acres, the United States has provided only 40 of the promised 400 acres.

In addition, George said, the sites were not adequately maintained and non-Indians "are trespassing on these sites with impunity." He recommended a five-point program to require the Corps of Engineers to identify all its lands that would make suitable fishing sites, to begin development immediately on the suitable sites already owned by the Corps and to obtain funds for operation and maintenance of all the sites. ${ }^{19}$

George's testimony was echoed by Delbert Frank, Sr., vice chairman of the Tribal Council of the Confederated Tribes of the Warm Springs Reservation:

Additional in lieu sites are badly needed throughout the Columbia River Indian fishing area. There are more than 16,000 members of the Warm Springs, Yakima, Umatilla and Nez Perce Tribes with treaty fishing rights in Zone 6, the 140-mile stretch of the Columbia River between Bonneville and McNary dams which is an exclusive treaty Indian fish area. More than 300 fisherman have participated in recent fall commercial seasons, and a large number of tribal members fish the Columbia for subsistence purposes throughout the year. With an interstate freeway along the Oregon shore and a state highway and large parcels of private land along the Washington shore, the Indian people have a hard time simply getting to the river to exercise their fishing rights ... 
Frank asked the committee to "help to fulfill a promise made to the Indian people more than 50 years ago by the federal government when Bonneville Dam was constructed." ${ }^{20}$

Congress acknowledged the problems in the report accompanying H.R. 2677, which was passed late in 1988. Indian access to the river all along the Columbia is largely "through private lands and public parks, increasing tensions between the Indians and the general public and taxing public park facilities which are not equipped for Indian treaty fishing activities," the report stated. "Highways, railroads and fences further hinder access. Also, a phenomenal recent influx of windsurfing or boardsailing in the Columbia Gorge has increased overcrowding and tensions. Finally, facilities at the existing in-lieu sites are in dire need of repair."

Before passage of the bill, Senators Hatfield and Evans wrote to Major General Henry Hatch, Chief of the Corps of Engineers, on August 3 suggesting that the Army could make sites it owned available for Indian use without time consuming environmental impact statements. "We are most anxious for the Corps to effectuate the transfer of sites before further tension and overcrowding causes [sic] irreparable harm to the many parties with an interest along the Columbia," they said.

The Corps' Director of Civil Works, Brig. Gen. Patrick J. Kelly replied on September 6, contending that the Corps had fulfilled its obligation under the 1945 legislation. Transfer of Corps lands to Indian usage would require congressional authorization, he said. In addition, the Corps was to begin preparing a master plan for 
Columbia River operation that fall and could not declare any of its lands surplus to the needs of its river projects until the plan was completed. Kelly referred to meetings through the summer between Corps staff and staff members for the two senators in Portland. The master plan would require public comment, he said. However, the Corps had mapped 30 sites suggested by the Columbia River Inter-Tribal Fish Commission. "Any recommendations will be based on regional needs, agency and public involvement and resource suitability," Kelly said.

In September of that year during the Indian Affairs Committee's work session on a House-passed bill dealing with other Indian issues, Evans introduced an amendment designed to fulfill both the 1939 agreement and the 1973 agreement settling the lawsuit over fluctuations of the Bonneville pool. The committee approved the amended bill on September 21 and the bill was signed into law by President Reagan on November 1.

The bill:

- Required federal agencies owning several pieces of land along the river to administer them as Indian fishing sites and ordered that improvements be made to those sites.

- Ordered the Corps of Engineers to identify all land for sale adjacent to the Bonneville pool and acquire at least six sites on the Bonneville pool after consulting with the Indians.

- Ordered the Corps to develop the sites to National Park Service standards for 
improved campgrounds.

- $\quad$ Said costs of the acquisition and improvement would be charged to the Columbia River dam projects.

- $\quad$ Authorized spending up to $\$ 2$ million.

- Gave the Secretary of the Interior right of first refusal in acquiring any lands another agency made available.

- $\quad$ Limited the acquisitions to 360 acres. ${ }^{21}$

According to a fact sheet supplied by the office of Sen. Brock Adams, D-Wash., the bill identified 23 sites. Two of the sites listed on the Washington shore, North Dalles and Maryhill, were not owned by the federal government and so were not immediately subject to provisions of the law. Eight of the sites would impact public facilities such as boat ramps, access roads, parking areas and sanitary facilities: Avery, six miles above The Dalles Dam in Klickitat County, Wash.; Preachers Eddy, one mile east of Rufus in Sherman County, Ore.; Cliffs, one mile downstream from John Day Dam in Klickitat County, Wash; LePage, near the mouth of the John Day River in Sherman County, Ore.; Sundale, near the community of Sundale in Klickitat County, Wash.; Roosevelt, near the old Arlington-Roosevelt Ferry in Klickitat County, Wash.; Threemile Canyon, 2.5 miles east of Willow Creek in Morrow County, Ore., and Crow Butte, on Crow Butte Island in Benton County, Wash. The bill also ordered dredging at the Wind River site and construction of a boat ramp at Cascade Locks. The fact sheet noted that the law set no time table for the acquisition or improvements and 
added, "It is known that a multi-year program will be necessary ..."22

\section{Delay and Disagreement}

That assessment was certainly correct. When construction finally began in 1995 , the Corps of Engineers estimated all the work would be finished by 2002, 63 years after the Corps promised six sites and 400 acres and 14 years after the bill was signed into law. These later delays appear to be almost largely due to the pace of the Corps of Engineers' process for carrying out the law.

Eight of the 21 sites listed in the bill were already developed for public use and the Corps' first reported action in response to the bill was to announce on May 1, 1989 , that those sites would be shared by the public and the Indian fishermen for the remainder of 1989. After that, said Col. Charles Cowan of the Corps' Portland District, the Corps and the Bureau of Indian Affairs would negotiate the use of the sites annually until the Corps finished a study of the sites and they were set aside exclusively for Indian fishing as directed in the law. Congress made no provision for additional areas of public access to the river. Cowan said the Corps planned to hold half a dozen meetings to describe the law and hear public comment. Speaking at the same news conference, Delbert Frank, Sr., vice chairman of the Warm Springs Tribal Council, said, "The sites described in the new legislation are places our people have fished for generations, not for sport or recreation, but for survival."${ }^{, 23}$

It took just about a week for non-Indians to start raising objections. On Thursday, June 1, 1989, both outdoor columnists for The Oregonian reported public 
opposition to setting the sites aside for the Indians. "The question of public access is howling like a gorge wind on a 130-mile stretch of the Columbia River between Bonneville and McNary dams," Tom McAllister opened his report on the issue. He reported that the Oregon Marine Board, Fish and Wildlife Department, Parks Division and Police had agreed on a six-point position statement. Key elements were support for improved river access for both tribal fishermen and non-Indian recreation users of the river. The state agencies also said they wanted to participate in the final plan and urged local "public reviews" of the plan. McAllister also offered a sample of non-Indian opinion: "River access points are already overcrowded, and now they'd be taking away our boat ramp at Rufus and building another for the Indian fishermen a few miles upriver at Preachers Eddy," said Hobart Manns of Gresham. McAllister also quoted John Thomas, president of the White Salmon River Steelheaders, who shared the Big White Salmon site with the Indians by agreement. "We've co-existed all this time with our Indian friends," he said. If the new law forced the non-Indians off the site, they would face a five-mile run on sometimes dangerous water to reach the White Salmon River. ${ }^{24}$ Bill Monroe reported that tribal leaders said they would lobby for replacements for non-Indians of the recreation facilities the Indians were taking over. Monroe also quoted Levi George of the Yakima Nation and Delbert Frank, Sr. of the Warm Springs Tribes as believing that conflicts between recreational and tribal fishermen had eased in recent years. The tribes were, however, nervous about the growing number of windsurfers, who they said paid no attention to existing uses of 
facilities, blocked boat ramps and sometimes cut nets. ${ }^{25}$

The first of the Corps' public meetings on the new law took place August 2 at The Dalles and The Oregonian reported that some speakers were highly critical of the new law and of Indian fishermen. One person, Mark Weston of The Dalles, accused Indian fishermen of taking over the river. Two Indian fishermen said conflicts arose with sportsmen because the tribal fishermen require boat ramps for lengthy periods to load and unload gear and unload fish. Nez Perce tribal member Loretta Halfmoon said employees of the Corps, windsurfers and others had harassed members of her family. ${ }^{26}$ Similar meetings were held later that month in Hood River, Ore.; Goldendale, Wash.; Boardman, Ore., and Richland, Wash. At the final session, The Oregonian reported, "Angry sport fishermen have sharply criticized the federal government for designating 23 Columbia River fishing-access sites for Indian fishermen only." "I don't understand why we can't use them equally," said James A. Bates of Kennewick, Wash. "I want use of those facilities." Kathryn Brigham, a Umatilla tribal member serving on the in lieu site task force, tried to smooth the conflict, saying, "The tribes want to work with you to meet your needs and our needs." George Miller, a planner for the Corps, said the intent of the law was to separate commercial and sport fishermen, who required different amounts of space. ${ }^{27}$

By October, the Corps was working on an "interim plan" to keep all the sites open to non-Indians. Dick Webster, chief of the Corps' natural resources management section for the Portland District, told The Oregonian the Corps wanted to work out a 
multi-year agreement with the tribes and Bureau of Indian Affairs for joint use of the sites. He hoped the interim plan would be ready for public review the following spring. He conceded that if the Corps followed the letter of the law, it would have to begin immediately to administer the contested sites exclusively for Indian use. ${ }^{28}$

The in lieu site law also figured in the U.S. 9th Circuit Court of Appeals hearing on the efforts to evict permanent residents of the existing in lieu fishing sites. During the May 1, 1989, hearing in Portland, Judge Robert Boochever asked government attorney Angus E. Crane if the new law would change the Secretary of the Interior's view on the eviction case. Crane said he had not talked to the Secretary, Manuel Lujan Jr. Judge Alex Kozinski said he found it amazing that Crane had not discussed a possible change in stance with his client, the Secretary. Crane argued that other tribal members were intimidated by presence of the permanent residents and that, with 13,000 tribal members guaranteed river access "it would be almost inconceivable that the sites could hold permanent residences." An attorney for the Indians, Gary M. Berne, said the government in the 1930 s, 40s and 50 s had told the Indians, "We will replace the land, we will replace the buildings. Then they didn't do that."29 


\section{NOTES}

1. Bill Curry, Los Angeles Times, Aug. 3, 1986, A-1.

2. McConnell, Historical Summary, 22.

3. Ibid., 23.

4. Clark, River of the West, 357, 358 .

5. Ibid.

6. Jeanie Senior, The Oregonian, Apr. 16, 1984.

7. McConnell, Historical Summary, 23-24

8. Ibid., 24-25.

9. Jeanie Senior, The Oregonian, Apr. 25, 1986.

10. McConnell, Historical Summary, 25.

11. Second amended complaint, Sohappy v. Hodel, Civil No. 86-715-JU, U.S. District Court for Oregon, Oct. 23, 1986.

12. McConnell, Historical Summary, 25.

13. Ibid., 26.

14. Ibid., 25.

15. Dave Hogan, The Oregonian, Oct. 27, 1987.

16. Barnes Ellis, The Oregonian, Nov. 15, 1987.

17. McConnell, Historical Summary, 26.

18. Melvin R. Sampson, testimony before the House Appropriations Subcommittee on the Interior, Mar. 2, 1988.

19. Levi George, testimony to the Senate Select Committee on Indian Affairs, Apr. 19, 1988. 
20. Delbert Frank, Sr., testimony to the Senate Select Committee on Indian Affairs, Apr. 19, 1988.

21. Report to accompany H.R. 2677, Senate Report No. 100-577, 100th Congress, 2nd Session Sept. 30, 1988.

22. Fact sheet, office of Sen. Brock Adams, undated.

23. Jeanie Senior, The Oregonian, May 26, 1989, E06.

24. Tom McAllister, The Oregonian, June 1, 1989, C06.

25. Bill Monroe, The Oregonian, June 1, 1989, C06.

26. Jeanie Senior, The Oregonian, Aug. 4, 1989, C14.

27. Dick Cockle, The Oregonian, Aug. 19, 1989, D04.

28. Ibid., Oct. 26, 1989, E04.

29. Jeanie Senior, The Oregonian, May 2, 1989, D08. 


\section{CHAPTER VIII: THE NINETIES - A SHOVELFUL OF DIRT}

\section{OK To Stay}

As the Corps of Engineers proceeded methodically to plan development of the sites, the eviction case proceeded slowly through the courts. In 1990, the Corps began a preliminary engineering and design program, dividing the sites into two groups to in the Army's words - "accelerate implementation." The first shovelful of dirt was turned five years later. ${ }^{1}$ How long would it have been had the program not been "accelerated?" There is no evidence now that the long time lag from beginning design work to construction was the result of anything except that the processes of government grind exceedingly slowly. If there was no urgency evident, there also is no indication of deliberate delay. The work included not only studies of each site, but detailed plans with engineers' drawings for camping sites, parking areas, dumpster pads, vault toilets and vegetation plantings at each site. For some sites, there were alternate plans.

Also in 1990, the 9th U.S. Circuit Court of Appeals reversed the order evicting the Indians from their homes on the in lieu sites. ${ }^{2}$ The Appeals Court, in the August 3 decision, said the in lieu sites were subject to the same conditions as the 400 acres of fishing sites that the Indians had lost to the rising waters of the Bonneville pool. By allowing year-around dwellings on the sites until 1969 - the year it ordered the evictions - the Bureau of Indian Affairs implied that the treaties allowed the sites to serve as permanent residences, the Appeals Court said in a 2-1 ruling. However, it sent 
the case back to the U.S. District Court in Oregon to determine conditions that governed the treaty fishing sites that had been lost. Judges Thomas Tang and Robert Boochever provided the majority opinion; Judge Alex Kozinski dissented. ${ }^{3}$

Congress stepped into the dispute that fall when Sen. Brock Adams, a Washington Democrat, inserted a provision in the Interior Appropriations Bill prohibiting use of any of the department's money to evict the in lieu site residents unless a final court order of eviction had been signed. The accompanying report directed the Interior Department to reevaluate the assumptions that led to the decision to evict the Indians. ${ }^{4}$ The BIA, which initiated the evictions, is an agency of the Interior Department. The following year, on Sept. 5, U.S. Magistrate George Juba signed the order acknowledging the right of the nine Indian plaintiffs to live on the sites. The action came too late for David Sohappy - he died May 7, five months before Juba signed the order. The chief issue Juba was called on to decide was whether Indians had lived on the original fishing sites. "We had pictures of houses there in 1937," said Gary N. Berne, who represented the Indians. Without taking additional evidence Juba signed the order. ${ }^{5}$ At least several of the Indians still live at Cooks, Underwood and Cascade Locks.

Meanwhile the Corps managed the additional sites designated in the 1988 law in consultation with the four tribes and the BIA. At the same time, the Corps was updating its master plan for managing the Bonneville, The Dalles and John Day Locks and Dams. That study included an analysis of the effects of the Indian fishing sites on 
federal lands surrounding the three dams. It also included identification of areas with river access that could be developed either for Indian fishing sites or for public recreational sites. In addition, the corps wrote general design criteria for fishing sites, publishing its findings in two manuals covering sanitary facilities, water distribution systems, highway approaches, boat ramps and railroad crossings. Much of this material was contained in Columbia River Projects, Master Plan for Resource Use, Columbia River, Oregon and Washington, Working Document - Development Suitability Analysis of Critical Management Units, Portland District, December $1990 .^{6}$

At the same time, the Corps was working on a two-year preconstruction engineering and design study. This Phase One Report, submitted to the assistant secretary of the Army for civil works March 3, 1993, dealt with development of four sites: Bonneville Area Office, one of the new sites designated in the 1988 legislation, and Cascade Locks, Underwood and Lone Pine, three of the original in lieu sites. These sites were picked for early development because they presented the fewest problems. The boundaries did not require changes that would need congressional authorization. They would have little environmental impact. The three existing sites had the highest use by tribal fishers and provided better river access for the tribes in areas where there are conflicts between Indian fishers and recreational users of the river. The old sites had boat ramps, drying sheds and sanitary facilities but all needed rehabilitation. The Corps expects to have the work finished and turn them over to the BIA in 1996. Total cost was estimated at $\$ 7,660,000{ }^{7}$ 


\section{Beginning to Buy}

The Corps also set about acquiring the six additional sites on the Bonneville pool as required in the 1988 legislation. It hired the Portland engineering consulting firm of David Evans and Associates to identify potential sites. The company found 58 possible sites. A review by Corps staff cut the number to 35, eliminating sites where there was poor access, critical wildlife habitat or unstable slopes. The company, in its November 25, 1991, report, ranked the development potential of the sites, listing 14 as good and seven as moderate. The Corps then contacted owners of the property seeking willing sellers. It found $14 .^{8}$ Eventually, the Corps selected six sites to purchase and in March 1994 asked for public comments on them. ${ }^{9}$ No sites had been purchased by late 1995. The Corps believes the $\$ 2$ million it is allowed to pay for the additional sites will run out before it has acquired the 360 acres the 1988 law authorized. Before purchasing property the Corps was preparing a "real estate design memorandum" to govern the purchases, which were scheduled to begin in $1995 .^{10}$

The 1988 legislation listed 22 sites along The Dalles and John Day pools that were to become treaty fishing access sites. Two of those, however, were not managed by the federal government and they were dropped from the plans, leaving 20 sites to be developed. The Corps had leased part of another site to the city of Boardman, which had built part of its water supply system on the land. An Indian fishing site would affect the water supply and that site too was eliminated, leaving 19. Another site, aptly named Cliffs, was deemed too steep for development and an area at Maryhill State 
Park across the river from Biggs, Ore., was substituted.

Treating the sites as a system of related developments rather than single projects, the Corps studied, consulted and wrote plans. Consultation with the tribes led to some site boundary adjustments and selection of some alternate sites. The Corps did an environmental assessment required by the Environmental Protection Act and found no significant impact on the environment. Finally in January 1995 it issued its draft Phase Two Report - two volumes a total of $2 \frac{1}{2}$ inches thick - and called for public comment. In April, it issued the final report, little changed from the draft. Then the Corps was ready to go to work."

Some studies continued into late 1995, however. The Phase Two Report notes that eight of the treaty fishing access sites designated in the legislation are used for public access to the river. The public and tribal fishing usage exceeds the capacity of the sites. The Corps is authorized to develop only treaty fishing access but is feeling "strong public pressure to preserve public river access and recreation facilities" at the sites. The tribes and BIA want to avoid public criticism for the loss of public access to the river. At the locations with conflicts, the Corps said, "alternatives to provide separate fishing access for the Tribal fishers will be investigated."'2

The 19 sites remaining from the congressional list, or substituted for a site designated in the 1988 law, on The Dalles pool:

- Avery, in Klickitat County, Wash., at river mile 197.4 (measured from the Pacific Ocean)

- Celilo, in Wasco County, Ore., adjacent to a developed Corps of Engineers 
park on the site of the old Celilo village, at mile 201.5

- Maryhill, in Klickitat County, Wash., adjacent to Maryhill State Park just east of the Highway 97 bridge at mile 208.2

- Rufus, in Sherman County, Ore., mile 212.5

- Preachers Eddy, in Sherman County, Ore., near Giles French Park at mile 213.5

Sites on the John Day pool are:

- North Shore, in Klickitat County, Wash., near John Day Dam, at mile 215.9

- LePage, in Sherman County, Ore., in LePage Park, at mile 217.8

- Goodnoe, in Klickitat County, Wash., at mile 225.4

- Pasture Point, in Klickitat County, Wash., at mile 226.5

- Rock Creek, in Klickitat County, Wash., at mile 227.5

- Sundale, in Klickitat County, Wash., at Sundale Park, mile 236.2

- Roosevelt, in Klickitat County, near the town of Roosevelt, at mile 241.0

- Moonay, in Klickitat County, at mile 247.5

- Pine Creek, in Klickitat County, Wash., at mile 250.2

- Threemile Canyon, in Morrow County, Ore., at mile 255.0

- Alderdale, in Klickitat County, Wash., at mile 257.5

- Alder Creek, in Klickitat County, Wash., at mile 258.0

- Crow Butte, in Benton County, Wash., on an island, divided between the Washington State Parks Commission and Umatilla National Wildlife Refuge, at mile 262.0

- Faler Road, in Morrow County, Ore., at mile 267.5 
The Corps found impediments to developing many of the sites. Some were narrow strips between railroad and river. Others were accessible only on steep roads. Some were subject to flooding or earth slides. The Corps recommended alternate sites for Roosevelt, North Shore and Crow Butte and boundary changes for a dozen others. ${ }^{13}$ Ironically, while the Corps plodded along with its planning and report writing, the number of salmon in the Columbia continued to drop and Indian fishing was severely restricted. In 1991 and 1992, the Snake River chinook and sockeye runs that make up a major share of the Columbia River fishery were listed for protection under the Endangered Species Act. ${ }^{14}$ Since then, the tribes have struggled to catch enough salmon for their spring ceremonies and commercial fishing has been reduced to a fall season of a few days. ${ }^{15}$

Finally, on November 17, 1995, representatives of the four tribes, wearing traditional garb, turned over symbolic shovelsful of mud to mark the beginning of construction on the first of the new sites, on the Washington shore near Bonneville Dam. ${ }^{16}$ The Corps' plan says all the sites will be finished by $2002-63$ years after the Corps agreed to replace 40 flooded sites with six totaling 400 acres. The current plan will provide 31 sites totaling 335 acres on the pools of three dams, instead of Bonneville alone. There will be no homes built to replace those flooded behind Bonneville Dam. But the water supplies, drying sheds and boat launches are in the plan. ${ }^{17}$ 


\section{NOTES}

1. U.S. Army Corps of Engineers, Final Phase Two Evaluation Report and Finding of No Significant Impact/Environmental Assessment, Columbia River Treaty Fishing Access Sites (April 1995), Executive Summary, S-1.

2. The Oregonian, Aug. 4, 1990, E01.

3. Ibid., Aug. 4, 1990, E07.

4. Roberta Ulrich and Alan Ota, The Oregonian, Oct. 28, 1990, E06.

5. Fred Leeson, The Oregonian, Sept. 6, 1991, C04.

6. Corps of Engineers, Phase Two Report, 1-8, 1-9

7. Ibid., EA-8, 4-13 5-1.

8. Ibid., 1-6, 1-7.

9. Richard Cockle, The Oregonian, Mar. 24, 1994, B02.

10. Corps of Engineers, Phase Two Report, 4-6, 4-7.

11. Ibid., 1-19, 20.

12. Ibid., 2-17.

13. Ibid., $2-3$ to $2-13$.

14. Paul Koberstein, The Oregonian, Apr. 18, 1992, A01.

15. Roberta Ulrich, The Oregonian, Apr. 7, 1995, B01.

16. Roberta Ulrich, The Oregonian, Nov. 18, 1995, C01.

17. Corps of Engineers, Phase Two Report, 3-2. 


\section{CHAPTER IX: CONCLUSION - BLAME TO SHARE}

\section{Reasons and Excuses}

This 60-year saga of the Indians' efforts to get the United States government to fulfill a promise made in apparent good faith fits a pattern. Not until the Indian Claims Commission Act of 1946 could tribes so much as file a land claim against the government without special legislation, which Congress only rarely approved. ${ }^{1}$ The most notable example of delay may be a land claim by the Oneida Tribe of New York dating to 1795 . The tribe filed suit in 1970 and the Supreme Court ruled in its favor in $1985 .^{2}$ Closer to the in lieu issue, the Colville Indians of Washington state finally began receiving payments in 1995 from Grand Coulee Dam revenues based on an agreement reached in the $1930 \mathrm{~s} .{ }^{3}$ In the issue of Bonneville Dam in lieu fishing sites there is no single explanation for the delay. Nor is a single individual, agency or political agenda responsible. Rather, there is a tangle of larger issues, changing policies, good intentions gone awry and procedural impediments that combined to prevent the promise from being fulfilled.

First, larger issues overshadowed the Indians' interests. When Bonneville and Grand Coulee Dams were being planned in the 1930s, the nation was focussed on alleviating the unemployment of the Depression and on potential growth of the Northwest population and economy. The public was thinking of electric power, irrigation and river transportation. Even fish passage over Bonneville came as an afterthought. News stories of the time emphasize relocation of railroads and highways 
and compensating landowners for the dam site and property that would be flooded by the pool behind the dam. Only after preliminary work began was there a mention of fish passage facilities - in the seventh paragraph of an Oregon Journal story. "Another problem for the engineers is the planning of fishways," the story said, adding that no fish passage had ever been built over a structure as high as the dam but "confidence is expressed" that it could be done. ${ }^{4}$ Not until 1937 did an Indian agent raise the issue of fishing sites.

To give the Corps of Engineers its due, the records give every indication that the Corps was fully prepared to carry out its commitment in 1941. The Army included $\$ 50,000$ in its appropriations bill that year to acquire and develop the six sites covered in its agreement with the tribes. The United States' entry into World War II changed all that. President Roosevelt vetoed all new construction and, along with all other civilian construction, the in lieu sites went on hold for the duration. Once the war was over, the Army again obtained an appropriation in 1945 and appeared willing to proceed. ${ }^{5}$

However, growth was once more the driving public force and the Corps had grander things on its agenda than a few little Indian fishing sites. The nation was prepared for a burst of construction, including all-out development of the hydropower and navigation potential of the Columbia and Snake Rivers. This was the kind of thing the Corps boasts about in its official histories - big projects with big results. ${ }^{6}$ For the most part, the dam projects also were popular in the region, where exponents of 
growth saw a vibrant economic future. Only a few Indians, fishermen and environmentalists grumbled that the dams would wipe out the salmon. Thus, the nagging problems of acquiring land and getting tribal agreement for site changes took a lower priority than building more electrical power plants.

Northwest political power in both parties was devoted to pulling in ever more appropriations for developing the Columbia, not mitigating damage done by development. State governments in both Oregon and Washington, and especially in Washington, traditionally were hostile to Indian interests, particularly to Indian treaty fishing rights. Many of the major U.S. Supreme Court rulings on Indian fishing rights have come from the Northwest, based on those state-Indian conflicts, beginning in the early 1900s. Both states, spurred on by politically influential sports and sometimes commercial fishing interests, long tried to control Indian fishing. There is some evidence that congressional influence was exerted to delay a site at least once in the 1950 s and to evict Indians from lieu sites in the 1980s. Only in the late 1980s did the Indians find some allies in Congress to push their case.

There were devoted people in the Indian Service, later Bureau of Indian Affairs, who tried to help the Indians. However, interest at the higher levels of the agency, at least judging from correspondence files, was moderate at best. Through most of the period, the agency engaged in changing policies toward the Indians. Only a few years before the fishing sites became an issue, federal policy reversed from weakening tribes and assimilating their members into the larger society. ${ }^{7}$ Thus, the tribal governments 
were only beginning to gather strength in the early years of the struggle for the sites. William Brophy, who headed the BIA in the post World War II years, devoted his efforts to decentralizing the administration of Indian affairs. At the same time, Congress showed growing hostility to the agency. In the Eisenhower Administration of the 1950s, government indifference to treaties and Indian welfare culminated in the termination policy, which ended federal recognition of dozens of tribes, including the Klamaths in Southern Oregon and all the tribes of Western Oregon. ${ }^{8}$ There must have been some feeling that all tribes, including those who fished in the Columbia, eventually would be terminated and that would solve the site problem.

\section{Justice Delayed ...}

At times, the correspondence indicates that the governmental agency that was supposed to serve as the tribes' advocate, the BIA, attempted to push the Corps to go ahead with development. At other times, it appeared to require procedures that delayed decisions. In any event, the agency had little influence in either the executive branch or the Congress. What little influence it did have was used in obtaining a financial settlement for the tribes for the loss of the Celilo fishery from the construction of The Dalles Dam. Even there, the tribes' own attorneys negotiated the $\$ 23$ million settlement.

State officials blamed poaching and overfishing by the Indians for the dwindling fish runs of the $1960 \mathrm{~s}, 1970$ s and 1980s. Insisting on their treaty right to fish, the river Indians and fishers from the reservations defied state efforts to force them off the river. 
Their insistence on exercising their treaty rights overshadowed the in lieu site delays and won them no support from the non-Indian population. Political efforts were focused on ways to stop Indian fishing, not provide them more places to fish. The Indians kept winning in court, further angering non-Indian fishers and some members of Congress. Many Indians attribute Sen. Slade Gorton's relentless efforts to halt Indian fishing in the 1980 s and to cut back Indian programs in the 1990 s to his court losses on Indian fishing cases when he was Washington's Attorney General. Jack L. Schwartz, a Portland attorney who represented the Indians evicted from homes at the in lieu sites, summed up the attitudes best:

The plan is to get rid of the Indian fishery. The public position of the government is that the Indians are harming the fishery - and thus the white sport and commercial fishery. The Indians are the weakest politically and financially, so they get hit. ${ }^{9}$

The protracted prosecution of Indian fishermen coupled with the legal battle over the evictions finally brought national publicity and considerable sympathetic public attention to the Columbia River fishermen, providing impetus to push through Congress a new in lieu site program to settle the matter once and for all. In addition, tribal governments were growing stronger and their lobbying more sophisticated. Counterbalancing the publicity advantage, however, were the increasing population in the Columbia River Gorge and the rise in popularity of wind surfing. The combination increased non-Indian use of every access spot along the river and brought wind surfers into conflict with fishermen over nets and space. These conflicts were evident in the public meetings described in Chapter VII. The Corps' reluctance to annoy the portion 
of the public who complained about sharing access with Indian fishers is recorded in its report on the Indian sites. ${ }^{10}$

In some respects, the Indians hurt their own cause. There was rivalry between tribes, as when the Yakima Nation attempted to exclude the Warm Springs from the sites on the basis of the bogus 1865 "treaty." There was, and is, conflict between the tribal governments and the traditionalists who continue to live along the river aloof from the reservations. The Indian tradition of making decisions by consensus, rather than majority vote, often delayed a united stance. At least in the early years, the Indians seemed not to understand why the Corps could not simply give them the land and build the promised facilities. And the Corps and other government agents seemed to chafe against the traditional Indian negotiations in which each individual has his full say without interruption before any action is taken. For a number of years, many of the Indians active in the site issue did not speak English, further slowing communication. Army bureaucrats' frustration may have made it possible to put the in lieu site issue aside by blaming the Indians' failure to agree on specific actions. On the other hand, there is no explanation of the Corps' refusal to go ahead with the sites on which it did have full tribal agreement. Eventually, it did so but only after a delay of several years. Whether there was some political pressure to find an excuse for delay or whether the insistence on all or none was simply the Army's devotion to orderliness is impossible to determine from records currently available. In this case, the latter reason seems more likely. 
Finally, the years of delay since 1989 appear due mostly to the complicated, time consuming process of planning a government project. With its big Columbia construction works behind it, the in lieu sites are almost all that is left in new construction. They are hardly of a scale that incites enthusiasm among engineers, but the sites are getting the full Corps treatment of study and planning. And that takes time.

In summary, there is no one reason that the federal government has taken nearly six decades to fulfill a seemingly simple promise. But the saga of delay illustrates what can - and does - happen to a politically powerless minority in a democracy. The tribes are no longer powerless; they share management of the Columbia River salmon with the states and federal government. But their wait for justice has been far too long. There are few fish in the Columbia now and fishing is severely curtailed. Johnny Jackson, who is 64 and chief of the Cascade/Klickitat tribes, has spent his adult life fighting for the in lieu sites. As ground was finally broken at Bonneville November 17, 1995, Jackson summed up the sadness: "Many of my elders died waiting for this day." 11 


\section{NOTES}

1. Donald L. Parman, "Inconstant Advocacy: The Erosion of Indian Fishing Rights in the Pacific Northwest, 1933-1956," in The American Indian Past and Present, 4th ed., ed. Roger L. Nichols (New York: McGraw-Hill Inc., 1992), 245.

2. Charles F. Wilkinson, American Indians, Time and the Law (New Haven: Yale University Press, 1987), 41.

3. Roberta Ulrich, The Oregonian, Aug. 7, 1994, A01.

4. "Bonneville Job Billed for Action," Oregon Journal (Portland), Oct. 1, 1933, 1.

5. Parman, Inconstant Advocacy, 245.

6. For example, William F. Willingham, Water Power in the Wilderness, 1982, and Army Engineers and the Development of Oregon, 1983 (both Portland: Army Corps of Engineers).

7. Theodore W. Taylor, The Bureau of Indian Affairs (Boulder, Colo.: Westview Press, 1984), 20, 21.

8. Parman, Inconstant Advocacy, 246.

9. Jack L. Schwartz quoted by Bill Curry, Los Angeles Times, Aug. 3, 1986, 16.

10. U.S. Army Corps of Engineers, Final Phase Two Evaluation Report and Finding of No Significant Impact/Environmental Assessment, Columbia River Treaty Fishing Access Sites (April 1995), 2-43, 2-67.

11. Johnny Jackson, quoted by Roberta Ulrich, The Oregonian, Nov. 18, 1995, C01. 


\section{BIBLIOGRAPHY}

\section{Articles and Books}

Uncommon Controversy: Fishing Rights of the Muckleshoot, Puyallup and Nisqually Indians, a Report Prepared for the American Friends Service Committee. Seattle: University of Washington Press, 1970.

Clark, Robert. River of the West. New York: HarperCollins West, 1995.

Cockle, Richard. "Deadline nears for public views on fishing sites." The Oregonian (Portland), Mar. 24, 1994.

. "Non-Indians battle for 23 fishing spots." The Oregonian (Portland), Aug. $19,1989$.

Curry, Bill. "Light Is Growing Dim for Columbia River Indians." Los Angeles Times, Aug. 3, 1986.

Dodds, Gordon B. The American Northwest. Arlington Heights, Ill.: Forum Press Inc., 1986.

Ellis, Barnes. "Indians sharply critical of leadership of Bureau of Indian Affairs." The Oregonian (Portland), Nov. 15, 1987.

Hogan, Dave. "Eviction of Indians from Columbia Fishing sites urged." The Oregonian (Portland), Oct. 27, 1987.

Koberstein, Paul. "Chinook put on endangered list." The Oregonian (Portland), April 18, 1992.

Leeson, Fred. "Ruling allows Indians to retain homes on river." The Oregonian (Portland), Sept. 6, 1991.

McAllister, Tom. "Gorge access issue boils." The Oregonian (Portland), June 1, 1989.

Monroe, Bill. "Tribal leaders pledge lobbying." The Oregonian (Portland), June 1, 1989.

Moulton, Gary, ed. The Journals of the Lewis and Clark Expedition. Vols. 5, 7. Lincoln: University of Nebraska Press, 1988, 1991. 
Oregon Journal (Portland), Jan. 6, 1934.

The Oregonian (Portland), Oct. 5, 1933; Apr. 20, 1971; Aug. 4, 1990.

Parman, Donald L. "Inconstant Advocacy: The Erosion of Indian Fishing Rights in The Pacific Northwest, 1933-1956." in The American Indian Past and Present, 4th ed., ed. Roger L. Nichols. New York: McGraw Hill, 1992.

Senior, Jeanie. "Fishing site evictions due fight." The Oregonian (Portland), Apr. 16, 1984.

. "Eviction notices at Columbia fishing sites upheld." The Oregonian (Portland), Apr. 25, 1986. 1989.

"Columbia Fishing Sites to be Shared." The Oregonian (Portland), May 26,

. "Law on fishing sites provokes controversy." The Oregonian (Portland), Aug. 4, 1989.

Taylor, Theodore W. The Bureau of Indian Affairs. Boulder, Colo.: Westview Press, 1984.

Ulrich, Roberta. "Indians will get fishing sites, but for what?" The Oregonian (Portland), Nov. 18, 1995.

and Alan Ota. "Congress stamps timber harvest cutback." The Oregonian (Portland), Oct. 28, 1990.

United Press, no title, Washington, D.C., Mar. 2, 1945.

Wilkinson, Charles F. American Indians, Time and the Law. New Haven: Yale University Press, 1987.

Willingham, William. Army Engineers and the Development of Oregon. Portland: U.S. Army Corps of Engineers, 1983.

. Power in the Wilderness. Portland: U.S. Army Corps of Engineers, 1987. 


\section{Documents}

Celilo Fish Committee. Minutes. June 7, 1939; Feb. 23, 1942; Apr. 4, 1945; Apr. 1, 1947; Oct. 22, 1948; July 20, 1951. Record Group 75. Bureau of Indian Affairs, Portland Area office, field agent The Dalles, general subject correspondence 1939-53, 155 U, Box 12. National Archives - Pacific Northwest Region, Seattle.

Columbia River Inter-Tribal Fish Commission. Briefing Book on Indian In-Lieu Fishing Sites and Fisheries Law Enforcement on The Columbia River between Bonneville and McNary Dams. Prepared for Sen. Dan Evans, vice chairman, Senate Select Committee on Indian Affairs. 1988.

Confederated Tribes of the Umatilla Indian Reservation Board of Trustees. Resolution. June 13, 1961; Jan. 9, 1962; Mar. 12, 1963; Apr. 9, 1963; May 28, 1963. Record Group 75. Bureau of Indian Affairs, Portland area office. Tribal council minutes, ca. 1950-65. Box 1571. National Archives - Pacific Northwest Region, Seattle.

Confederated Tribes of the Umatilla Indian Reservation Fish Committee. Report. Dec. 27, 1961. Record Group 75. Bureau of Indian Affairs, Portland Area office. Tribal Council minutes, ca. 1950-65. Box 1571. National Archives - Pacific Northwest Region, Seattle.

Confederated Tribes of the Umatilla Indian Reservation vs. Howard Calloway. Final judgment. U.S. District Court for Oregon. Civil case No. 72-211. Aug. 17, 1973.

Gordon, George W. Report to the Commissioner of Indian Affairs. Jan. 19, 1889. From files of the Portland District, U.S. Army Corps of Engineers.

Minor, Rick, Kathryn Ann Toepel and Stephen Dow Beckham. Report No. 83: Archaeology in the Columbia Gorge. Heritage Research Associates (Eugene, Ore.) 1989.

Palmer, Joel. Proceedings of the Wasco Council, Oregon Supt. \#436. Dayton, Oregon Territory. To George W. Manypenny, Commissioner of the Indian Office. July 9, 1855. Copy from files of the Portland District, U.S. Army Corps of Engineers.

Sohappy, David et al vs. Donald Hodel et al. Second amended complaint. Civil case No. 86-715-JU, U.S. District Court for Oregon. Oct. 23, 1986.

Swindell, Edward G., Jr. Report on Source, Nature and Extent of the Fishing, Hunting and Miscellaneous Related Rights of Certain Indian Tribes in Washington and 
Oregon. U.S. Department of Interior, Office of Indian Affairs, Division of Forestry and Grazing, Los Angeles. July 1942.

Treaty with the Wallawalla, Cayuse, Etc. 1855. Treaty with the Yakima (spelled Yakama in the preamble), 1855. Treaty with the Nez Perces, 1855 . Treaty with the Tribes of Middle Oregon, 1855. Copies obtained from files of the Columbia River Inter-Tribal Fish Commission, Portland.

United States of America vs. Rogers Logging Co. Complaint. U.S. District Court, Western District of Washington, Southern Division. Tacoma. No. 1114. Record Group 75. Bureau of Indian Affairs, Portland Area office, field agent The Dalles. General subject correspondence 1939-53. 155 U. Box 12. National Archives Pacific Northwest Region, Seattle.

U.S. Army Corps of Engineers. Columbia River Projects, Master Plan for Resources Use, Columbia River, Oregon and Washington. Working Document Development Suitability Analysis of Critical Management Units. Portland District, Corps of Engineers. Dec. 1990.

U. S. Army Corps of Engineers. Final Phase Two Evaluation Report and Finding of No Significant Impact/Environmental Assessment, Columbia River Treaty Fishing Access Sites and Technical Appendecis. Prepared by Portland District, U.S. Army Corps of Engineers. April 1995.

U.S. Army Corps of Engineers. Rules. Undated. Portland District files.

U.S. Congress. House. Appropriations Subcommittee on the Interior. Testimony of Melvin R. Sampson. Mar. 2, 1988.

U.S. Congress. House. Rivers and Harbors Report. Document 531. May 17, 1950. From files of Portland District, Army Corps of Engineers.

U.S. Congress. House. Rivers and Harbors Construction. Chapter 19 (part), Public Law 14. 79th Congress. 1st session. March 1945. From files of the Portland District, Army Corps of Engineers.

U.S. Congress. Senate. Columbia River Treaty Fishing Access Sites. 100th Congress, 2nd session, Title IV, Public Law 100-581 and fact sheet. Nov. 1, 1988. From the files of Sen. Brock Adams. 
U.S. Congress. Senate Select Committee on Indian Affairs. Report No. 100-577, to accompany H.R. 2677 Procedures for Review of Tribal Constitutions and Bylaws. 100th Congress. 2nd session. Sept. 30, 1988.

U.S. Congress. Senate. Select Committee on Indian Affairs. Testimony of Levi George and Delbert Frank, Sr. Apr. 19, 1988

Warm Springs Tribal Council. Resolutions. Nov. 5, 1948; Feb. 2, 1949. Record Group 75. Bureau of Indian Affairs, Portland Area office, field agent The Dalles. General subject correspondence 1939-53. 155 U. Box 12. National Archives Pacific Northwest Region. Seattle.

Warm Springs Tribal Council. Resolution. Sept. 1952. From files of Portland District, Army Corps of Engineers.

Yakima Tribal Council. Minutes. Oct. 16, 1942. Record Group 75. Bureau of Indian Affairs, Yakima Indian Agency. General subject files, 1925-67. Box 115. National Archives - Pacific Northwest Region, Seattle.

Yakima Tribal Council. Resolutions Aug. 9, 1939; Apr. 24, 1947; Feb. 8, 1949. Record Group 75. Bureau of Indian Affairs, Yakima Indian Agency. General subject files, 1925-67. Box 115. National Archives - Pacific Northwest Region, Seattle.

Yakima Tribal Council-Indian Fisherman Committee. Resolution. Oct. 23, 1942. Record Group 75. Bureau of Indian Affairs, Yakima Indian Agency. General subject files, 1925-67. Box 115. National Archives - Pacific Northwest Region, Seattle.

\section{Letters, Memos, Reports and Other Unpublished Material}

Allegre, Mike. Unpublished interview with the author. Nov. 17, 1995.

Graybeal, Nancy. Memo to forest supervisors. U.S. Forest Service, Region 6. July 6, 1992.

National Archives - Pacific Northwest Region, Seattle. Record Group 75. Bureau of Indian Affairs, Portland Area office. Tribal Council Minutes, ca. 1950-65. Boxes $1570,1571,1574$. 
Field Agent, The Dalles, Ore. General Subject Correspondence, 1939-53. 099-155 A-D, Box 9. Also $155 \mathrm{E}-\mathrm{K}$, Box 10. Also $155 \mathrm{~K}-\mathrm{S}$, Box 11. Also 1939-63. 155 U, Box 12. 155 E-K, Box 10. Yakima Indian Agency. General Subject Files, 1925-1967. 036.1-052, Boxes 114, 115.

. Yakima Indian Agency, Correspondence of Field Agent, The Dalles, Ore., 003-000. 1939-1949. Box 110.

Swindell, Edward G., Jr. Letter to Commissioner of Indian Affairs. U.S. Forest Service files, Region 6. Portland. Aug. 26, 1942.

U.S. Army Corps of Engineers. Unlabeled files in Portland District Office. 